University of New Hampshire

University of New Hampshire Scholars' Repository

Earth Systems Research Center

Institute for the Study of Earth, Oceans, and

Space (EOS)

8-2019

\title{
New Hampshire Coastal Flood Risk Summary Part 1: Science
}

\author{
Cameron P. Wake \\ University of New Hampshire, Durham, cameron.wake@unh.edu \\ Jayne Knott \\ JFK Environmental Services LLC \\ Thomas Lippmann \\ University of New Hampshire - Main Campus, t.lippmann@unh.edu \\ Mary D. Stampone \\ University of New Hampshire, Durham, mary.stampone@unh.edu \\ Thomas P. Ballestero \\ University of New Hampshire, Durham, tom.ballestero@unh.edu
}

See next page for additional authors

Follow this and additional works at: https://scholars.unh.edu/ersc

\section{Comments}

This document was funded, in part, by the National Oceanic and Atmospheric Administration Office for Coastal Management under the Coastal Zone Management Act in conjunction with the New Hampshire Department of Environmental Services (NHDES) Coastal Program.

\section{Recommended Citation}

Wake, C., Knott, J., Lippmann, T., Stampone, M., Ballestero, T., Bjerklie, D., Burakowski, E., Glidden, S., Hosseini-Shakib, I., Jacobs, J. (2019). New Hampshire Coastal Flood Risk Summary - Part I: Science. Prepared for the New Hampshire Coastal Flood Risk Science and Technical Advisory Panel. Report published by the University of New Hampshire, Durham, $\mathrm{NH}$.

This Report is brought to you for free and open access by the Institute for the Study of Earth, Oceans, and Space (EOS) at University of New Hampshire Scholars' Repository. It has been accepted for inclusion in Earth Systems Research Center by an authorized administrator of University of New Hampshire Scholars' Repository. For more information, please contact Scholarly.Communication@unh.edu. 


\section{Authors}

Cameron P. Wake, Jayne Knott, Thomas Lippmann, Mary D. Stampone, Thomas P. Ballestero, David Bjerklle, Elizabeth Burakowski, Stanley J. Glidden, Iman Hosseini-Shakib, and Jennifer M. Jacobs 


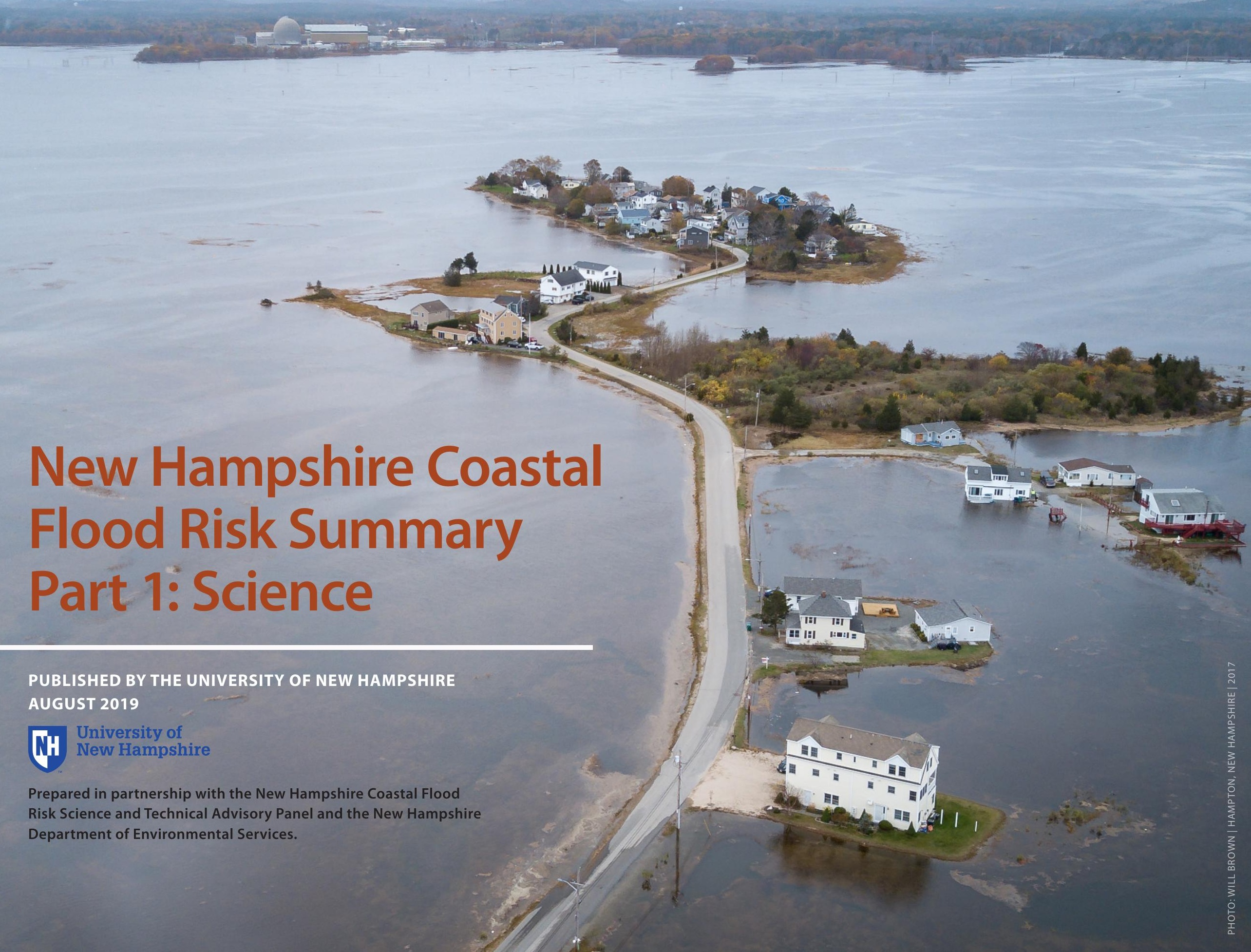


This report was completed in fulfillment of: RSA 483-B:22 Coastal and Great Bay Region Reports. The commissioner of the department of environmental services shall convene representatives of the department of transportation, the division of homeland security and emergency management, the office of strategic initiatives, and other agencies as he or she deems appropriate, at least every five years, commencing July 1, 2019 to supervise an updating of storm surge, sea-level rise, precipitation, and other relevant projections recommended in the coastal risks and hazards commission 2014 report "SeaLevel Rise, Storm Surges, and Extreme Precipitation in Coastal New Hampshire: Analysis of Past and Projected Trends." This report shall be distributed to all state agencies, municipalities in the coastal and Great Bay region, the governor, the speaker of the house of representatives, the president of the senate and the chairs of the house and senate committees with jurisdiction over issues related to such projections.

\section{SUGGESTED CITATION}

Wake, C., Knott, J., Lippmann, T., Stampone, M., Ballestero, T., Bjerklie, D., Burakowski, E., Glidden, S., Hosseini-Shakib, I., Jacobs, J. (2019). New Hampshire Coastal Flood Risk Summary - Part I: Science. Prepared for the New Hampshire Coastal Flood Risk Science and Technical Advisory Panel. Report published by the University of New Hampshire, Durham, NH.

\section{FUNDING AND ACKNOWLEDGEMENTS}

This document was funded, in part, by the National Oceanic and Atmospheric Administration Office for Coastal Management under the Coastal Zone Management Act in conjunction with the New Hampshire Department of Environmental Services (NHDES) Coastal Program. The authors gratefully acknowledge the organizational and technical support provided by Nathalie Morison and Kirsten Howard from the NHDES Coastal Program.

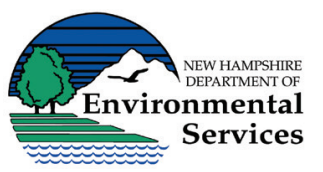

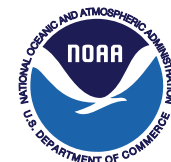




\section{CONTRIBUTORS}

\section{LEAD AUTHORS / SCIENCE ADVISORS}

Cameron Wake, Lead Coordinating Author, University of New Hampshire Jayne Knott, JFK Environmental Services LLC

Thomas Lippmann, University of New Hampshire

Mary Stampone, University of New Hampshire

Tom Ballestero, University of New Hampshire

David Bjerklie, U.S. Geological Survey

Elizabeth Burakowski, University of New Hampshire

Stanley Glidden, University of New Hampshire

Iman Hosseini-Shakib, University of New Hampshire

Jennifer Jacobs, University of New Hampshire

\section{EXTERNAL REVIEWERS}

Art DeGaetano, Northeast Regional Climate Center, Cornell University

Kerry A. Emanuel, Massachusetts Institute of Technology

Matthew Huber, Dept of Earth, Atmospheric, and Planetary Sciences,

Purdue University

Robert Kopp, Rutgers University

Denis R. LeBlanc, U.S. Geological Survey, New England Water Science Center

Peter Shanahan, HydroAnalysis, Inc., Acton, Massachusetts

William Sweet, National Oceanic and Atmospheric Administration

National Ocean Service

\section{STEERING COMMITTEE}

Steve Couture, NH Department of Environmental Services

Jennifer Gilbert, NH Office of Strategic Initiatives

Sherry Godlewski, NH Department of Environmental Services

Jennifer Harper, NH Division of Homeland Security and

Emergency Management

Ted Kupper, NH Department of Administrative Services

Julie LaBranche, Rockingham Planning Commission

Kyle Pimental, Strafford Regional Planning Commission

Cory Riley, NH Department of Fish and Game, Great Bay National Estuarine Research Reserve
Ann Scholz, NH Department of Transportation

Gail Wolek, NH Department of Natural and Cultural Resources

\section{TECHNICAL ADVISORS /}

\section{ADAPTATION PRACTITIONERS}

Members of the New Hampshire Coastal Adaptation Workgroup (NHCAW) and the State Environmental Resilience Group (SERG) were invited to provide input at Science and Technical Advisory Panel (STAP) meetings. Participants from these groups who provided technical advice included:

Ellie Baker, Horsley Witten

Tom Ballestero, University of New Hampshire

Jay Diener, Seabrook Hamptons Estuary Alliance

Elizabeth Durfee, EF Design \& Planning LLC

Stefanie Giallongo, NH Department of Environmental Services

Brianna Group, The Nature Conservancy

Adrianne Harrison, National Oceanic and Atmospheric Administration

Kevin Knuuti, Independent Consultant

Amy Lamb, NH Department of Natural and Cultural Resources

Abigail Lyon, Piscataqua Region Estuaries Partnership

Trevor Mattera, Piscataqua Region Estuaries Partnership

Steve Miller, Great Bay National Estuarine Research Reserve

Tom Morgan, Town of Seabrook

David Price, NH Department of Environmental Services

Todd Selig, Town of Durham

Sabrina Stanwood, NH Department of Natural and Cultural Resources

Pete Steckler, The Nature Conservancy

Amanda Stone, UNH Cooperative Extension

David Trubey, NH Department of Natural and Cultural Resources

Lisa Wise, UNH Cooperative Extension and NH Sea Grant

\section{PROJECT COORDINATORS}

Kirsten Howard, NH Department of Environmental Services

Nathalie Morison, NH Department of Environmental Services 


\section{CONTENTS}

1 Introduction. .................... 1

2 Changes Since 2014 Science and

Technical Advisory Panel (STAP) Report . . . . . . . . . . . . . 2

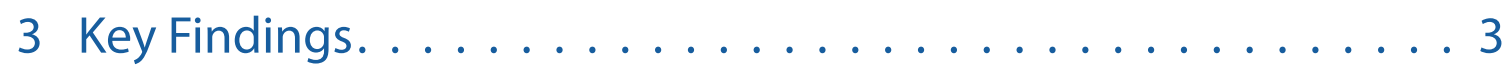

4 Relative Sea-Level Rise and High Tide Flooding . . . . . . . . . 4

5 Coastal Storms . . . . . . . . . . . . . . . . 21

6 Sea-Level Rise Induced Groundwater Rise . . . . . . . . . . . . 30

7 Precipitation. ................... . . 42

8 Freshwater Flooding. . . . . . . . . . . . . . . . . 54

9 References.......................661

Appendix A . . . . . . . . . . . . . . . . 74 


\section{INTRODUCTION}

Coastal flooding is already occurring in New Hampshire and is expected to increase in frequency and severity in the future. The State of New Hampshire Science and Technical Advisory Panel (STAP) report, initially developed for the New Hampshire Coastal Risk and Hazards Commission (CRHC) and released in 2014 (Kirshen et al., 2014), has provided guidance to state agencies and coastal municipalities for incorporating coastal flood risk projections into planning and other decisions. Following the release of the 2014 STAP report, the CRHC recommended that the State Legislature enact legislation authorizing a state agency to update the STAP report and provide planning guidance at least every five years. In 2016, the State Legislature enacted SB 374 (RSA 483-B:22), requiring the New Hampshire Department of Environmental Services (NHDES) to "convene representatives of the Department of Transportation, the Division of Homeland Security and Emergency Management, the [then] Office of Energy and Planning, and other agencies as [it] deems appropriate, at least every five years, commencing July 1, 2019 to supervise an updating of storm surge, sea-level rise, precipitation, and other relevant projections recommended in the [CRHC] 2014 [STAP] report."

This document, entitled New Hampshire Coastal Flood Risk Summary-Part 1: Science, was developed by a group of scientific advisors from the University of New Hampshire, supported and convened by the NHDES Coastal Program. The Science Advisors convened from November 2018 to June 2019 and met regularly during this period. The scope and content of this document was informed by members of the broader 2019 STAP, which was comprised of representatives from key state agencies, regional planning commissions, coastal municipalities, the University of New Hampshire, and other regional adaptation practitioners (see Contributors listed at the beginning of this document). This document was reviewed by STAP members, as well as an external panel of regional experts, and has been revised to reflect the input received. This document was accepted by the 2019 STAP Steering Committee on June 28, 2019.

\section{PURPOSE AND INTENDED USE}

The New Hampshire Coastal Flood Risk Summary - Part 1: Science provides a synthesis of the state of the science relevant to coastal flood risks in New Hampshire. Specifically, this document provides updated projections of sea-level rise, coastal storms, groundwater rise, precipitation, and freshwater flooding for coastal New Hampshire. This information is intended to serve as the scientific foundation for the companion New Hampshire Coastal Flood Risk Summary - Part II: Guidance for Using Scientific Projections and is intended to inform coastal land use planning and decision-making. 


\section{CHANGES SINCE 2014 SCIENCE AND TECHNICAL ADVISORY PANEL (STAP) REPORT}

This document summarizes recent scientific advances in our understanding of the various coastal flood risks that threaten the New Hampshire coast. Significant changes from the 2014 STAP report are summarized below.

- Relative sea-level rise (RSLR) projections for coastal New Hampshire are derived using a probabilistic approach and are presented out to 2150 for various greenhouse gas concentration scenarios (i.e., Representative Concentration Pathways) (see Section 4.5).

ש The 2050 RSLR projections for coastal New Hampshire under the stabilized greenhouse gas concentration scenario (RCP 4.5) are consistent with the 2017 National Climate Assessment (Sweet et al. 2017a, 2017b) and the 2014 STAP report (Kirshen et al., 2014) (Table 4.4). The 2100 RSLR projections are lower under a stabilized greenhouse gas concentration scenario (RCP 4.5) and very similar under the growing greenhouse gas concentration scenario (RCP 8.5) when compared to the 2017 National Climate Assessment and 2014 STAP report (Table 4.4).

- The contribution of Antarctic ice mass loss to RSLR becomes more important after 2050. Future assessments will need to take note of the changes in the rate of mass loss from Antarctica and the emerging science regarding Antarctic ice sheet instability.

- Under high RSLR scenarios, the flood and ebb tidal current magnitudes in the Great Bay Estuary could increase by $25 \%$ and in the Hampton-Seabrook estuary could increase by more than $85 \%$.
- Advancements in estimating storm surge along the New Hampshire coast have been realized since the 2014 STAP report. In particular, statistical analysis of storm surge has been conducted using ensembles of synthetic tropical and actual extra-tropical storms modeled over the North Atlantic (USACE, 2015). Annual exceedance probabilities can be computed from locations offshore and used to estimate the expected returnperiod surge height time series, a statistical representation of the likelihood that a surge of a given magnitude will occur in a certain period of time. These results can then be used to initialize other high resolution numerical wave, wind, and surge models with and without the presence of RSLR to better determine overall increases in water level for a particular event, the inundation and changes to current velocities that might occur, and the possible effects from climate change to a particular coastal or inland area.

- RSLR-induced groundwater rise is included for the first time in this update.

- Results from analysis of 29 new statistically downscaled Global Climate Model (GCM) simulations (based on 2017 National Climate Assessment Climate Science Special Report) for projections of future changes in precipitation are included.

- Potential changes in freshwater flooding are included for the first time in this update. 


\section{KEY FINDINGS}

Key findings related to projections of relative sea-level rise (RSLR), coastal storms (CS), groundwater rise (GWR), precipitation (PPT), and freshwater flooding (FWF) are summarized below. Additional detail and supporting information for each key finding is provided in Sections 4-8.

- SLR 1. Relative sea level (RSL) in New Hampshire is rising.

- SLR 2. The rate of ice mass loss from the Greenland and Antarctic ice sheets is accelerating, and land ice is now the primary contributor to sea-level rise.

- SLR 3. Relative sea level in coastal New Hampshire is projected to rise for centuries.

- CS 1. Inland and coastal impacts from storm surge in coastal New Hampshire will increase with RSLR.

- CS 2. Future storm surge increases as extreme storm intensity increases.

- CS 3. Current 100-year return period storm surge estimates vary.

- GWR 1. Coastal groundwater levels will rise with RSLR.

- GWR 2. Mean groundwater levels are projected to rise as a percentage of RSLR with the magnitude of groundwater rise decreasing with distance from the coast.
- GWR 3. The magnitude and extent of RSLR-induced groundwater rise is influenced by the coastal geometry, geology, and the proximity of freshwater discharge areas such as streams and freshwater wetlands.

- PPT 1. The magnitude of daily extreme precipitation events has increased by 15 - 38\% in New Hampshire's coastal watershed since the 1950 s.

- PPT 2. The frequency of extreme precipitation events is projected to increase over the course of the next several decades, especially in the springtime. This increase will likely result in an increased risk of flooding.

- PPT 3. The magnitude of future flooding will depend in part on how much the effective impervious surface changes in the coastal watershed due to development both inland and along the coast.

- FWF 1. Freshwater flooding in coastal New Hampshire has increased in magnitude and frequency.

- FWF 2. Freshwater flooding is expected to increase in the future. 


\section{RELATIVE SEA-LEVEL RISE AND HIGH TIDE FLOODING}

\subsection{KEY FINDINGS}

\section{SLR 1. Relative sea-level (RSL) in New Hampshire is rising.}

- Based on tide-gauge data from Seavey Island and Portland, Maine, RSL in coastal New Hampshire/southern Maine has risen approximately 7.5 - 8.0 inches $^{1}$ from 1912 - 2018 (Figure 4.4). New Hampshire's coastal property, public infrastructure, human health, public safety, economy, and natural resources are already experiencing the impacts of rising seas, including more extensive coastal flooding during nor'easters and high astronomical tides.

SLR 2. The rate of ice mass loss from the Greenland and Antarctic ice sheets is accelerating, and land ice is now the primary contributor to sea-level rise.

- The rate of ice mass loss from the Greenland and Antarctic ice sheets is increasing (Table 4.1; Figure 4.3, Box 4.2). The amount of sea-level rise that will occur after 2050 critically depends on complex dynamics driving ice loss from the Antarctic ice sheet.

SLR 3. Relative sea level in coastal New Hampshire is projected to rise for centuries.

- SLR 3.1. Prior to 2050 , there are only minor differences ( $<0.2$ feet) among different probabilistic relative sea-level rise (RSLR) projections due to differences in estimated mass loss from the Antarctic ice sheet and estimated global greenhouse gas concentrations (i.e., Representative Concentration Pathways (RCPs)) (Figure 4.6). The RCPs are described in Section 4.5. According to the Kopp et al. (2014) relative sea-level rise (RSLR) projections, coastal New Hampshire is likely to experience RSLR of 0.5 1.3 feet between 2000-2050 if global greenhouse gas concentrations stabilize (RCP 4.5; Table 4.2). There is a 1-in-100 chance that RSLR will exceed 2.0 feet by 2050 and a 1 -in-1000 chance that RSLR will exceed 2.9 feet by 2050 if global greenhouse gas concentrations stabilize (RCP 4.5).

Most measurements of sea-level rise in the scientific literature are provided in metric units (e.g. meters [m], millimeters [mm]). For the purpose of this report, most of the metric units have been translated into United States customary units (e.g., feet, inches). The one measure where the metric units have been retained in this report is for the annual rate of sea level rise, which is commonly translated into United States customary unis
reported in millimeters per year ( $\mathrm{mm} / \mathrm{yr}$ ).

2019 NH COASTAL FLOOD RISK SUMMARY PART I: SCIENCE | SECTION 4 | 4 
- SLR 3.2. After 2050, the Kopp et al. (2014) RSLR projections become increasingly dependent on global greenhouse gas concentrations and there is a much larger range in RSLR projections through 2150 (Table 4.2). For example, coastal New Hampshire is likely to experience RSLR of 1.0 - 2.9 feet by 2100 if greenhouse gas concentrations stabilize after 2050 (RCP 4.5); however, if greenhouse gas concentrations continue to grow throughout the $21^{\text {st }}$ century (RCP 8.5), coastal New Hampshire is likely to experience RSLR of 1.5 - 3.8 feet by 2100 . There is a 1-in-100 chance that RSLR will exceed 5.3 feet by 2100 if greenhouse gas concentrations stabilize (RCP 4.5), or 6.5 feet by 2100 if greenhouse gas concentrations continue to grow (RCP 8.5). There is a 1-in-1000 chance that RSLR will exceed 8.7 feet by 2100 if greenhouse gas concentrations stabilize (RCP 4.5), or 10.0 feet by 2100 if greenhouse gas concentrations continue to grow (RCP 8.5). Emerging research on the potential instability of the Antarctic ice sheet under growing greenhouse gas concentration scenarios highlights the potential for even more rapid RSLR after 2050 (Table 4.3).

- SLR 3.3. Sea levels will continue to rise for centuries. The rate of this continued rise will depend fundamentally on the rate of Antarctic ice sheet collapse.

\subsection{CHANGES FROM 2014 STAP REPORT}

- Future RSLR projections for coastal New Hampshire are derived using a probabilistic approach and are presented out to 2150 for four different greenhouse gas concentration scenarios (Section 4.5).

- The 2050 RSLR projections for coastal New Hampshire under the stabilized greenhouse gas concentration scenario (RCP 4.5) are consistent with the 2017 National Climate Assessment (Sweet et al. 2017a, b) and the 2014 STAP report (Kirshen et al., 2014)
(Table 4.4). The 2100 RSLR projections are lower under a stabilized greenhouse gas concentration scenario (RCP 4.5) and very similar under the growing greenhouse gas concentration scenario (RCP 8.5) when compared to the 2017 National Climate Assessment and 2014 STAP report (Table 4.4).

- The contribution of Antarctic ice mass loss to RSLR becomes more important after 2050. Future assessments will need to take note of the changes in the rate of mass loss from Antarctica and the emerging science regarding Antarctic ice sheet instability.

- Under high RSLR scenarios, the flood and ebb tidal current magnitudes in the Great Bay Estuary could increase by $25 \%$ and in the Hampton-Seabrook Estuary could increase by more than $85 \%$.

\subsection{UNDERSTANDING SEA-LEVEL RISE}

Changes in sea level occur over a broad range of spatial and temporal scales and these changes are driven by a variety of processes. A brief review was provided in the 2014 STAP report (Kirshen et al., 2014) and a discussion of the geographic variability of sea-level change is provided by Church et al. (2013) and Kopp et al. (2015). Additional detailed reviews of the processes that drive sea level and the resulting changes in sea level are provided by Milne et al. (2009), Church et al. (2013), Hall et al. (2016), Sweet et al. (2017), and Horton et al. (2018).

The rise in global mean sea level (GMSL; definition provided in Box 4.1) over the 20th Century was primarily due to the expansion of ocean water as it warms (thermal expansion), as well as the melting of mountain glaciers and resulting transfer of water to the ocean (Church et al., 2011). Changes in groundwater depletion and reservoir impoundment have also influenced GMSL (Gregory et al., 2013). 
Changes in relative sea level (RSL; definition provided in Box 4.1) can vary substantially from GMSL (Milne et al., 2009; Stammer et al., 2013; Kopp et al., 2015). Understanding local variability is critical for generating regional sea-level rise projections for effective coastal risk management (Horton et al., 2018). The spatial variability of RSL is driven by several different processes including: (1) vertical land movement associated with glacial isostatic adjustment (Peltier, 1998), tectonic activity, groundwater or fossil fuel withdrawal, and sediment compaction (Miller et al. 2013); (2) dynamical changes associated with change in ocean circulation and winds, and the distribution of heat and salt in the ocean (Yin, 2012, Bouttes et al., 2014); and (3) gravitational, rotational, and deformational (GRD) effects (i.e., perturbations in the Earth's gravitational field and crustal height) driven by the redistribution of mass between the cryosphere and the ocean (Mitrovica et al., 2009, 2011; Kopp et al., 2010; Horton et al., 2018).

\subsection{HISTORICAL SEA-LEVEL RISE}

Over the past 18,000 years, sea levels rose $400-450$ feet (Lambeck et al., 2014; Peltier et al., 2015; Bradley et al., 2016). Most of this sea-level rise occurred between 17,000 and 8,000 years ago, driven primarily by the disintegration and melting of large ice sheets. Over this 9,000-year period, GMSL rose on average approximately $12 \mathrm{~mm} /$ year; however, tropical sea-level rise reconstructions suggest that sea levels rose $25-43 \mathrm{~mm} /$ year due to rapid mass loss from large ice sheets during Meltwater Pulse $1 \mathrm{~A}$ that occurred over a 340 -year period from 14,650 to 14,310 years ago (Deschamps et al., 2012; Liu et al., 2016).

The rate of sea-level rise was reduced considerably around 8,000 years ago, associated with the end of the final phase of deglaciation in North America (Lambeck et al., 2014). Recent analysis of global sea level reconstructions over the past 3,000 years suggest that prior to the industrial revolution, sea level varied within a window of -2 to +6 inches, but with large RSL changes at particular locations (Kopp et al., 2016a; Kemp et al., 2018). The amount of sea-level rise since 1900 has historically been estimated based on a limited number of tide gauge records which provide a measure of the combined effects of GMSL rise (GMSLR) and RSL rise (RSLR). A variety of approaches have been used to estimate 20th century GMSL rise based on the

BOX 4.1: GLOBAL MEAN SEA LEVEL (GMSL) VERSUS RELATIVE SEA LEVEL (RSL) (AFTER HORTON ET AL., 2018)

Global mean sea level (GMSL): The areal mean of sea-surface height (as measured from satellites) or relative sea level (as measured with tide gauges) over the global ocean. Over the 20th century, GMSL was dominated by increases in ocean mass resulting from melting of land-based glaciers combined with thermal expansion of warming ocean water.

Relative sea level (RSL): The difference in elevation between the land and the sea surface at particular locations. RSL differs from GMSL due to processes operating on more regional scales, including vertical land motion, atmosphere/ocean dynamics, and changes in the height of the geoid (the gravitationally determined surface of the ocean in the absence of tides and ocean currents).

Additional concepts and terminology for sea level provided by Gregory et al. (2019) 


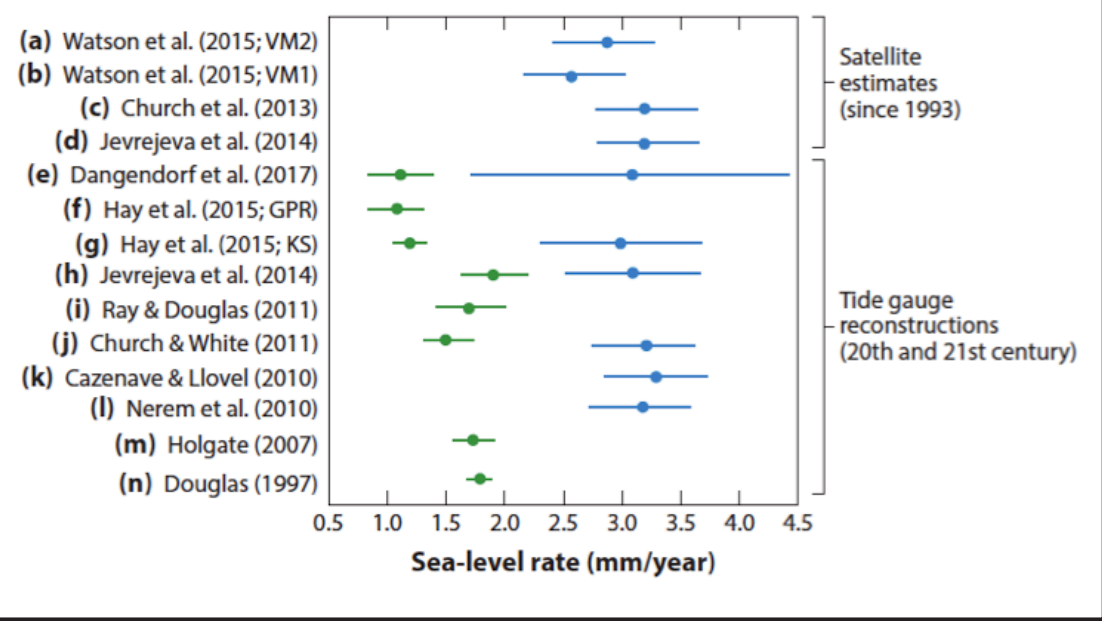

Figure 4.1. Rates of sea-level rise (dots) with one standard deviation (horizontal lines), over the twentieth century (green dots) and over the satellite altimetry era (blue dots) derived from tide-gauge and satellite altimetry observations. The period of time represented by each reconstruction are: (a) 1993-2014; (b) 1993-2014; (c) 1993-2010 (125); (d) 1993-2009; (e) 1901-1990, 1993-2012; (f) 1901-1990; (g) 1901-1990, 1993-2010; (h) 1900-1999, 1993-2009; (i) 1900-2009; (j) 1901-1990, 1993-2009; (k) 1992-2010; (l) 1993-2010; (m) 1904-2003; (n) 1880-1990. Figure from Horton et al. (2018).

tide gauge record with results ranging from 1.1-1.8 mm/yr over the 20th century (Horton et al., 2018; Figure 4.1). Since 1993, satellite altimeters have been used to map absolute sea level in the tropics and mid-latitudes, allowing for changes in sea surface to be estimated for most of the world's oceans. Calculating areaweighted averages in global sea surface heights derived from the satellite altimetry record indicates average GMSLR of $2.6-3.2 \mathrm{~mm} /$ yr since 1993 (Figure 4.1).

More recent analyses of the 25-year (1993 - 2018) satellite altimetry records conclude that GMSL has risen at a mean rate of $3.0 \pm 0.4 \mathrm{~mm} / \mathrm{yr}$ (Figure 4.2a; Nerem et al., 2018) or $3.1 \pm 0.3 \mathrm{~mm} /$ yr (Figure 4.2b; Cazenave et al., 2018) since 1993. From a statistical

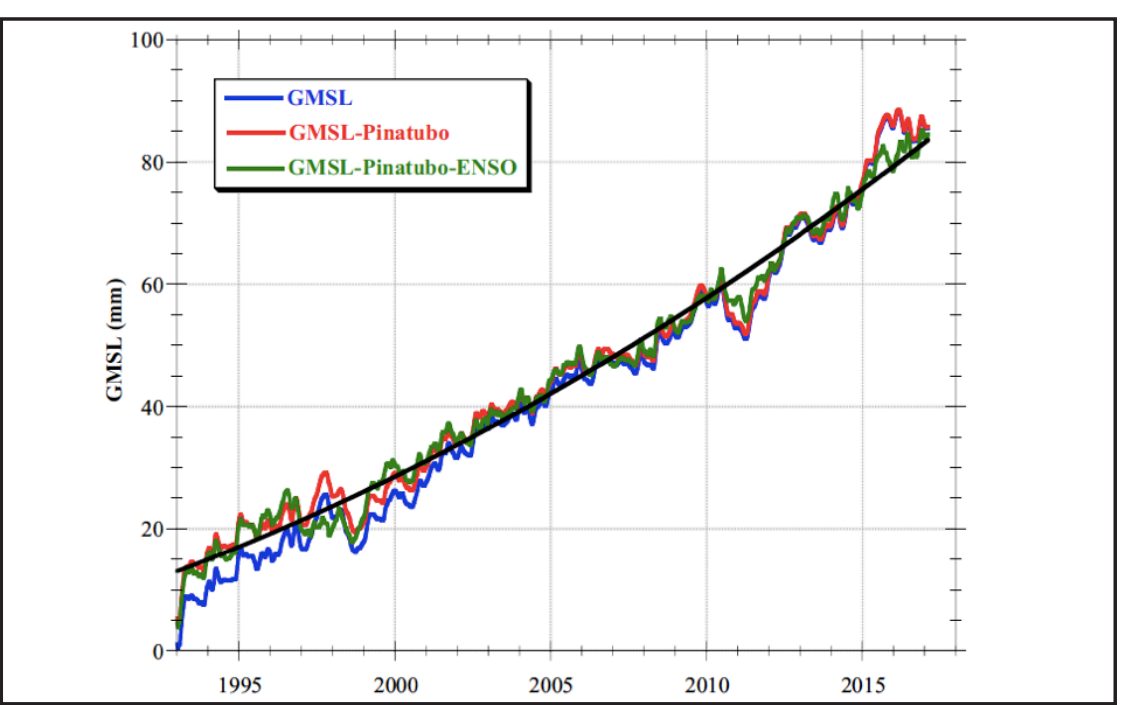

Figure 4.2a. Global mean sea level (GMSL) from the adjusted processing of TOPEX satellite measurements and after removing impacts of the eruption of Mount Pinatubo (red) the influence of ENSO (green). The black curve is the quadratic function fitted to the data. Figure from Nerem et al. (2018).

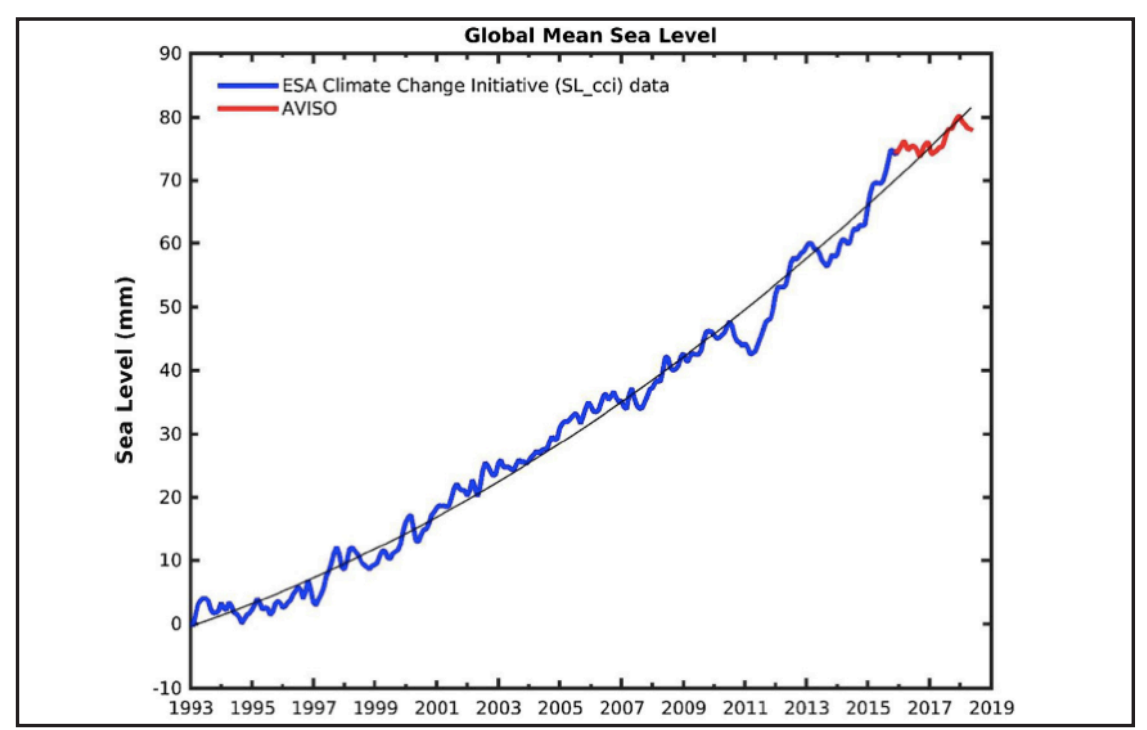

Figure 4.2b. Global mean sea level (GMSL) from satellite altimetry data from European Space Agency (January 1993 to December 2015) and AVISO (Jan 2016 to June 2018). A quadratic function fitted to the data is shown by the black line. Figure from Cazenave et al. (2018). 
analysis of satellite altimetry data, Chen et al. (2017) concluded that the rate of GMSLR increased to $3.3 \mathrm{~mm} / \mathrm{yr}$ by 2014. Analyses by both Nerem et al. (2018) and Cazanave et al. (2018) suggest that the rate of sea-level rise over the past 25 years has accelerated.

Though sea-level rise rates derived from satellite altimetry may appear to indicate a significant change from the longer 20th century trend, comparison of that record to the entire 20th century record demonstrates that is not necessarily the case. Rates of global sea-level rise similar to those derived from the satellite altimetry record occurred during the middle of the 20th century (Hay et al., 2015). Rhein et al. (2013) stated that while it is "technically correct that these multidecadal changes represent acceleration/deceleration of sea level, they should not be interpreted as change in the longer-term rate of sea-level rise, as a time-series longer than the variability is required to detect those trends" (See Figure 3.14 in Rhein et al., 2013). For a similar reason, the U.S. Army Corps of Engineers and the National Oceanic and Atmospheric Administration (NOAA) have concluded that a sea level record should be at least 40 years long in order to interpret a reasonable sea level change trend due to long-period ocean water level variations caused by Atlantic Multidecadal Oscillations and Pacific Decadal Oscillations, among other factors (USACE, 2009a). Note that Kopp (2013) presents rates of RSL rise in the mid-Atlantic region (which includes records from Seavey Island) in the 1930s that are similar to rates over the past 20 years.

\section{Contributions to Sea-Level Rise}

Recent analyses of satellite altimetry data and satellite derived gravity measurements have provided improved estimates of the contributions to recent GMSLR attributed to thermal expansion of ocean water and the melting of glaciers and ice caps (GIC), the Greenland ice sheet (GIS) and the Antarctic ice sheet (AIS), as well as how these contributions have changed over time (Cazenave et al., 2018; Table 4.1). From 1993-2015, the melting of land-based ice (from GIC, GIS, AIS) contributed approximately $45 \%$ to total GMSL $(1.38 \mathrm{~mm} / \mathrm{yr})$, slightly larger than the contribution from thermal expansion (1.30 mm/yr). However, the contribution of

Table 4.1. Contributions to global mean sea-level (GMSL) from 1993-2015. Source: Adapted from Cazenave et al. (2018).

\begin{tabular}{|c|c|c|c|c|}
\hline SLR COMPONENT & $\begin{array}{c}1993-2015 \\
\mathrm{~mm} / \mathrm{yr}\end{array}$ & $\begin{array}{c}1993-2015 \\
\text { Percent }\end{array}$ & $\begin{array}{c}2005-2015 \\
\mathrm{~mm} / \mathrm{yr}\end{array}$ & 1.30 \\
\hline Thermal expansion & 1.30 & $21 \%$ & 0.74 & $21 \%$ \\
\hline Glaciers & 0.65 & $16 \%$ & 0.76 & $22 \%$ \\
\hline Greenland & 0.48 & $8 \%$ & 0.42 & $12 \%$ \\
\hline Antarctica & 0.25 & $12 \%$ & 0.28 & $8 \%$ \\
\hline Residual & 0.37 & $100 \%$ & 3.50 & $100 \%$ \\
\hline TOTAL & 3.05 & & \\
\hline
\end{tabular}


melting land-based ice from $2005-2015$ accounts for $55 \%$ of the total GMSL, compared to $37 \%$ from thermal expansion. Analysis of satellite and in situ water column measurements also conclude that about two-thirds of GMSL since 2005 is the result of a shift in mass from land-based ice into the ocean, while about onethird is due to thermal expansion (Lueliette and Nerem, 2016; Figure 4.3). Recent analysis from Zemp et al. (2019) suggest that the sea-level rise contributions from glaciers and ice caps (not including Greenland and Antarctica) could be larger than what is reported in Table 4.1. Rignot et al. (2019) suggest that sea-level rise contributions from Antarctica could also be larger than what is reported in Table 4.1.

\section{Polar Ice Sheets}

There have been considerable advances in the understanding of the land-ice contribution to sea-level rise since the publication of the Intergovernmental Panel on Climate Change (IPCC) Fifth Assessment Report chapter on sea-level change (Church et al., 2013). Key findings and references are provided in several recent papers and reviews (e.g., Joughin et al., 2014; Velicogna et al. 2014; Khan et al., 2015; DeConto and Pollard, 2016; Forsberg et al., 2016; AMAP, 2017; Bamber et al., 2018, 2019; Moon et al., 2018; Rignot et al., 2019) and in a National Academy of Sciencessponsored lecture on sea-level rise (Rignot, 2019). This research has documented the acceleration of ice mass loss from both the Greenland and Antarctic ice sheets over the past two decades (Box 4.2). This mass loss is closely related to relatively warm, salty water at depths of $400-700 \mathrm{~m}$ that is melting the bottom of large ice shelves. Especially in Antarctica, several of the large outlet glaciers rest on bedrock that is below sea level and bedrock that slopes downward inland, on what is called a reverse slope. When a glacier that rests on a reverse slope begins to retreat, it becomes inherently unstable and retreat can occur rapidly. The recognition

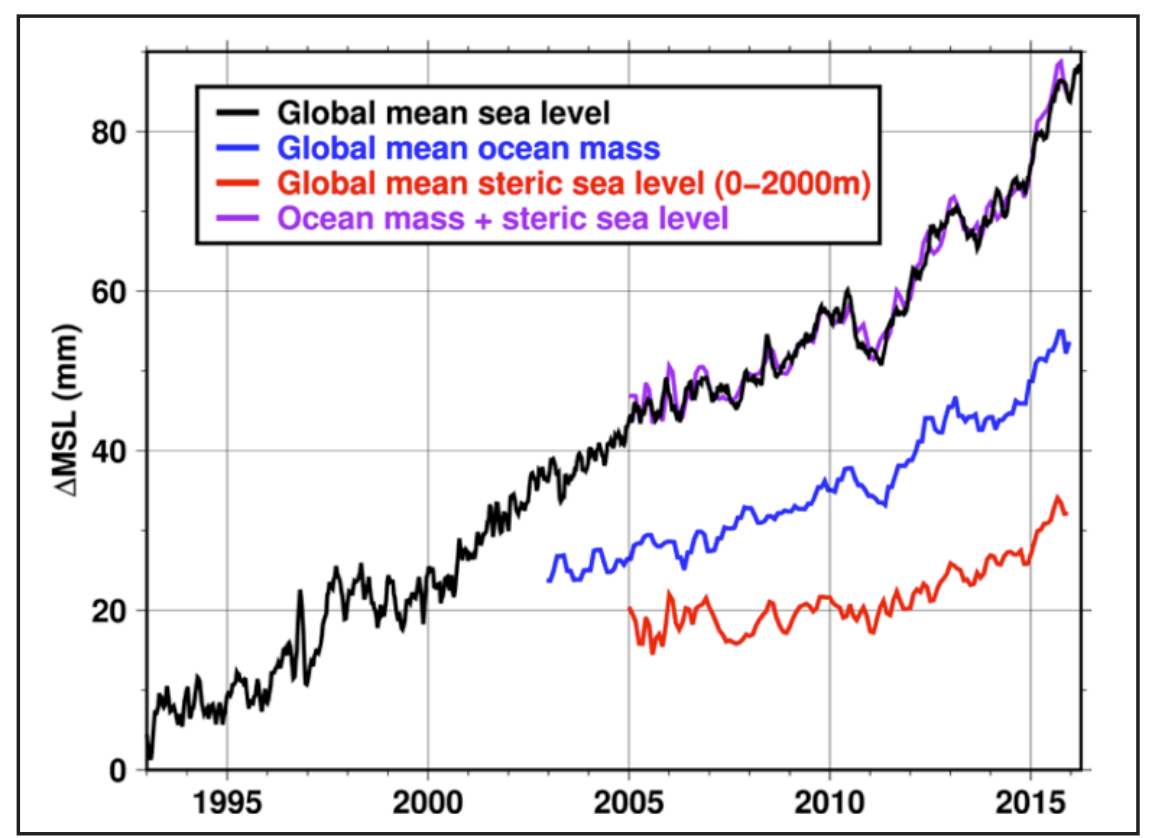

Figure 4.3. Contributions to GMSL from changes in ocean mass (measured by satellites) and changes in ocean volume (or steric changes, primarily form thermal expansion measured by in situ water column measurements) and comparison to GMSLR. Figure from Leuliette and Nerem (2016).

of marine ice sheet instability (MISI) was first identified by Hughes (1973) and Thomas et al. (1979). Several studies suggest that MISI is already happening in the Pine Island, Thwaites, Smith, and Kohler glaciers in West Antarctica (Favier et al., 2014, Joughin et al., 2014, Rignot et al., 2014).

\section{Ocean Dynamics}

Relative sea level (RSL) change can also be caused by changes in ocean-atmosphere dynamics over a wide range of spatial scales on annual to multi-decadal scales (Kopp, 2013; Horton et al., 2018). Ezer et al. (2013) and Yin and Goddard (2013) have noted that different RSL rise trends north and south of North Carolina are caused by variability in the Gulf Stream. A reduction in the strength of Atlantic Meridional Overturning Circulation (AMOC) - a trend documented in three recent studies (Rahmstorf et al., 


\section{BOX 4.2: ICE SHEETS AND SEA-LEVEL RISE: UNDERSTANDING THE NUMBERS}

- Antarctica contains an ice volume that translates to a sea level equivalent (SLE) of 188 feet (57.2 m). Source: Rignot et al., 2019.

- Greenland contains an ice volume that translates into sea level equivalent (SLE) of 24 feet (7.4 m). Source: Morlighem et al., 2017.

- From 2011 - 2014 mass loss from the Greenland ice sheet averaged $269 \pm 51$ billion tonnes / year. This rate of melting is double the estimated mass loss from the 1992 - 2011 average. Source: McMillan et al., 2016.

- From 2009 - 2017, mass loss from the Antarctic ice sheet averaged $252 \pm 26$ billion tonnes / year. This rate of melting is five times greater than the estimated mass loss from the 1989 - 2000 average. Source: Rignot et al., 2019.

- Melting 360 GT of land based ice raises sea level 1 mm. Source: Moon et al., 2018.

2015, Caesar et al., 2018; Thornalley et al., 2018) - could cause dynamical rise in sea level of 5-8 inches on the northeast coast of the United States (Yin 2012; Yin et al., 2009). However, recent dynamically driven changes in RSL along the US east coast appear to be related to the combined cumulative effects of the North Atlantic Oscillation and the El Nino/Southern Oscillation (Little et al., 2017; Valle-Levinson et al., 2017).

\section{Historical Sea-Level Rise in Coastal New Hampshire}

On a regional level, RSL has been rising on the New Hampshire coast for the past 10,000 years (Kelley et al., 1995; Ward and Adams, 2001). Direct measurements of RSLR have only been recorded at the Seavey Island tide gauge located close to the mouth of Piscataqua River since 1926. Based on this record over the period 1926 - 2001, RSL has risen $1.76 \pm 0.30 \mathrm{~mm} / \mathrm{yr}$ (Figure 4.4a). This rate of sea-level rise is greater than GMSLR over the twentieth century recently estimated by Hay et al. (2015) (1.2 \pm 0.2 $\mathrm{mm} / \mathrm{yr}$ ) and Dangendorf et al. (2017) (1.1 $\pm 0.3 \mathrm{~mm} / \mathrm{yr})$. Piecuch et al. (2018) estimate a median glacial isostatic adjustment of 0.4 $\mathrm{mm} / \mathrm{yr}$ at Seavey Island over the period 1900 - 2017. The rate of sea-level rise from the Portland Maine tide gauge from 1912 to 2018 (Figure 4.4b) is very similar to Seavey Island (1.88 \pm 0.14 $\mathrm{mm} / \mathrm{yr}$.), suggesting similar local processes are responsible for RSL operating in the coastal regions of southern Maine and New Hampshire over the 20th century. In contrast, the Boston tide gauge record from 1920 to 2018 (Figure 4.4c) shows a higher rate of sea-level rise of $2.83 \pm 0.15 \mathrm{~mm} / \mathrm{yr}$. This higher rate is most likely due to glacial isostatic adjustment (Kirshen et al., 2008; BRAG, 2016; Piecuch et al., 2018). A longer record of sea level in Boston Harbor extending back to 1825 is provided by Talke et al. (2018).

\subsection{RELATIVE SEA-LEVEL RISE PROJECTIONS}

\section{Projection Methods}

The method used to project RSLR for coastal New Hampshire in the 2014 STAP report (Kirshen et al., 2014) relied upon the approach used by the Third National Climate Assessment (Paris et al., 2012). That approach provided global sea-level rise scenarios that span 


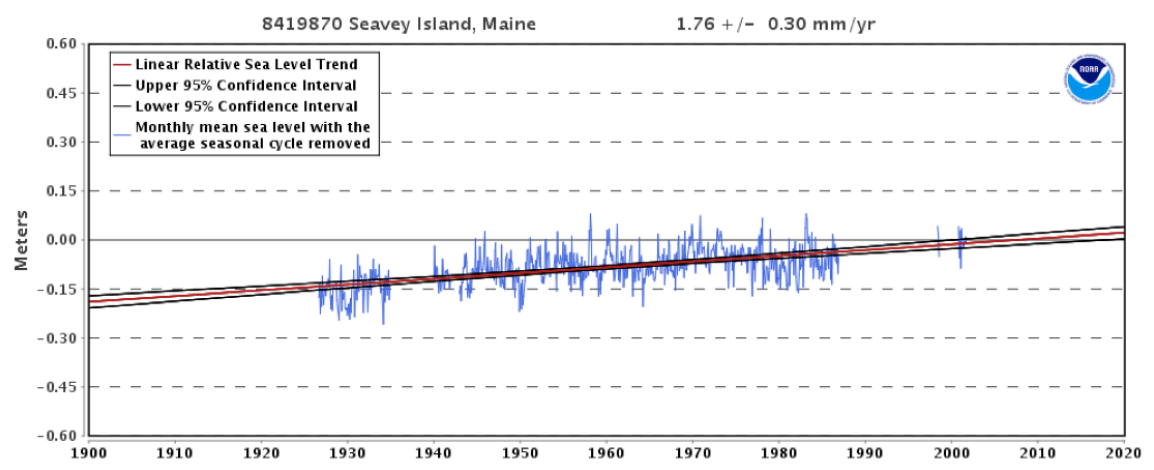

(a)

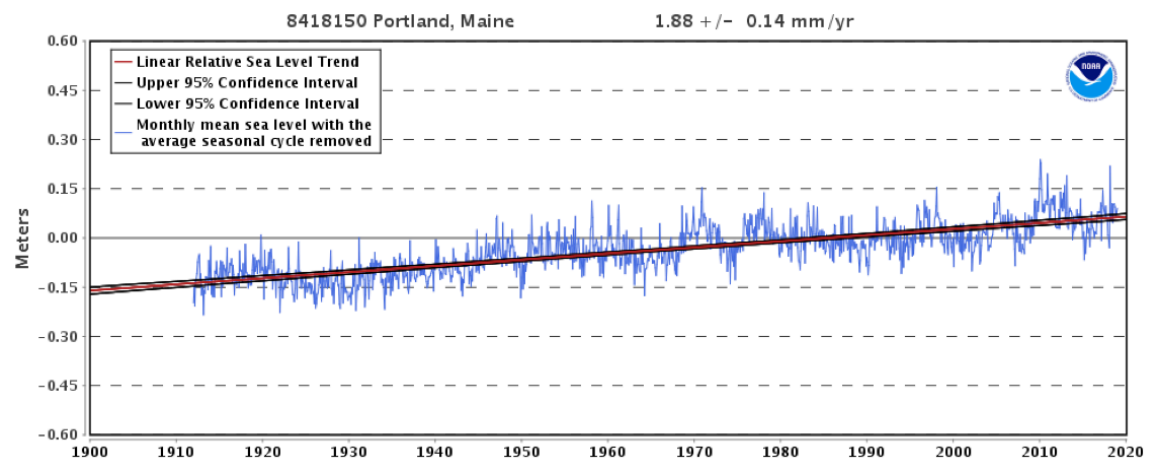

(b)

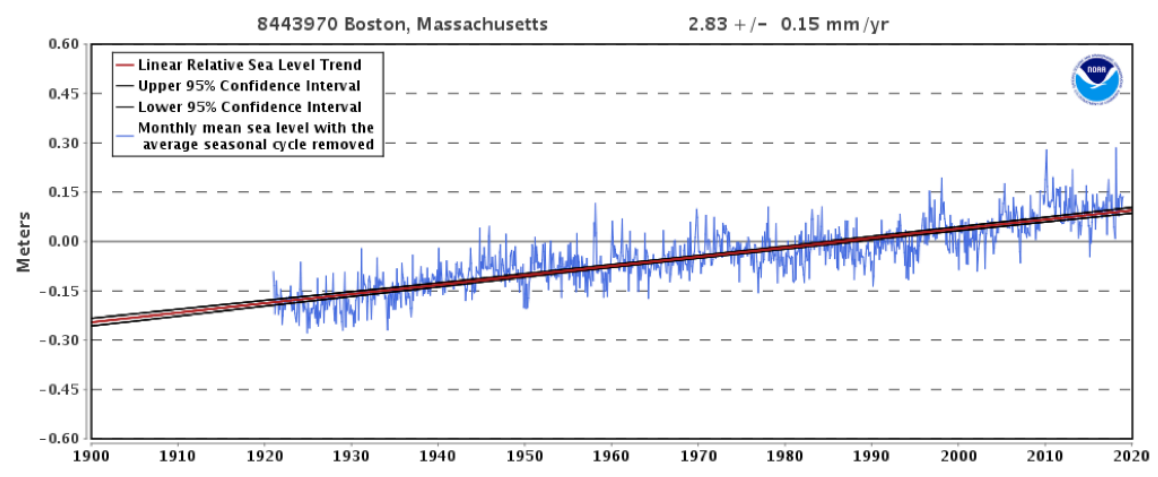

(c)

Figure 4.4. Tide gauge records from (a) Seavey Island, ME; (b) Portland, ME; (c) and Boston, MA. Source: NOAA (2019). a range of possible futures ( 0.6 to 6.6 feet by 2100 ) that reflect published estimates combined with uncertainties associated with the melting of the Greenland and Antarctic ice sheets. This projection approach was not designed to provide probabilistic projections of future sea-level rise, nor were the sea-level rise scenarios tied to greenhouse gas concentration scenarios.

Since publication of the Third National Climate Assessment, scientific projections of global sea-level rise have evolved (Horton et al., 2018), including the development of scenario-based probabilistic sea-level rise projections (e.g., Kopp et al., 2014) that provide decision makers with site specific information. Scenariobased probabilistic approaches explore the different processes that drive RSLR at specific locations, resulting in a probability distribution of RSLR based on a bottom-up accounting of different components for different climate change scenarios (Horton et al., 2018). For example, Kopp et al. (2014) include estimates of probability distribution functions for: the mass balance of the Greenland ice sheet, Antarctic ice sheet, and smaller glaciers and ice caps; different patterns of global sea-level rise caused by land ice mass loss; oceanographic processes (thermal expansion and large-scale dynamic effects), land water storage (including changes in fresh water stored in reservoirs and ground water depletion); and glacial isostatic adjustment and tectonics. These probability distribution functions are developed for each of the Representative Concentration Pathway (RCP) scenarios. The Kopp et al. (2014) scenario-based probabilistic framework was used for the Fourth National Climate Assessment (Sweet et al., 2017) and has also been used in several recent state and local sea-level rise assessments around the country, including New York City (Horton et al., 2015), North Olympic Peninsula, Washington (Petersen et al., 2015), City of Boston, Massachusetts (BRAG, 2016), State of New Jersey (Kopp et al., 2016b), State of California (Griggs et al., 
2017), State of Delaware (Callahan et al., 2017), State of Maryland (Boesch et al. 2018), State of Oregon (Dalton et al. 2017), and State of Washington (Miller et al., 2018). There are, however, limitations in using scenario-based probabilistic sea-level rise projections (see Box 4.3). For example, Behar et al., (2017) note that ". . . users of Bayesian probabilistic projections must understand how estimated Bayesian probabilities differ from the frequentist probabilities commonly used by decision makers, such as flood risk analysis around storm return periods (e.g., $1 \%$ annual chance event)." A detailed comparison of Bayesian and frequentists statistical approaches is provided in Samaniego (2010).

To establish science-based RLSR projections for coastal New Hampshire, we use the scenario-based probabilistic projections originally described in Kopp et al. (2014) (here referred to as K14;

\section{BOX 4.3: DESCRIPTION OF BAYESIAN AND FREQUENTIST PROBABILITIES}

Probabilistic projections of sea-level rise included in this document, based on Kopp et al., 2014, represent best available science. However, it is important to understand how these projections are developed and recognize that they serve as a guide for decision makers to understand current knowledge rather than as precise predictions of future conditions. As with all climate change projections, methodologies will continue to evolve over time as scientific knowledge and modeling capabilities improve.

Bayesian Probabilities: Scientific statements about the probability or likelihood of different future pathways, such as those made by probabilistic sea-level rise projections or by the Intergovernmental Panel on Climate Change, are examples of Bayesian probabilities. Bayesian probabilities are based upon a synthesis of multiple lines of evidence and represent an assessment of the strength of the observational, modeling, and theoretical evidence supporting different future outcomes. Probabilistic projections differ from frequentist probabilities, as described below.

Frequentist Probabilities: Frequentist probabilities are based on the historical frequency of occurrence, such as those commonly seen in estimating disease rates or determining flood risk. For example, the $1 \%$ annual exceedance probability flood (or the $100-$ year flood) is a flood of a level that historically occurred in about 1 in 100 years.

A Bayesian probabilistic framework can support improved decision making and easily integrate lines of scientific evidence, but may under- or overestimate sea-level rise contributions beyond 2050 and could lead to confusion if decision makers are unclear about the difference between Bayesian and frequentist probabilities (Behar et al., 2017). Nonetheless, probabilistic projections represent consensus on the best available science for sea-level rise projections through 2150 . With continued advances in sealevel rise science, it is expected that probabilistic projections will change in the future. However, the evolving nature of sea-level rise projections does not merit taking a 'wait and see' approach. Acting now is critical to safeguard the people and resources of New Hampshire.

Source: Adapted from OPC, 2018. 
Table 4.2). The projections are based on the RCPs. The original K14 projections were subsequently updated (Kopp et al., 2017) to incorporate more rapid discharge of ice from marine based ice sheets in Antarctica, based on the marine ice cliff instability modeling described in Deconto and Pollard (2016) (subsequently referred to as DP16; Table 4.3). However, as noted by Edwards et al. (2019), the DP16 projections likely overestimate future contributions of ice loss from Antarctica to GMSLR (more detail provided below). Other expert judgments have suggested that projections of future GMSLR likely fall somewhere in between the projections provided by K14 and DP16 (Boesch et al., 2018).

The RSLR projections provided in Tables 4.2 and 4.3 are provided for several different probabilities. The baseline for the projections in Tables 4.2 and 4.3 is the year 2000, or more specifically, average relative sea level over 1991-2009. Note that these results represent just one way (as described by Kopp et al., 2014; 2017a) of estimating the probability of different RSLR for coastal New Hampshire. Alternative methods may yield different estimates of the probability of high-end outcomes.

Despite the uncertainties in future Antarctic ice sheet contributions to GMSLR and concerns regarding scenario-based probabilistic projections, there are several reasons to use the scenario-based probabilistic projections to assess future RSLR in coastal New Hampshire.

- Scenario-based probabilistic sea-level rise projections include central estimates (e.g., median and likely range) and lower probability outcomes, allowing for consideration of risk tolerance in coastal management decision making.

- Separate projections tied to specific greenhouse gas concentrations (RCPs) provide clear examples of how emissions reductions influence the amount of RSLR.
- The central projections of GMSLR by Kopp et al. (2014) are by design in close agreement with those of the IPCC (Church et al., 2013) and compare well with other published scenario-based probabilistic models (Horton et al., 2018).

- Projections of RSLR that incorporate contributions of global processes (transfer of mass from land based ice sheets and glaciers into the ocean and thermal expansion) and more regional processes (vertical land motion, fingerprints of landice melting, and regional ocean dynamics) are readily available for tide gauges around the world, including Seavey Island at the mouth of the Piscataqua River. Open-source code used to produce the projections are available online at https://github. com/bobkopp/LocalizeSL.

\section{Representative Concentration Pathways (RCP)}

The RSLR projections for coastal New Hampshire were developed based on four different global greenhouse gas concentration scenarios, called Representative Concentration Pathways (RCPs), that span a range of radiative forcing (quantified in terms of watts per square meter $\mathrm{W} / \mathrm{m}^{2}$ ) in year 2100 of $2.6 \mathrm{~W} / \mathrm{m}^{2}$ (RCP 2.6), $4.5 \mathrm{~W} /$ $\mathrm{m}^{2}$ (RCP 4.5), 6.0 W/ $\mathrm{m}^{2}$ (RCP 6.0), and $8.5 \mathrm{~W} / \mathrm{m}^{2}$ (RCP 8.5) relative to pre-industrial values (Moss et al., 2010; van Vuuren et al., 2011). Each of the RCP scenarios resulted from collaboration among modelers, climate scientists, and emission inventory experts to update previous IPCC global emission scenarios (Nakicenvoic et al., 2000).

The RCPs were developed to represent a broad range of climate outcomes, consistent with a range of different socioeconomic and policy futures, including a mitigation scenario that leads to very low forcing (RCP 2.6), two stabilization scenarios (RCP 4.5 and RCP 6.0), and one scenario with very high greenhouse gas emissions (RCP 8.5). Sea-level rise scenarios for RCP 6.0 are only provided to 2100 as only a few of the global climate model runs using RCP 6.0 
extend beyond 2100. A brief description of the four RCP scenarios is provided below and more detail on RCPs is provided in Moss et al. (2010) and van Vuuren et al. (2011).

- RCP 2.6: Carbon emissions start declining right away, and continue to decline through the century, eventually becoming net-negative in the last quarter of this century. This scenario requires substantial reduction in emissions, including use of bio-energy combined with carbon capture and storage. Global temperatures rise by $1.6^{\circ} \mathrm{C}\left(2.8^{\circ} \mathrm{F}\right)$ (likely range $\left.0.9-2.3^{\circ} \mathrm{C}\right)$ by 2100, compared to $1850-1900$.

- RCP 4.5: Carbon emissions begin to stabilize and then slowly decline after 2050 . Global temperatures rise by $2.4^{\circ} \mathrm{C}\left(4.3^{\circ} \mathrm{F}\right)$ (likely range $1.7-3.2^{\circ} \mathrm{C}$ ) by 2100 , compared to $1850-1900$.

- RCP 6.0: Carbon emissions stabilize in the latter half of the 21 st century. Global temperatures rise by $3.0^{\circ} \mathrm{C}\left(5.4^{\circ} \mathrm{F}\right)$ by 2100 , compared to 1850-1900.

- RCP 8.5: Carbon emissions continue to grow through the end of the century due to continued burning of fossil fuels and high population growth. Global temperatures rise by $4.3^{\circ} \mathrm{C}$ $\left(7.7^{\circ} \mathrm{F}\right.$ ) (likely range $3.2-5.4^{\circ} \mathrm{C}$ ) by 2100 , compared to 1850 1900. RCP 8.5 is often called "business as usual" because the observed increase in global carbon emissions over the past two decades are consistent with the RCP 8.5 scenario (Hayhoe et al., 2017; Le Quéré et al. 2018). Ritchie and Dowlatabadi $(2017 ; 2018)$ suggest that the rapid expansion of carbon emissions from coal associated with RCP 8.5 is not plausible because of key uncertainties associated with the long-term recoverable portion of coals reserves, especially later in the $21^{\text {st }}$ century. Conversely, based on long-run economic growth forecasts, Christensen et al. (2018) conclude that there is a 35\% probability the carbon dioxide concentrations will exceed the
RCP 8.5 scenario by 2100 . In addition, uncertainties related to terrestrial carbon sinks associated with future plant growth (Brienen et al., 2015; Hedin, 2015; Popkin, 2015) and permafrost feedbacks (MacDougall et al., 2012, Schuur et al., 2015) suggest that atmospheric carbon dioxide levels could approach RCP 8.5 levels even without a substantial increase in carbon emissions from coal or other fossil fuels. Thus, RCP 8.5 remains relevant because the temperature projections associated with RCP8.5 can occur via a variety of pathways, and ice sheets and ocean water respond to temperatures, not RCPs.

\section{Projected RSLR in Coastal New Hampshire}

There are many factors that need to be taken into consideration when selecting RSLR projections for use in coastal management decision-making. For the purposes of this summary report, the preferred RSLR projections for coastal New Hampshire from 2000 to 2050 are based on K14 for the RCP 4.5 scenario (Table 4.2; Figure 4.5). The RCP 4.5 scenario was selected for near-term RSLR for two reasons; it represents an intermediate estimate of atmospheric greenhouse gas concentrations and there is little difference $(<0.2$ feet) between the RSLR projections under the four different RCP scenarios prior to 2050 (Figure 4.6). The projected rate of mass loss from the Antarctic ice sheet for both K14 and DP16 only ramps up after 2050, resulting in almost no difference between K14 and DP16 projections up to 2050 (Figure 4.7). Given the similarities in projections between K14 and DP16 prior to 2050, $\mathrm{K} 14$ is used for near-term RSLR in order to maintain consistency and continuity since K14 is the preferred approach for long-term RSLR projections (see next paragraph). According to the K14 RSLR projections under RCP 4.5, coastal New Hampshire is likely to experience RSLR of 0.5 - 1.3 feet between 2000 and 2050 with RSLR more likely than not reaching 0.9 feet by 2050 (Table 4.2, Figure 4.5). There is a 1-in-100 chance that RSLR will exceed 2.0 
feet by 2050 , and a 1-in-1000 chance RSLR will exceed 2.9 feet by 2050, if global greenhouse gas concentrations stabilize (RCP 4.5).

For the purposes of this summary report, the preferred RSLR projections from 2050 to 2150 are also based on K14 and the RCP 4.5 scenario (Table 4.2; Figure 4.5). The RCP 4.5 scenario is preferred because it is an intermediate emission pathway and represents a somewhat optimistic perspective whereby global concentrations of greenhouse gases stabilize at current levels by the middle of the century and then begin to decline. The K14 projection was also chosen for longer-term RSLR because it represents a lower estimate of the rate at which the Antarctic ice sheet will lose mass in the future due to marine ice sheet instability (MISI) and there remains uncertainty regarding if and when marine ice cliff instability (MICI) described by Deconto and Pollard (2016) becomes an important process. It is critical that future coastal flood risk assessments fully review both changes in the rate of mass loss from Antarctica and the emerging science regarding Antarctic ice sheet instability when RSLR projections are updated.

After 2050, the Kopp et al. (2014) RSLR projections become increasingly dependent on global greenhouse gas concentrations (Table 4.2) and there is a much larger range in RSLR projections through 2150 (Figure 4.5). For example, coastal New Hampshire is likely to experience RSLR of 1.0 - 2.9 feet by 2100 if greenhouse gas concentrations stabilize after 2050 (RCP 4.5); however, if greenhouse gas concentrations continue to grow throughout the $21^{\text {st }}$ century (RCP 8.5), coastal New Hampshire is likely to experience RSLR of 1.5 - 3.8 feet by 2100 . There is a 1 -in-100 chance that RSLR will exceed 5.3 feet by 2100 if greenhouse gas concentrations stabilize (RCP 4.5), or 6.5 feet by 2100 if greenhouse gas concentrations continue to grow (RCP 8.5). There is a 1-in-1000 chance that RSLR will exceed 8.7 feet by 2100 if greenhouse gas concentrations stabilize (RCP 4.5), or 10.0 feet by 2100 if greenhouse gas concentrations continue to grow (RCP 8.5). Emerging research on the potential instability of the Antarctic ice sheet under growing greenhouse gas concentration scenarios highlights the potential for even more rapid RSLR after 2050 based on DP16 (Table 4.3).

The K14 likely 2050 RSLR projections for RCP 4.5 are similar to those provided in the Fourth National Climate Assessment (Sweet et al., 2017a, 2017b) and the "intermediate high"scenario based on Parris et al. (2012) that was used in the 2014 STAP report (Kirshen et al., 2014) (Table 4.4). The K14 likely 2100 RSLR projections for RCP 4.5 projections are lower than those presented in Sweet et al. (2017a, 2017b) and the Parris et al. (2012) "intermediate high" scenario. However, under RCP 8.5, the K14 likely 2100 RSLR projections are similar to the STAP 2014 intermediate high projections and the Sweet et al. (2017a, 2017b) intermediate projections (Table 4.4). Note that even under RCP 8.5 and K14, our likely RSLR projections are still lower that the intermediate-high projections of Sweet et al. (2017a, 2017b), emphasizing that our projections should be considered relatively conservative (i.e., low) estimates.

\section{The Role of Antarctica in Future Relative Sea-Level Rise}

Recent research by Shakun et al. (2018) suggests that land based ice in the East Antarctic Ice Sheet is relatively stable and has survived significant warm periods over the past eight million years. However, Wilson et al. (2018) find that marine based ice is relatively unstable and tends to disintegrate during recent interglacial periods.

In addition to marine ice shelf instability (MISI) discussed in Section 4.4, DeConto and Pollard (2016) added the concept of marine ice cliff instability $(\mathrm{MICl})$, a self-sustaining retreat of glaciers on reverse slopes and where the ice cliff is more than 300 feet above the ocean surface. As the ice shelf collapses, the ice 
Table 4.2. Projected local sea-level rise (in feet) estimates above 2000 levels for NH based on K14 and the Seavey Island tide-gauge.

\begin{tabular}{|c|c|c|c|c|c|c|c|}
\hline & & Central Estimate & Likely Range & 1-in-20 Chance & 1-in-100 Chance & 1-in-200 Chance & 1-in-1000 Chance \\
\hline Year & $\mathrm{RCP}$ & $\begin{array}{l}50 \% \text { probability SLR } \\
\text { meets or exceeds: }\end{array}$ & $\begin{array}{l}67 \% \text { probability SLR } \\
\text { is between: }\end{array}$ & $\begin{array}{l}5 \% \text { probability SLR } \\
\text { meets or exceeds: }\end{array}$ & $\begin{array}{l}\text { 1\% probability SLR } \\
\text { meets or exceeds: }\end{array}$ & $\begin{array}{l}0.5 \% \text { probability SLR } \\
\text { meets or exceeds: }\end{array}$ & $\begin{array}{l}0.1 \% \text { probability SLR } \\
\text { meets or exceeds: }\end{array}$ \\
\hline 2030 & $\mathrm{RCP} 4.5^{*}$ & 0.5 & $0.3-0.7$ & 0.9 & 1.0 & 1.1 & 1.3 \\
\hline 2100 & RCP 2.6 & 1.4 & $0.6-2.5$ & 3.4 & 5.0 & 5.8 & 8.6 \\
\hline 2100 & RCP 4.5 & 1.9 & $1.0-2.9$ & 3.8 & 5.3 & 6.2 & 8.7 \\
\hline 2100 & RCP 8.5 & 2.6 & $1.5-3.8$ & 4.9 & 6.5 & 7.5 & 10.0 \\
\hline 2150 & RCP 2.6 & 2.0 & $0.9-3.4$ & 5.1 & 8.6 & 10.7 & 17.0 \\
\hline 2150 & RCP 4.5 & 2.7 & $1.2-4.6$ & 6.4 & 9.9 & 11.7 & 18.1 \\
\hline 2150 & RCP $6.0^{* *}$ & N/A & N/A & $\mathrm{N} / \mathrm{A}$ & N/A & N/A & N/A \\
\hline 2150 & RCP 8.5 & 4.0 & $2.6-5.8$ & 7.6 & 11.4 & 13.4 & 19.9 \\
\hline
\end{tabular}

The color in the rows for RCP 4.5 corresponds to the colors shown in Figure 4.5

* The 2050 RSLR projections using the RCP 4.5 scenario are very similar to the projections using the RCP 2.6, RCP 6.0, and RCP 8.5 scenarios. See text and Figure 5 for additional explanation.

** Projections for RSL after 2100 are not available for RCP 6.0.

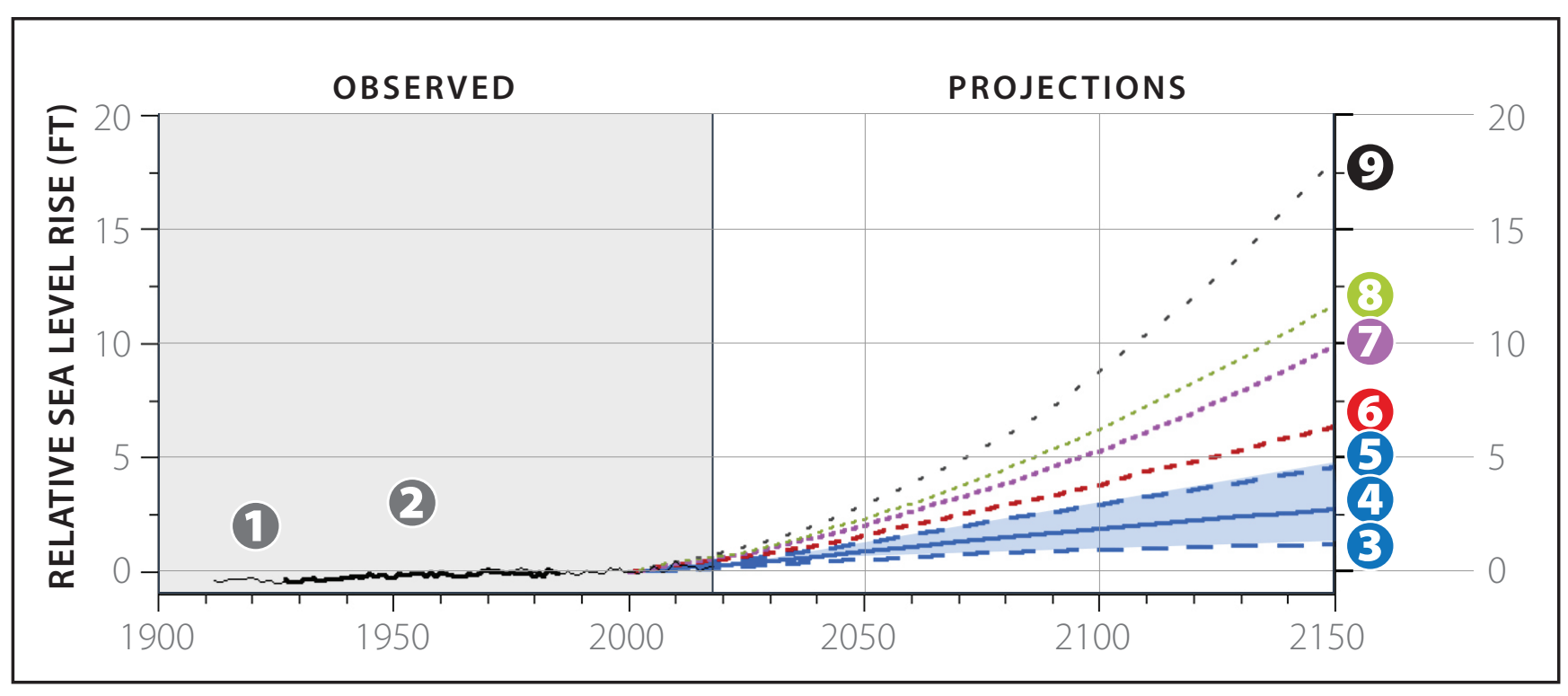

Figure 4.5. Observed and Projected Relative Sea-Level Rise for Seavey Island Tide Gauge K14 Projections | Stabilized Greenhouse Gas Concentrations (RCP 4.5).

(1) Historical data for Portland, ME

(1912-2018; thin black line)

2 Historical data for Seavey Island, ME

(1927-1986; thick black line)

(3) Lower end of "likely range"

4 Central estimate

5 Upper end of "likely range"

(6) 1-in-20 chance estimate

(7) 1-in-100 chance estimate

(8) 1-in-200 chance estimate

(9) 1 -in-1000 chance estimate 
Table 4.3. Projected local sea level rise (in feet) above 2000 levels out to 2150 for NH based on K14 and DP16 (see text for explanation) and the Seavey Island tide-gauge record.

\begin{tabular}{|c|c|c|c|c|c|c|c|c|c|c|c|}
\hline \multirow[t]{2}{*}{ Year } & \multirow[t]{2}{*}{ Scenario } & \multicolumn{2}{|c|}{$\begin{array}{l}\text { Central Estimate } \\
\text { 50\% probability } \\
\text { SLR meets or } \\
\text { exceeds: }\end{array}$} & \multicolumn{2}{|c|}{$\begin{array}{l}\text { Likely Range } \\
67 \% \text { probability } \\
\text { SLR is between: }\end{array}$} & \multicolumn{2}{|c|}{$\begin{array}{l}\text { 1-in-20 Chance } \\
5 \% \text { probability SLR } \\
\text { meets or exceeds: }\end{array}$} & \multicolumn{2}{|c|}{$\begin{array}{l}\text { 1-in-100 Chance } \\
1 \% \text { probability SLR } \\
\text { meets or exceeds: }\end{array}$} & \multicolumn{2}{|c|}{$\begin{array}{l}\text { 1-in-1000 Chance } \\
0.1 \% \text { probability } \\
\text { SLR meets or } \\
\text { exceeds: }\end{array}$} \\
\hline & & K14 & DP16 & K14 & DP16 & K14 & DP16 & K14 & DP16 & K14 & DP16 \\
\hline 2100 & RCP 2.6 & 1.4 & 1.7 & $0.6-2.5$ & $0.8-2.8$ & 3.4 & 3.5 & 5.0 & 4.3 & 8.6 & 5.0 \\
\hline 2100 & RCP 8.5 & 2.6 & 5.2 & $1.5-3.8$ & $3.6-7.5$ & 4.9 & 8.9 & 6.5 & 10.0 & 10.0 & 11.0 \\
\hline 2150 & RCP 2.6 & 2.0 & 2.4 & $0.9-3.4$ & $1.3-3.8$ & 5.1 & 5.0 & 8.6 & 5.7 & 17.0 & 6.3 \\
\hline 2150 & RCP 4.5 & 2.7 & 5.8 & $1.2-4.6$ & $3.8-9.4$ & 6.4 & 11.4 & 9.9 & 12.8 & 18.1 & 14.0 \\
\hline 2150 & RCP 6.0* & $\mathrm{N} / \mathrm{A}$ & $\mathrm{N} / \mathrm{A}$ & $\mathrm{N} / \mathrm{A}$ & $\mathrm{N} / \mathrm{A}$ & $\mathrm{N} / \mathrm{A}$ & $\mathrm{N} / \mathrm{A}$ & $\mathrm{N} / \mathrm{A}$ & $\mathrm{N} / \mathrm{A}$ & $\mathrm{N} / \mathrm{A}$ & N/A \\
\hline 2150 & RCP 8.5 & 4.0 & 14.4 & $2.6-5.8$ & $11.3-19.6$ & 7.6 & 21.0 & 11.4 & 22.1 & 19.9 & 23.2 \\
\hline
\end{tabular}

* Projections for RSL after 2100 are not available for RCP 6.0.

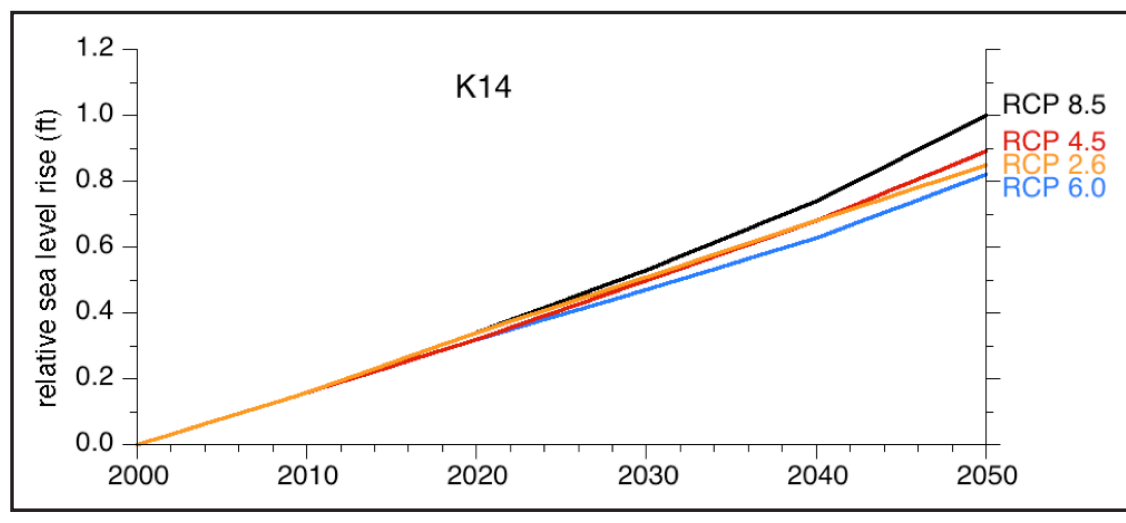

Figure 4.6. Median projected RSLR for coastal New Hampshire based on K14 for four different RCP scenarios. Note the minimal difference in RSLR out to 2050 between the four scenarios.

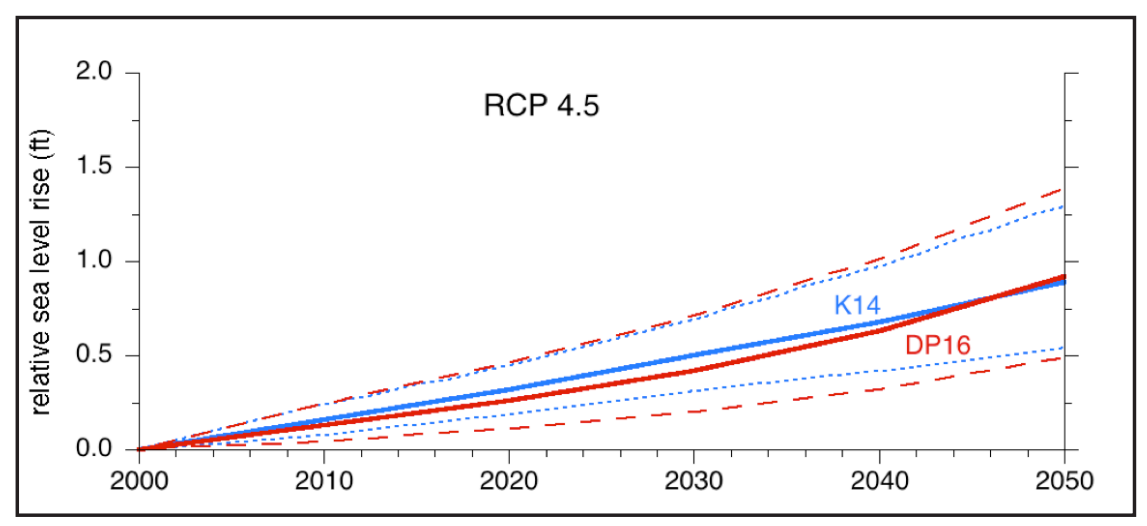

Figure 4.7. Projected RSLR for coastal New Hampshire based on K14 (blue) and DP16 (red) for the RCP 4.5 scenario. Solid blue and red lines represent the median projection. Blue dashed and red dotted lines represent the likely range. Note the minimal difference in median RSLR out to 2050 between K14 and DP16. 
cliff becomes taller (because of the reverse slope) and inherently more unstable, resulting in sustained ice loss. DeConto and Pollard (2016) concluded that under the RCP 8.5 scenario, these instabilities could result in an Antarctic ice contribution to GMSLR of more than three feet by 2100 and more than 50 feet by 2500 (Figure 4.8b). A comprehensive summary of the potential role of polar ice sheets in future sea-level rise is provided in Appendix 2 of the California sea-level rise assessment (Griggs et al., 2017).

The ice-sheet model used in the Deconto and Pollard (2016) GMSLR projections is driven by model output from the Community Climate System Model 4 (CCSM4). The CCSM4 simulations have been shown to exceed actual surface temperatures when run to simulate 20th century conditions (Gent et al., 2011). However, CCSM4 does have an equilibrium climate sensitivity (a measure of the temperature increase resulting from a doubling of atmospheric carbon dioxide concentration, and therefore a measure of how sensitive the model is to increase in atmospheric carbon dioxide) of $2.9^{\circ} \mathrm{C}$, which is slightly lower than the mean for the suite of global climate models used for the IPCC's Fifth Assessment Report (Flato et al., 2013).
Edwards et al. (2019) re-examine and estimate probability distributionfunctionsfortheDecontoandPollard(2016)projections using statistical techniques of uncertainty quantification. They find that the probability distributions for Antarctic contributions to sea-level rise by 2100 are skewed toward lower values (most likely value is 1.4 feet) compared to the higher value of 2.6 feet reported by Deconto and Pollard (2016) for the RCP 8.5 scenario. Of importance is that $\mathrm{MICl}$ introduces uncertainty regarding the upper limits of the Antarctic contribution to sea level in 2100 (see Table 2 in Edwards et al. (2019) for details). They also conclude "Most importantly, the presence or absence of $\mathrm{MICl}$ is by far the largest uncertainty in sea-level rise this century that could be quantified in this study". Note that the spread of high values listed in Table 4.2 (based on K14) does not rely upon $\mathrm{MICl}$ as a process. The processes driving rapid loss of ice from the Antarctic ice sheet will continue to be a focus of research and future assessments should pay close attention to this new knowledge.

The emerging research on the potential for marine ice cliff instability $(\mathrm{MICl})$ as a key process that increases the rate of collapse of the Antarctic ice sheet highlights the potential for more rapid

Table 4.4. Comparison of different relative sea-level rise projections for coastal New Hampshire in feet, relative to the year 2000 (except where noted).

\begin{tabular}{|c|c|c|c|c|c|}
\hline Year & $\begin{array}{c}\text { Parris et al. 2012** } \\
\text { Intermediate-High } \\
\text { Scenario }\end{array}$ & $\begin{array}{c}\text { Sweet et al. 2017b } \\
\text { Intermediate LR* }\end{array}$ & $\begin{array}{c}\text { Sweet et al. 2017b } \\
\text { Intermediate-High } \\
\text { LR* }\end{array}$ & $\begin{array}{c}\text { This Report: } \\
\text { RCP4.5, K14, LR* }\end{array}$ & $\begin{array}{c}\text { This Report: } \\
\text { RCP8.5, K14, LR* }\end{array}$ \\
\hline 2030 & N/A & $0.5-0.9$ & $1.1-1.3$ & $0.3-0.7$ & $0.3-0.8$ \\
\hline 2050 & 1.3 & $1.1-1.8$ & $1.4-2.5$ & $0.5-1.3$ & $0.6-1.4$ \\
\hline 2100 & 3.9 & $2.9-4.5$ & $4.4-6.9$ & $1.0-2.9$ & $1.5-3.8$ \\
\hline
\end{tabular}

* LR (= Likely Range): $67 \%$ probability that RSLR will fall within range provided in table.

** The Parris et al. (2012) sea-level rise estimates used in the Kirshen et al. (2014) STAP report represent values for global mean sea level rise (as opposed to RSLR) and are relative to 1992 (as opposed to 2000). 
sea-level rise after 2050 (Table 4.3 and Sweet et al., 2017a, b) compared to the $\mathrm{K} 14$ projections. The most significant variation between the K14 and DP16 projections (both shown in Table 4.3) results from significant differences in the assumed contribution of Antarctic ice. This difference is illustrated in Figure 4.8 which shows the various components of projected RSLR for both K14 and DP16 under the RCP 4.5 scenario. For K14, the contribution of the Antarctic ice sheet to RSLR is relatively modest. In DP16, before 2050, a warming atmosphere serves to increase snowfall in Antarctica and reduce GMSL by a few inches. However, after 2050, the contribution from the Antarctic ice sheet increases rapidly and becomes the single largest component of RSLR by 2100. Note that close attention should be paid to changes in the rate of mass loss from Antarctica and the emerging science regarding Antarctic ice sheet instability in future assessments.

\subsection{HIGH TIDE FLOODING AND TIDAL CURRENTS}

Due to RSLR over several decades, routine flooding causing minor impacts now occurs frequently in conjunction with astronomical high tides and/or typical storms, which decades ago would not have

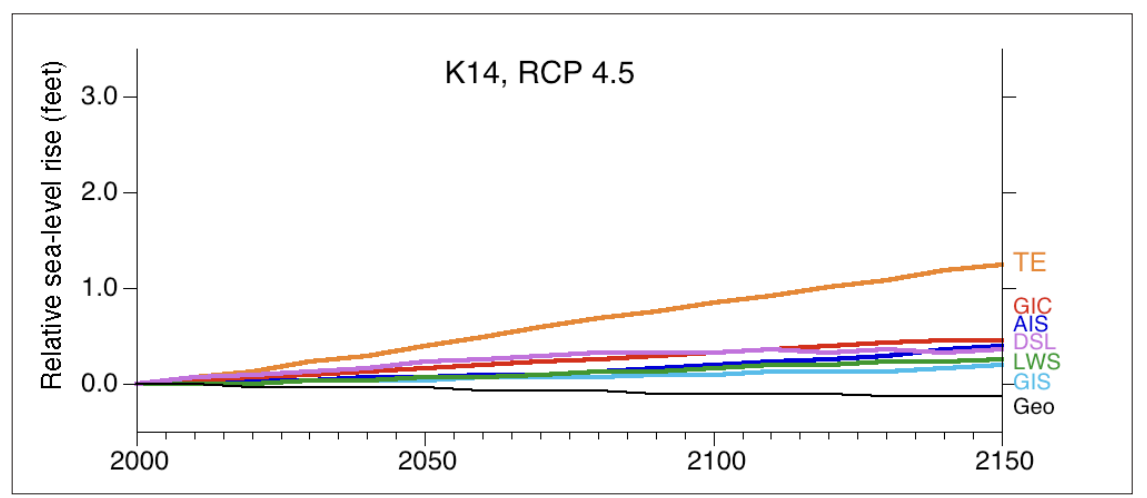

(a)

Figure 4.8. Components of median projected RSLR for coastal New Hampshire based on K14 (a) and DP16 (b) for the RCP 4.5 scenario. TE: thermal expansion, GIC: glaciers and ice caps, AIS: Antarctic ice sheet, DSL: dynamic sea level, LWS: land water storage, GIS: Greenland ice sheet, Geo: local vertical land motion. caused flooding (Sweet et al. 2018). Today, this high tide flooding occurs most notably during the monthly spring tides and during seasonal variations known as perigean tides (i.e., king tides) owing to annual variations in the proximity of the moon and sun to the earth (Ezer and Atkinson, 2014). High tide flooding can cause repetitive impacts, such as road closures, flooded storm drains, ground water rise, and damage to buildings and other infrastructure.

U.S. coastal tide gauge records show increases in high-tide flooding over the past few decades. For example, from 2000 to 2015 , high tide flood frequencies increased an average of $75 \%$ (from 3.4 to 6.0 days per year) along the Northeast U.S. coast (Sweet et al., 2018). The change in high tide flooding frequencies is explained primarily by RSLR; where RSLR is higher, the increase in the frequency of high tide flooding is higher. High tide is predicted to reach or exceed 10 feet above Mean Lower-Low Water a total of 56 times in 2019, not including storm conditions, according to the NOAA Tide Predictions for Hampton Harbor, New Hampshire. For reference, water levels of 10 feet, 11 feet, 12 feet, and 13 feet correspond with Hampton's threshold for taking action, minor

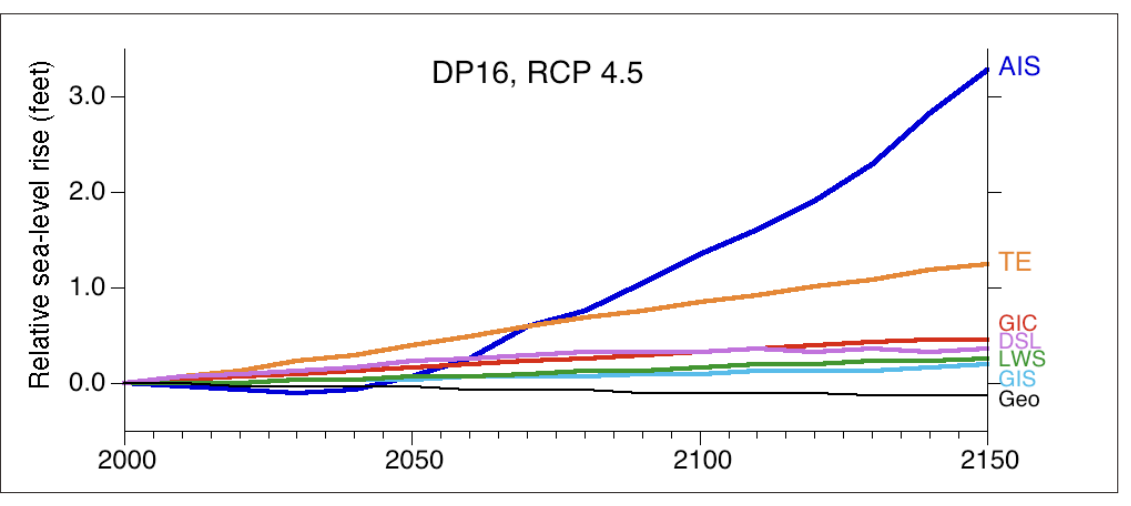

(b) 
flooding, moderate flooding, and major flooding, respectively, as defined by the National Weather Service. Limited data records exist to quantify high tide flood events in coastal New Hampshire; however, anecdotal evidence, such as the New Hampshire Coastal Adaptation Workgroup King Tide photo contests (NHCAW, 2019) and a recent ordinance allowing residents of the Town of Hampton to park their personal vehicles in any municipal parking lot when their property is expected to be flooding during tides greater than ten feet (Code of the Town of Hampton $\S 805-9 \mathrm{M}$ ) suggest high tide flooding may be increasing in frequency in low-lying areas. More research is needed to analyze historic tide gauge records at Hampton Harbor, New Hampshire in order to better understand any trends.

As RSL continues to rise in coastal New Hampshire, the frequency of high tide flooding will also increase (Sweet et al. 2018). For example, under the Intermediate GMSLR scenario of 3.3 feet (from Sweet et al., 2017b), high tide flood frequencies will increase to $132 \pm 26$ days per year by 2050 in the Northeast US, and will occur approximately daily by the end of the century. A separate analysis found that under a 3.9 feet of SLR scenario by the end of the century, $40 \%$ of all East Coast communities will be chronically inundated (defined as flooding that occurs 26 times per year) (Spanger-Siegfried et al., 2017).

RSLR also has the potential to alter the velocity of flood and ebb tidal currents due to changes in water volume moving through restricted estuarine systems. Models of the change in ebb and flood tidal currents under different RSLR scenarios are discussed in Chapter 5 and results are presented in Table 5.3. Overall, the depthaveraged flood and ebb current magnitudes down the center of the main channel in the Great Bay Estuary could increase by $25 \%$, and in the Hampton-Seabrook Estuary could increase by more than $85 \%$.

\subsection{SEA-LEVEL RISE EMERGING ISSUES}

As discussed in Section 4.5, changes in the rate of mass loss from Antarctica and the emerging science regarding Antarctic ice sheet instability in future assessments requires attention. Bamber et al. (2019) state "...severe limitations remain in the predictive capability of ice sheet models. As a consequence, the potential contributions of ice sheets remain the largest source of uncertainty in projecting future SLR."

While not reviewed in detail in this report, there is an area of active research exploring the role of amplified Arctic warming on climate in the mid-latitudes in general (Francis et al., 2017) and the eastern US in particular. This includes the link between warm Arctic episodes and severe winter weather in the eastern US (Cohen et al., 2018), a reduction in Arctic sea ice and an increase in atmospheric blocking that - for example - helped steer superstorm Sandy into New York (Greene et al., 2015), and links between a warming Arctic and a reduction in the strength of Atlantic Meridional Overturning Circulation (Rahmstorf et al. 2015, Caesar et al. 2018; Thornalley et al., 2018). As research on Arctic - mid-latitude climate linkages continues to grow, key findings should be included in future assessments.

One area of additional research should focus on the interaction among RSLR, storm surge, and heavy precipitation on flooding in the Great Bay Estuary. More detailed discussion of this topic is provided in Section 8.5. 


\section{COASTAL STORMS}

\subsection{KEY FINDINGS}

\section{CS 1. Inland and coastal impacts from storm surge in coastal New Hampshire will} increase with RSLR.

- CS 1.1. Model simulations of ensembles of extreme tropical and extratropical storms over the North Atlantic linked to high resolution numerical models of New Hampshire estuaries show that the inundation area and maximum ebb and flood tidal currents due to storm surge increase nonlinearly under RSLR.

- CS 1.2. The challenge of projecting future effects of storm surge and waves with and without RSLR is exacerbated by unknown changes to the topography (e.g., erosion of beaches, dunes, channels, and marshes) that will occur over the years leading up to future storm events. Accounting for sediment transport within models is necessary to account for continuous evolution of coastal bathymetry and shoreline geomorphology. These models can include strategies that implement, for example, conceptual coastal protection structures, green infrastructure, shoreline restoration, and beach nourishment.

\section{CS 2. Future storm surge increases as extreme storm intensity increases.}

There is broad agreement that anthropogenic factors have had an effect on the observed increase in storm activity, intensity, and frequency since the 1950s (Houser et al., 2014; Kossin et al., 2017). Strong correlation between sea surface temperature and increases in hurricane activity in Atlantic storm development regions suggests that future North Atlantic storms could become more intense and more frequent (Emanuel, 2007; Emanuel, 2013; Knutson et al., 2013), particularly in light of projected increases in sea surface temperature over the next century. Horton et al. (2015) estimates that the number of intense hurricanes, extreme hurricane winds, and hurricane precipitation are "more likely than not" to increase by the year 2080. Ignoring the possible effects of increasing extreme storm intensity and frequency could substantially underestimate the damages 
and risks associated with future storm impacts (Pielke et al., 2008). If extreme storms increase in intensity, then results from, for example, the North Atlantic Comprehensive Coastal Study (NACCS; USACE, 2015) would likely under-predict the maximum water level changes under extreme events for any given return period storm. Considering that damage effects from extreme storms increase substantially as storm intensity increases, the impacts on risk assessment could also be substantial, but large uncertainties in extreme storm projections over the next century make it difficult to confidently incorporate potential changes in storm properties into storm distributions for climate change impacts (Houser et al., 2014).

CS 3. Current 100-year return period storm surge estimates vary. Estimates of storm surge for the present-day 100-year return period vary. FEMA estimates about four feet (FEMA, 2005b; 2016), whereas the U.S. Army Corps of Engineers NACCS study estimates 5.3 feet. Both estimates are consistent with the 3.74 feet (with 95\% confidence interval ranging 3.3 - 4.9 feet) estimated from analysis of historical tide gauge data at Seavey Island (NOAA, 2019). As the NACCS study is the most well documented in terms of individual storm effect, it represents a reasonable estimate.

\subsection{CHANGES FROM 2014 STAP REPORT}

Advancements in estimating storm surge along the New Hampshire coast have been realized since the 2014 STAP report. In particular, statistical analysis of storm surge has been conducted using ensembles of synthetic tropical and actual extra-tropical storms modeled over the North Atlantic (USACE, 2015). Annual exceedance probabilities can be computed from locations offshore and used to estimate the expected returnperiod surge height time series, a statistical representation of the likelihood that a surge of a given magnitude will occur in a certain period of time. These results can then be used to initialize other high resolution numerical wave, wind, and surge models with and without the presence of RSLR to better determine overall increases in water level for a particular event, the inundation and changes to current velocities that might occur, and the possible effects from RSLR to a particular coastal or inland area.

\subsection{STORM SURGE IN NEW HAMPSHIRE}

The New Hampshire coastline is threatened by large storms that may be generated in both lower latitudes (tropical storms or hurricanes) and the North Atlantic (extratropical storms or nor'easters). These storms temporarily raise sea level due to several processes, including changes in atmospheric pressure (with 0.4 inches increase in sea level per one millibar decrease in atmospheric pressure), winds dependent on orientation and fetch that push water up against or away from the coastline (wind set-up), the speed of the storm which can interact with the bottom topography to amplify increases in water levels, and wave processes that push water up against the shoreline (wave set-up) and generate the to-and-fro motion of the swash at the water's edge (wave run-up). The impact of storm surge and waves depends on the timing of the storm with the tides. As RSL rises, inundation, erosion, and damage associated with storm surge and wave impacts are expected to worsen over the next century, with economic consequences felt by an increasing number of people and communities. The combined effects result in shortterm rise in sea level (storm surge) that may reach elevations that flood inland areas and overtop dunes and coastal barriers.

The effects of storm surge and sea-level rise on coastal communities and ecosystem services is difficult to project owing to the strong nonlinear behavior of tides, waves, and storm surge in shallow water. For example, simple bath-tub approaches used 
to project inundation do not consider the effects of sea level on tides, waves, and storm surge, or the effects of bottom dissipation or amplification on surge in shallow regions. The recognition that inundation and storm damage depends on how waves and surge propagate into shallow inlets, estuaries, and over land, as well as how currents move sediment and cause erosion of protective coastal barriers (like dunes) or salt marshes, results in highly uncertain projections offuture damagefrom storm surge. However, recent advancements have utilized coupled hydrodynamic, wave, and wind numerical models to better assess the effects of storms on water levels in the presence of sea-level rise.

\section{Modelled Storm Surge from the North Atlantic Comprehensive Coastal Study (NACCS)}

Storm surge along the North Atlantic coastline of the U.S. has been modeled by the U.S. Army Corps of Engineers and reported in the North Atlantic Comprehensive Coastal Study (NACCS; USACE, 2015). In the NACCS study, 1,050 synthetic tropical storms and 100 historical extratropical storms were simulated with numerical models implemented over a domain that extends across the North Atlantic Ocean and into the Gulf of Maine. These models included WAM (WAMDI Group, 1988), ADCIRC (Luettich, et al., 1992), and STWAVE (Smith, et al., 2001). The tropical storms were synthetically produced to span the ensemble of all statistics obtained from available recorded data of hurricanes occurring over the past 150 years, while the historical nor'easters are based on actual data for particular storms. Time series of water level elevation, winds, and wave statistics for any given storm scenario are saved at coastal ocean locations (so-called save points) along the U.S. eastern seaboard including offshore New Hampshire.

The time series of maximum storm surge can be used to create water level hazard curves for tropical storms, extratropical storms, and the combination of both at any NACCS model save point based on the annual exceedance probability (AEP), a statistical measure of the likelihood that a given surge will exceed a certain height. Figure 5.1 shows an example of the water level hazard curve for a particular location about seven miles in 33-foot water depth off the coast of New Hampshire near the Isles of Shoals (save point 2047). From these hazard curves, the expected return period storm for maximum storm surge can be estimated. For example, the 10-, 100-, and 1,000-year return period storms are represented by the $0.1,0.01$, and 0.001 AEP corresponding to the $10 \%, 1 \%$, and $0.1 \%$ exceedance level (Table 5.1 ). For example, the storm water level time series corresponding to the $1 \%$ exceedance level in Figure 5.1 has maximum storm surge of 5.3 feet. This value represents the storm surge that would occur at that location, but not necessarily at the shoreline or in the inlets and estuaries. The utility of knowing the surge offshore the coast lies in the ability to initialize other models that can propagate the

Table 5.1. Estimated NACCS return period (AEP) water levels from hazard curves offshore New Hampshire in 33 feet water depth. Source: USACE (2015).

\begin{tabular}{|c|c|c|c|c|}
\hline Return Period & 1-year & 10 -year & 100-year & 1000 -year \\
\hline (AEP) & $(1.0)$ & $(0.1)$ & $(0.01)$ & $(0.001)$ \\
\hline 33 feet water depth & 1 foot & 3.6 feet & 5.3 feet & 7.5 feet \\
\hline
\end{tabular}




\section{BOX 5.1: 100-YEAR RETURN PERIOD STORM SURGE}

- FEMA estimates about four feet for the 100-year return period storm surge at the mouth of the Piscataqua River (FEMA, 2005; NOAA Exceedance Probability Levels for Seavey Island, ME).

- Based on analysis of the North Atlantic Comprehensive Coastal Study (NACCS; USACE, 2015), the 100-year return period surge is about 5.3 feet.

- Considering the complexities involved in storm surge predictions, it is not surprising that the range of return period estimates varies relative to one another and to historical water level analysis. The estimate from the NACCS study is higher, but is considered a reasonable estimate for the 1\% Annual Exceedance Probability (or the 100-year return period) storm surge.

surge toward the coast and inland allowing for interactions with the topography (and possible amplification of the surge height at the land-sea boundary).

This 5.3 feet estimate is higher than the 4 feet estimates from FEMA (2005b) (based on analysis of a synthetic storm surge dataset generated by a computer model) and the 3.7 feet (95\% confidence interval of 3.3 - 4.9 feet) estimate from NOAA (2019) (based on analysis of tide gauge data from Seavey Island). Note that although the tide gauge analysis is appropriate for storm surge at the mouth of the estuary, maximum water levels along New Hampshire's open coast beaches during the storms is likely much higher owing to wave effects (set-up and run-up) and wind set-up directly against the shoreline.
Results from the NACCS are reported for model savepoints in very shallow water and in estuaries; however, the NACCS simulations are not applied to particular tidal cycles and have grids that are necessarily quite large owing to large computational expense in running the simulations. As a consequence, it is recommended to use NACCS save point data at locations on the continental shelf nearby locations of interest, and then use those data to initialize high resolution models that include tides and details of the shallow water bathymetry, shoreline, dunes, inlets, and estuaries (Shaw et al., 2016). The selected storm event can be added to predicted tidal time-series at phases that synchronize

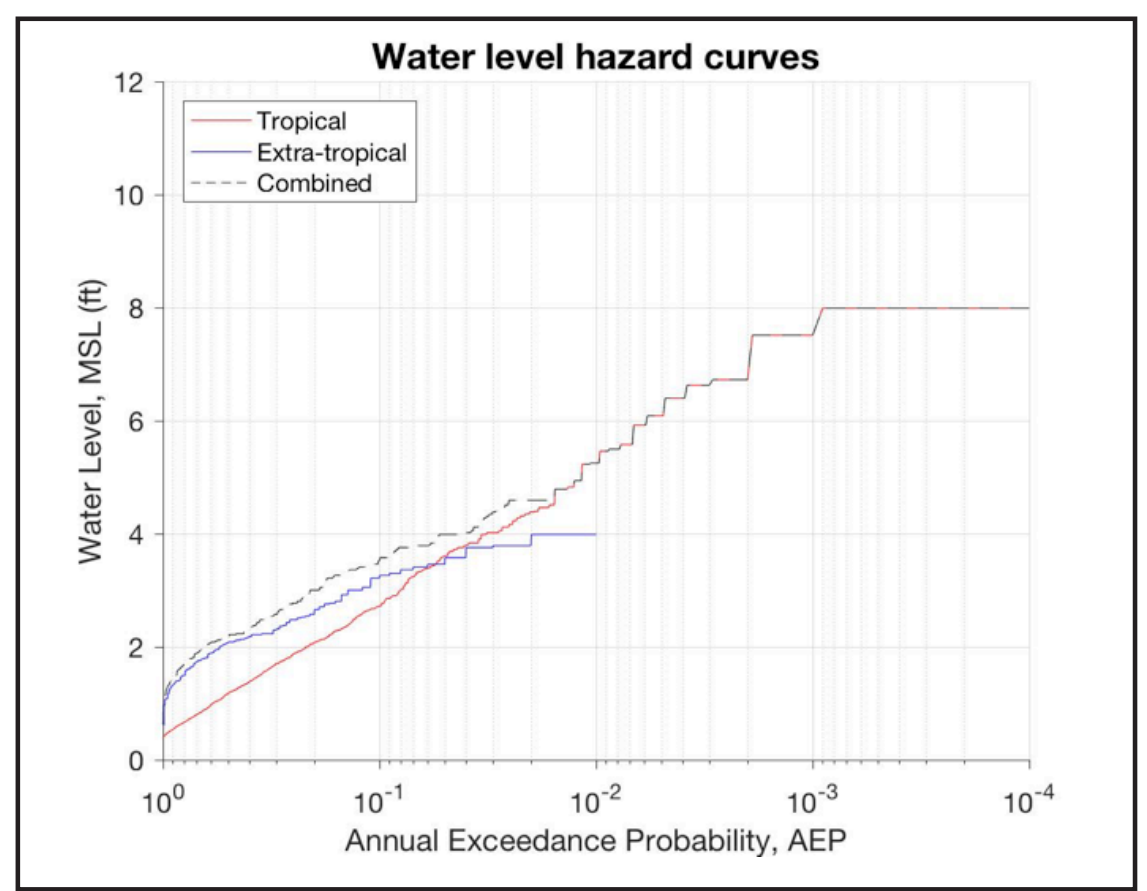

Figure 5.1. Water level hazard curves as a function of annual exceedance probability (AEP) for simulated tropical, extra-tropical, and combined storm distributions of surge maximum from the NACCS model save point near the mouth of the Piscataqua River in 33-foot water depth. An AEP of 0.1, 0.01, and 0.001 corresponds to the 10-, 100-, and 1000-year events, respectively. Source: Lippmann et al. (2019). 
the maximum surge with a particular high tide (i.e., the maximum spring tide, mean high water [MHW], etc.). The simulations can then be used to predict the inundation expected from a particular return period storm, overtopping of dunes, maximum current speeds, and flood depth durations.

\section{Linking NACCS to High Resolution Nearshore Models in New Hampshire (Great Bay and Hampton-Seabrook)}

The effects of sea-level rise on future storm surge can be simulated by running the high-resolution models under various sea-level rise scenarios for any given year into the future. This research has begun in New Hampshire (Lippmann, et al., 2019) using the FVCOM model (Chen, et al., 2003). The effects of sea-level rise on storm surge energy transformation and flood and ebb tidal current magnitudes were examined in the two major New Hampshire estuarine systems: Hampton-Seabrook Estuary (HSE) and the Great Bay Estuary (GBE). To address specific federal grant requirements, simulations were computed for the $1 \%$ annual exceedance probability storm surge (5.3 feet) synchronized at HSE with Mean High Water (MHW) both with and without RSLR of 2.4 feet (mid-century estimate for RSLR) and at GBE with the maximum spring tide with and without RSLR of 6.3 feet (end of century estimate for RSLR).

Results for the two estuaries are quite different (Lippmann et al., 2019). For GBE the tides are dissipated by bottom friction as they progress up the narrow Piscataqua River with energy decay of about $50 \%$ at the bridges where the Piscataqua River enters the Little Bay (see also Cook, et al., 2019). Under storm surge forcing the water levels increase throughout the estuary, but the dissipation remains about the same with again $50 \%$ of the energy decaying up to the Little Bay bridges. With the inclusion of RSLR, the models with and without storm surge show similar behavior, with water levels increasing throughout the estuary but with the same dissipation. This suggests that projections for the inundation in the GBE under storm surge and RSLR can be reasonably approximated based on the expected dissipation occurring in the estuary today. In other words, since the spatial variation in dissipation estimates throughout the estuary (obtained from present day observation) do not change substantially under storm surge and RSLR (Lippmann, et al., 2019), prediction of total water levels everywhere can be easily estimated. For example, a storm surge of 5.3 feet at the mouth of the Piscataqua River occurring at maximum spring tide elevation (about 6.5 feet above Mean Sea Level (MSL)) results in a total increase in water level at the mouth of the estuary of 11.8 feet above MSL; this value reduces to 5.9 feet at the Little Bay bridges and remains about the same throughout the upper regions of the Great Bay. Perhaps of greater value for land-use planning and engineering design, is the effect on storm surge magnitude for specific storm events, which is possible to interpret from the NACCS data.

In contrast, for HSE, the dissipation of the tides under present day sea-level is relatively small, with about $4 \%$ energy decay upstream in the tidal channels. Under storm surge forcing, the energy decay increases in the narrow inlet by about 20\%. Under RSLR with and without storm surge the dissipation increases even more, with decay in energy of about $30-40 \%$ in the inlet and an additional $5 \%$ throughout the back bay areas. This suggests that, although water levels will increase under storm surge and RSLR, the inundation extent at HSE will be somewhat mitigated by the characteristics of the dissipation through the narrow inlet. Figure 5.2 shows an example of the predicted inundation for HSE for the 100-year storm under 2.4 feet RSLR (projected for year 2060) at MHW (Kirshen et al., 2018). 


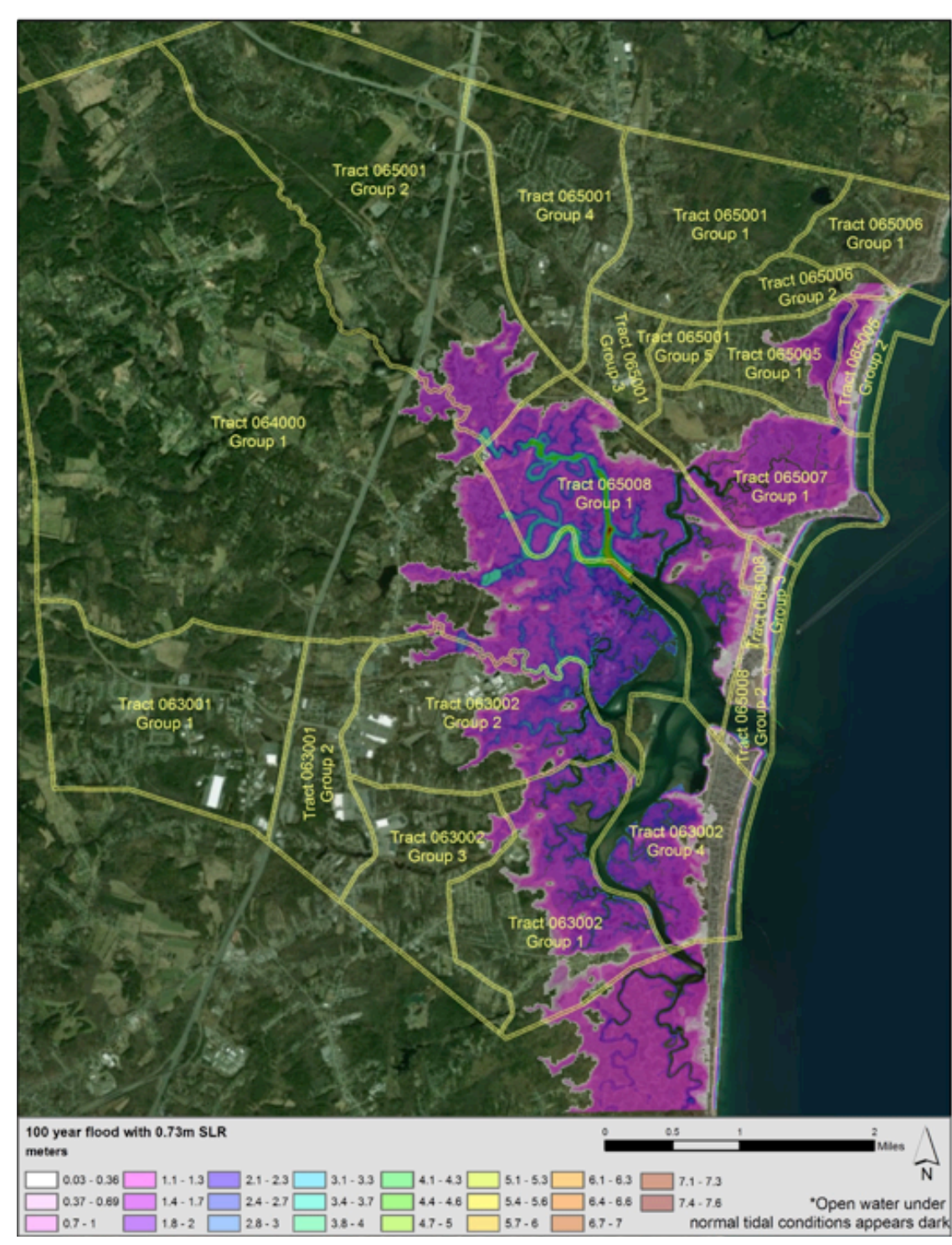

Figure 5.2. Inundation extent for Hampton-Seabrook Estuary under the 100-year (1 \%) storm surge event with relative sea level (RSL) rise of $0.73 \mathrm{~m} / 2.4$ feet occurring at MHW. Source: Kirshen et al. (2018).
Table 5.2 summarizes the inland areas inundated during simulated model runs and the percentage increase from the case of no storm at present day sea level at GBE (synced with spring tide) and HSE (synced with MHW-level tide) for the scenarios with 100-year (1\%) storm and no RSLR, year 2100 SLR (6.3 feet), and the 100-year (1\%) storm with 6.3 feet of SLR (from Lippmann et al., 2019). The impact of inundation from storm surge and RSL on economic and social values requires conducting a social impact assessment (SIA) and social vulnerability index (SVI) for coastal communities. Impacts on ecosystem services depends on the specific wetland areas that are affected and requires localized assessment. Kirshen et al. (2018) examined the effects of climate change on three communities in Hampton, Hampton Falls, and Seabrook, and found that the most socially vulnerable census blocks were 8.6 times more likely to be located in the flood zone than those living in blocks with low social vulnerability (see Figure 10 in Kirshen et al., 2018 for the inundation extent under the 1\% or 100-year storm and 2060 RSL). Under climate change, census blocks with high percentages of the population living in poverty were 17.7 times more likely to be located in the flood zone, and that the analysis reflects the winter/spring population more than the summer population in coastal areas. These populations are also more at risk from storm surge alone (without consideration of wave effects on the oceanfront beaches and dunes). Estimated costs associated with damage to structures can be compared to estimated costs to develop and implement coastal adaptation strategies and engineering of coastal protection barriers. Changes to salt marsh characteristics were more heavily weighted toward SLR impacts and result in most of the high-marsh areas being converted to low-marsh by 2060 unless the marsh can build very rapidly (greater than $5 \mathrm{~mm}$ per year). 
Table 5.2. Inland areas inundated $\left(\mathrm{km}^{2}\right)$ during simulated model runs and the percentage increase from the case of no storm, present day sea level. GBE runs are for inundation at spring tide while HSE runs are for inundation at tidal elevations near MHW. The 2100 RSLR projection from NOAA (6.3 feet) was selected for both estuaries for comparison. Source: Lippmann et al. (2019).

\begin{tabular}{|c|c|c|c|c|}
\hline \multirow{2}{*}{ Estuary } & No Storm & $1 \%(100$-year) Storm & No Storm & $1 \%(100$-year) Storm \\
\cline { 2 - 5 } & No RSLR & No RSLR & 6.3 feet RSLR & 6.3 feet RSLR \\
\hline Great Bay & $58.4 \mathrm{~km}^{2}$ & $77.2 \mathrm{~km}^{2}(32 \%)$ & $70.5 \mathrm{~km}^{2}(21 \%)$ & $86.8 \mathrm{~km}^{2}(49 \%)$ \\
\hline Hampton-Seabrook & $10.8 \mathrm{~km}^{2}$ & $24.7 \mathrm{~km}^{2}(129 \%)$ & $24.1 \mathrm{~km}^{2}(123 \%)$ & $28.1 \mathrm{~km}^{2}(160 \%)$ \\
\hline
\end{tabular}

\section{Effects of Storm Surge on Currents}

The simulated model results also show that depth-averaged flood and ebb tidal current magnitudes down the center of the main channel in the GBE could increase by $25 \%$ under projected 6.3 feet RSLR, and by $50-100 \%$ under storm surge forcing with and without RSLR. Similarly, in HSE, depth-averaged flood and ebb tidal currents in the inlet are expected to increase by a factor of two to three under storm surge, and further increase under RSLR. Table 5.3 summarizes the fractional increase in the average and maximum ebb and flood tidal currents relative to the case with no storm and 2019 sea level for GBE (at spring tides) and HSE (at MHW-level tides) for the scenarios with 100-year storm and no RSLR, 6.3 feet RSLR, and the 100-year storm with 6.3 feet RSLR (Lippmann et al., 2019). Simulations suggest that RSLR will have a substantial effect on activities and processes where current strength, increased bottom stress, and structural loading are important, such as safe navigation, mooring design, bridge and pile scour and structural integrity, and sediment transport and bank erosion.

Table 5.3. Fractional increase in the average and maximum currents for the flood and ebb phases for three scenarios. GBE runs are for spring tides while HSE runs are for MHW tidal heights (in feet). Source: Lippmann et al. (2019).

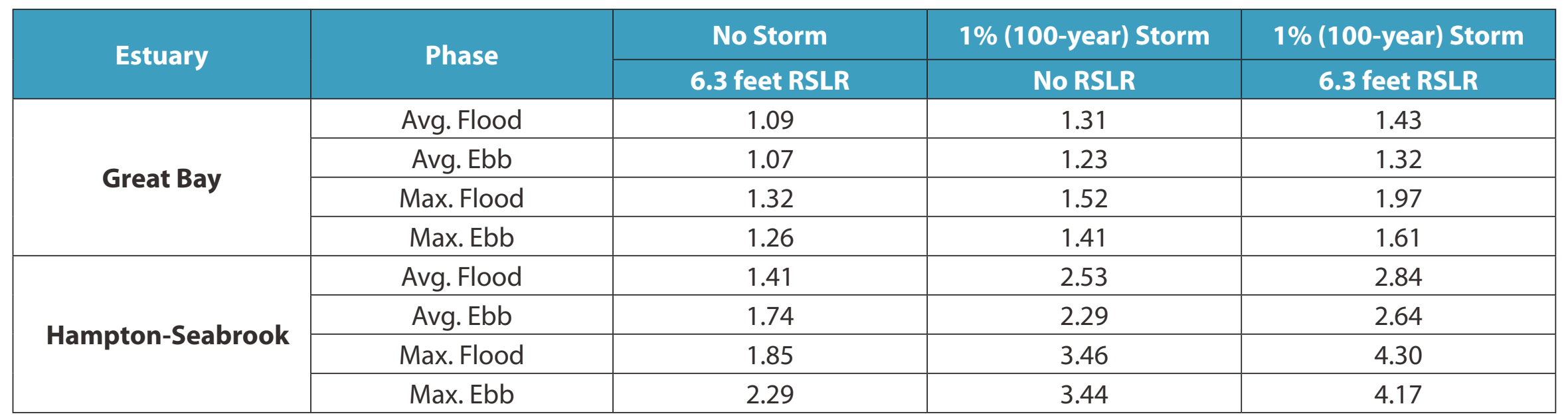




\section{BOX 5.2: MAXIMUM CURRENTS UNDER STORM SURGE WITH SEA-LEVEL RISE}

- High resolution model simulations suggest that maximum flood and ebb currents will increase under storm surge in the presence of sea-level rise.

- Flood and ebb tidal currents will also increase under sea-level rise, even without storm surge.

- Consequences of increased currents include loading forces on structures, increased bottom stress and sediment resuspension, marsh and riverbank erosion, and impacts on mooring design and navigation.

\section{Storm Waves and Sediment Transport}

It should be noted that these model simulations do not include effects from storm waves. This is particularly important along open coast sandy beaches where beach and dune overtopping could occur and where wave forcing (e.g., wave set-up) and swash motions (e.g., wave run-up) could further increase water levels at the shoreline during storms. In addition, the simulations were run on 2019 bathymetry and topography that will likely not be the same in future years where incremental or sudden changes in sediment deposition and erosion patterns may occur in the future. Moreover, the incremental rise in sea level will raise water levels at the shoreline and in estuaries and salt marshes allowing waves and currents to impact larger areas including uplands not presently subjected to erosional forces and flooding.

\section{Climate Change Impacts on Storm Intensity and Frequency} Increases to global ocean temperatures due to climate change could lead to changes in the frequency, intensity and behavior of extreme tropical cyclones (Houser et al., 2014; Kossin et al., 2017). For example, in the North Pacific Ocean, the observed location of the annual mean tropical cyclone peak lifetime intensity has shifted about two degrees poleward over the past 60 years. This change can have a substantial effect on the exposure and risk to coastal communities. The effects in the North Atlantic are not as well established, yet strong correlation between sea surface temperature and increases in hurricane activity in Atlantic storm development regions suggests that future North Atlantic storms could become more intense and more frequent (Emanuel, 2007; Emanuel, 2013; Knutson et al., 2013), particularly in light

\section{BOX 5.3: FUTURE CHANGES IN TOPOGRAPHY AND STORM INTENSITY}

- Changes to coastal topography due to sediment transport (e.g., erosion and deposition along beach and dunes, salt marshes, and river banks) and human interventions (e.g., sediment nourishment or implementation of engineered structures) over many years will change the effects of forecasted storm surge under sea-level rise scenarios.

- Changes to the intensity of extreme storms will likely increase storm surge estimates (Kossin et al., 2017). 
of projected increases in sea surface temperature over the next century. Horton et al. (2015) estimate that the number of intense hurricanes, extreme hurricane winds, and hurricane precipitation are "more likely than not" going to increase by the year 2080, but conclude that the change to future nor'easters is unknown. Nonetheless, ignoring the possible effects of increasing extreme storm intensity and frequency could substantially underestimate the damages and risks associated with future storm impacts (Pielke et al., 2008). If extreme storms increase in intensity, then results from, for example, the NACCS study, would likely under-predict the maximum water level changes under extreme events for any given return period storm. Herein we discussed the potential storm surge from the NACCS study without consideration of climate-induced increases in storm intensity or frequency, and thus it should be recognized that the 100-year return period storm surge estimated from the NACCS might well be the 10 or 50-year (or some other more frequent) event in the future. Considering that damage effects from extreme storms increase substantially as the storm intensity increases, the impacts on risk assessment could be also be substantial, but large uncertainties in extreme storm projections over the next century make it difficult to confidently incorporate potential changes in storm properties into storm distributions for climate change impacts (Houser et al., 2014). This is an important area of ongoing research, and should be more fully considered in future studies of storm surge impact on coastal change and damage in New Hampshire.

\subsection{EMERGING TRENDS IN COASTAL STORMS}

Estimates of inundation and increases in current velocities resulting from extreme storms have impacts on buildings and infrastructure in coastal areas. Estimates of the damage at the individual structure level can be provided from a Coastal Environmental Risk Index (CERl; Spaulding et al., 2016). CERI uses NACCS AEP curves as offshore boundary conditions to compute nearshore wave propagation in the presence of storm surge using STWAVE (Smith et al., 2001). The simulations provide the parameters to apply the NACCS damage curves and calculate the CERI in inundated coastal areas at residential scales. CERI has been used to examine the effects of RSLR and shoreline erosion on damage to coastal homes in Rhode Island (Grilli et al., 2017). Advancements to CERI with more sophisticated nonlinear models that include dynamic wave effects (like wave set-up and run-up) is the subject of ongoing research efforts. Applications of simulated extreme storm inundation and water levels can be used to estimate the damage provided the first finished floor elevation and economic data is available for specific buildings. Efforts to expand CERI to coastal New Hampshire have been proposed and collaborations amongst academic and governmental teams among New England states have begun.

One area of additional research should focus on the interaction among RSLR, storm surge, and heavy precipitation on flooding in the Great Bay Estuary. More detailed discussion of this topic is provided in Section 8.5. 


\section{SEA-LEVEL RISE INDUCED GROUNDWATER RISE}

\subsection{KEY FINDINGS}

GW 1. Coastal groundwater levels will rise with RSLR.

Tidal-water inundation is commonly recognized as an important consequence of RSLR, but RSLR-induced groundwater rise will also impact coastal areas. The Groundwater Rise Zone (GWRZ) is projected to extend up to 2.5 to 3 miles inland from the coast in coastal New Hampshire. This is approximately three to four times farther inland than tidal-water inundation.

GW 2. Mean groundwater levels are projected to rise as a percentage of RSLR with the magnitude of groundwater rise decreasing with distance from the coast.

Mean groundwater levels are projected to rise $66 \%$ of the projected RSLR between $0-0.6$ miles inland of the coast, $34 \%$ between $0.6-1.2$ miles, $18 \%$ between $1.2-1.9$ miles, $7 \%$ between $1.9-2.5$ miles, and $3 \%$ between $2.5-3.1$ miles of the coast. More than five feet of RSLR-induced groundwater rise is projected to occur in approximately one-half of the land area within 0.6 miles of the coast with 6.6 feet of RSLR.

GW 3. The magnitude and extent of RSLR-induced groundwater rise is influenced by the coastal geometry, geology, and the proximity of freshwater discharge areas such as streams and freshwater wetlands.

The magnitude of RSLR-induced groundwater rise decreases with distance inland from the coast, but other factors also influence the spatial variability of RSLR-induced groundwater rise. The projected magnitude and inland extent of groundwater rise is greatest in northern coastal New Hampshire including Newington, Portsmouth, Greenland and Rye, where the groundwater is influenced by tidal water on three sides. Groundwater rise is dampened near streams accompanied by an increase in streamflow possibly producing localized inundation in some riverine floodplains. 


\subsection{CHANGES FROM 2014 STAP REPORT}

RSLR-induced groundwater rise was not evaluated in the 2014 STAP Report.

\subsection{UNDERSTANDING SEA-LEVEL RISE INDUCED GROUNDWATER RISE}

High-tide and storm-related flooding have been recognized as consequences of RSLR and many vulnerability studies and adaptation plans attempt to address this concern. Studies have shown that coastal groundwater will also rise with RSLR resulting in other potential impacts discussed below (Bjerklie et al., 2012; Cooper et al., 2015; Habel et al., 2017; Knott et al., 2018a; Masterson and Garabedian, 2007; Masterson et al., 2014; Oude Essink et al., 2010; Rotzoll and Fletcher, 2013; Walter et al., 2016).

Fresh and saline groundwater and surface water interactions near the coast are complex as shown in Figure 6.1. Groundwater flows from inland areas with high hydraulic head to low hydraulic head at the coast where groundwater discharges to the sea. Groundwater levels depend on aquifer recharge, groundwater discharge to surface-water bodies, groundwater withdrawals, evapotranspiration, and sea level (Anderson and Emanuel, 2010; Charette et al., 2012; Mulligan and Charette, 2006). As sea levels rise, groundwater will also rise until a new equilibrium is established between aquifer rechargeand groundwaterdischarge, withdrawals, and other losses. Due to the interconnectedness of the groundwater and surface-water systems, RSLR-induced groundwater rise may contribute to water-quality degradation, saltwater intrusion, and streamflow increases as represented by numbers 2, 3, and 4, respectively, in Figure 6.1.

RSLR-induced groundwater rise is expected to impact many parts of the coastal United States. In areas where groundwater is shallow, groundwater rise may result in land-surface inundation

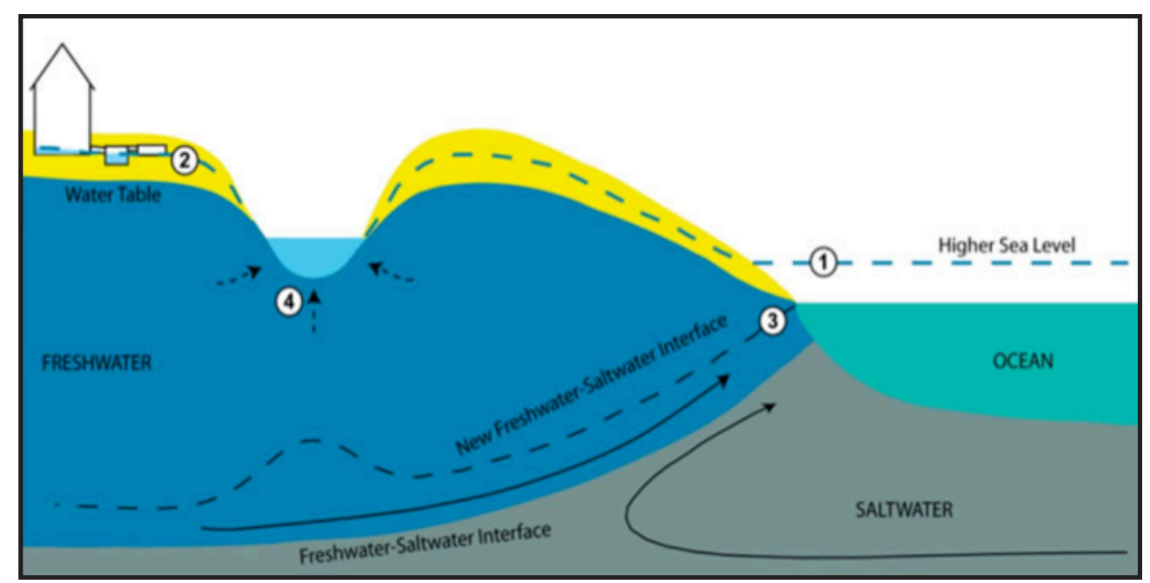

Figure 6.1. Schematic drawing showing the interconnected system of groundwater (fresh and saline) and surface water. Some consequences of rising groundwater are indicated: (1) SLR-induced groundwater rise, (2) septic system failure and basement flooding, (3) landward movement of the freshwater/saltwater interface, and (4) increased groundwater discharge to streams. Source: U.S. Geological Survey; not to scale, vertically greatly exaggerated.

and wetlands expansion, and it may degrade the integrity and function of infrastructure (Bjerklie et al., 2012; Knott et al., 2018a; Masterson et al., 2014). Rising groundwater is projected to cause flooding problems at the Homestead Air Reserve Base in Florida (Cooper, H. et al., 2015) and double the area of land inundation in Honolulu, Hawaii (Rotzoll and Fletcher, 2013). RSLR-induced groundwater rise is also predicted to have serious consequences for ecology and water quality in barrier island ecosystems (Manda et al., 2015; Masterson et al., 2014). Freshwater and saltwater wetland ecosystems, including vegetation, biota, and substrate, are sensitive to water depth, flooding frequency and duration, and salinity changes (Lorah and Olsen, 1999; Masterson et al., 2014; Wilson et al., 2012). Consequently, hydrologic changes associated with RSLR and RSLR-induced groundwater rise can result in wetland expansion, migration or transition (Moffett et al., 2012). Infrastructure is also at risk from rising groundwater. 
Coastal-road pavements experience premature failure when rising groundwater moves into the supporting base material (Knott et al., 2017; Roshani, 2014). On-site wastewater treatment systems are at a high risk of failure when the vertical separation between the leaching field and the groundwater table no longer meets the protective standards (Habel et al., 2017; Manda et al., 2015), and centralized wastewater treatment efficiencies can be reduced when groundwater infiltrates the collection systems (Flood and Cahoon, 2011).

Scientifically based numerical models are useful for simulating future conditions over the long-time frames associated with RSLR (Pitz, 2016) and groundwater models have been used to simulate past and future groundwater flow and transport. Many of these studies have used USGS MODFLOW (Harbaugh, 2005) for 3-dimensional numerical modeling of RSLR-induced groundwater changes (Bjerklie et al., 2012; Habel et al., 2017; Masterson and Garabedian, 2007; Masterson et al., 2014; Oude Essink et al., 2010; Walter et al., 2016). In coastal New Hampshire, a regional MODFLOW model was used to investigate the effect of RSLR on groundwater levels (Knott et al., 2018a). Coastal New Hampshire has a rich variety of natural resources including rivers and streams, fresh and saltwater wetlands, and marine environments and the 3-dimensional model was chosen to simulate the region's complex hydrogeology and groundwater/ surface water interactions (Knott et al., 2018a; Mack, 2009).

Changes in coastal ground water levels are caused by many factors in addition to RSLR. Changes in temperature, evapotranspiration, precipitation, runoff, snowmelt, and land development will all contribute to groundwater-level changes. For example, an increase in extreme rainfall events may or may not raise groundwater levels. The increased precipitation may infiltrate the ground as recharge raising groundwater levels or the precipitation may come at such a high rate that it runs off without infiltrating the ground surface. Recent research has shown that climate change may cause a $10 \%$ increase in annual recharge rates in the New Hampshire coastal region over the next century. On the other hand, increases in the amount of impervious surface associated with population increases may decrease recharge by 5 to $10 \%$ with a corresponding increase streamflow (Bjerklie and Sturtevant, 2017b). Also, increasing groundwater withdrawals for drinking water may locally reduce groundwater tables (Mack, 2009), possibly enhancing saltwater intrusion near the coast. This chapter focuses only on groundwater level changes caused by RSLR and recharge rates and ground water withdrawals were held constant to isolate this effect.

\subsection{HISTORICAL TRENDS IN SEA-LEVEL RISE INDUCED GROUNDWATER RISE}

While many of the studies showing coastal RSLR-induced groundwater rise are modeling studies, long-term increases in groundwater level have also been measured in the field. For example, groundwater levels were measured in well TSW 1 located approximately $980 \mathrm{ft}$ from the coast on Cape Cod over a 51-year period from 1950 through 2000 (Figure 6.2). Groundwater rose $2.1 \mathrm{~mm} /$ year in this monitoring well compared to a $2.3 \mathrm{~mm} /$ year rise in sea level recorded at the Boston tide gauge over the same period (McCobb and Weiskel, 2003).

In southern Florida, a reduction in the soil storage capacity associated with high sea levels was identified farther inland than high-tide flooding in wells with at least 30 years of record in Palm Beach, Miami Dade and Broward Counties. The soil storage capacity is proportional to the land surface-to-groundwater separation. As groundwater rises, the soil storage capacity is reduced, resulting in an increased risk of flooding (Bloetscher et al., 2016). 

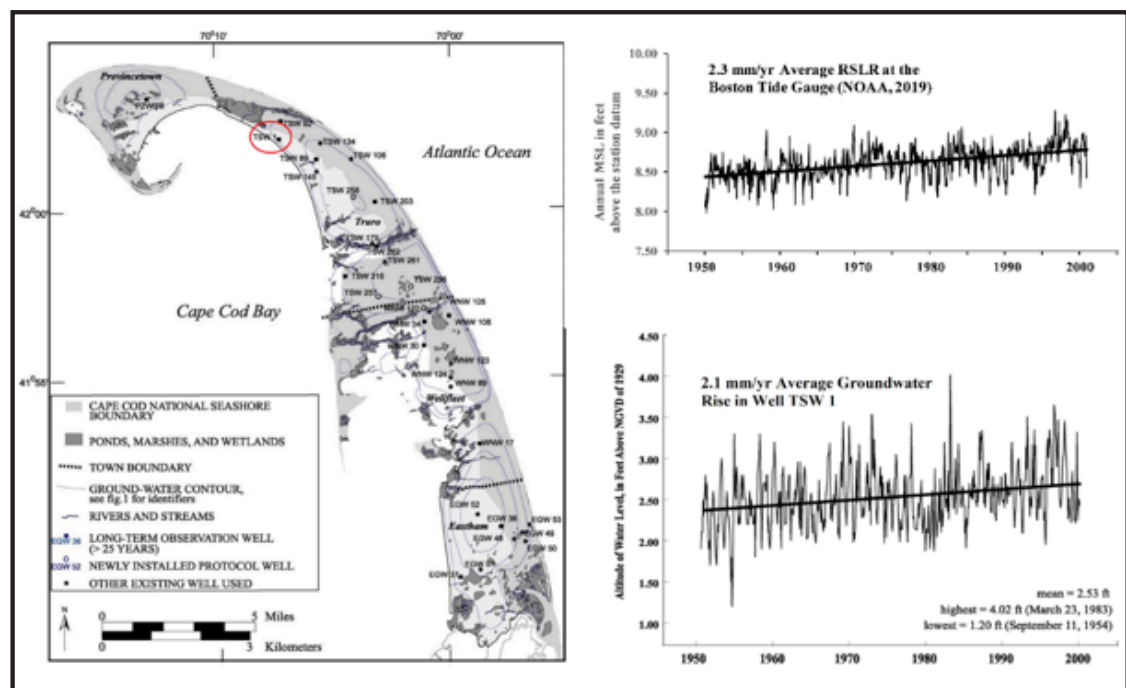

Figure 6.2. Groundwater levels measured in well TSW 1 compared with surface-water levels measured at the Boston tide gauge (NOAA, 2019). TSW 1 is circled in red on the map of outer Cape Cod. Source: McCobb and Weiskel (2003).

\subsection{SEA-LEVEL RISE INDUCED GROUNDWATER RISE PROJECTIONS}

Knott et al. (2018a) investigated RSLR-induced groundwater rise for four future sea levels projected to occur by early-midcentury, late-mid-century, and end-of-century and mapped a Groundwater Rise Zone (GWRZ) in coastal New Hampshire (Knott et al., 2018a). The GWRZ is the area where groundwater is projected to rise with RSLR. The study area is shown in Figure 6.3.

\section{Groundwater Modeling Methodology}

An existing numerical groundwater-flow model (Mack, 2009) was updated and modified to investigate the effect of RSLR on ground water levels in coastal New Hampshire (Knott et al., 2018a). The U.S. Geological Survey's (USGS) 3-dimensional computer code MODFLOW-2005 (Harbaugh, 2005) was used to predict steady-state groundwater piezometric head at a resolution of

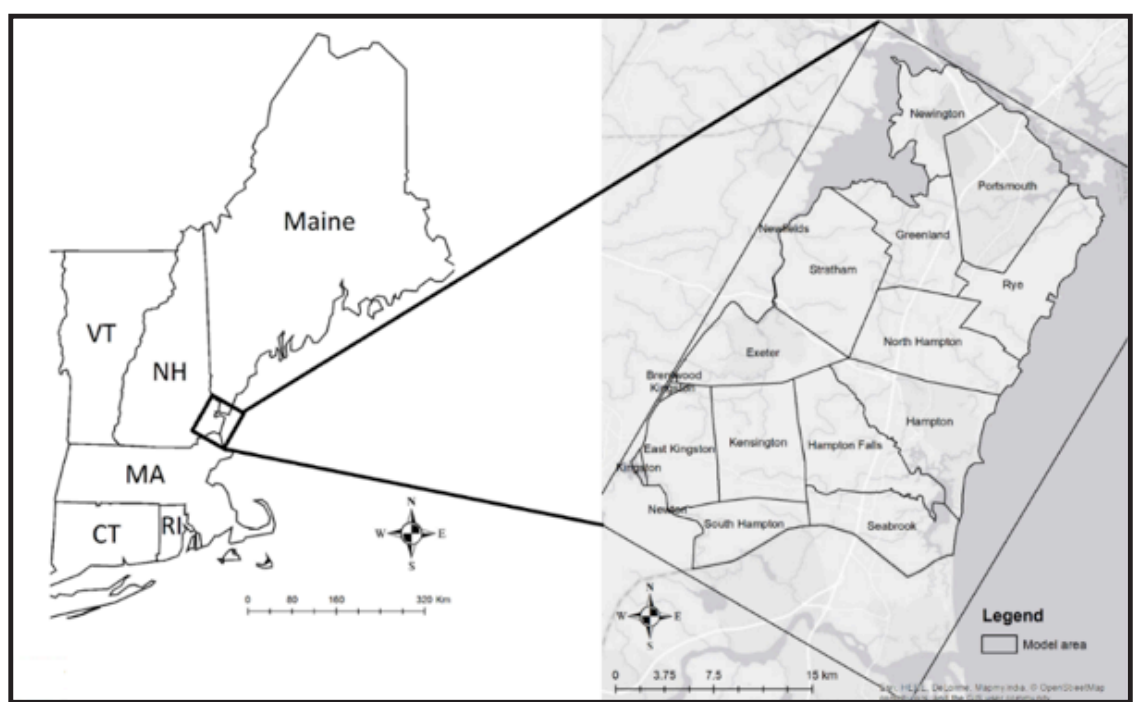

Figure 6.3. The study area in coastal New Hampshire showing the 13 New Hampshire communities included in the groundwater-modeling study. Source: Mack (2009) and Knott et al. (2018a).

200 feet $\times 200$ feet in a model area of $158 \mathrm{mi}^{2}$ in New Hampshire and $30 \mathrm{mi}^{2}$ in Massachusetts. Piezometric head approximates the groundwater-table elevation in unconfined aquifers.

The model consists of five layers, two in the unconsolidated deposits and three in bedrock. The model boundaries correspond to natural hydrologic boundaries including the Gulf of Maine (east), the Piscataqua Estuary (north), the Squamscott River (west), and the Merrimack Estuary in Massachusetts (south) (Figure 6.4). Model inputs included LiDAR land surface elevations (Photo Science Inc., 2011), aquifer recharge (Dripps and Bradbury, 2007), hydraulic conductivity, aquifer thickness, groundwater withdrawals (NHDES Drinking Water \& Groundwater Bureau, personal communication, 2016), rivers/streams (NHDOT, 2010; PREP, 2014; CSRC-UNH, 2006), and stream stage (Photo Science Inc., 2011). The hydraulic conductivity and aquifer thickness were determined from surficial 
and bedrock geology (Lyons et al., 1998; Mack, 2009; Moore, 1990; CSRC-UNH, 2004; Stekl and Flanagan, 1992) and confirmed with boring logs (Barker, 2016; NHDES, 2016). A complete description of the model construction and modifications are given in Mack (2009) and Knott (2018a), respectively.

Groundwater-table elevations were compiled from multiple sources including the NHDES, NH Geological Survey, the U.S. Air Force, USGS and the NH Department of Transportation into a database and contoured. Groundwater heads from 2,919 wells were used in the study, including 1,645 wells installed in unconsolidated deposits and 1,274 in bedrock. Monitoring wells with accurately surveyed elevations were used for model calibration. Groundwater heads in wells that were not surveyed and surface-water elevations were estimated using LiDAR ground-surface elevations referenced to the North American Vertical Datum of 1988 (NAVD88). The topography and groundwater head contours within the study area are shown in Figure 6.4. (Knott et al., 2018a).

Sea level at the coast was initially set at the current MSL (-0.31 feet NAVD88) measured at the Fort Point tide gauge in Portsmouth (NOAA, 2016) for the baseline simulation. The freshwater/ saltwater interface is assumed to follow the coastline due to the low bedrock hydraulic conductivity (Mack, 2004) and saltwater intrusion was not modeled. Density effects were accounted for using freshwater equivalent heads at the coast (Rumbaugh and Rumbaugh, 2011). NOAA's high emissions SLR scenario (relative to 1992) was used to estimate future MSLs (Parris et al., 2012). The use of the Parris et al. (2012) scenarios is consistent with the $\mathrm{NH}$ Coastal Risks and Hazards Commission's (NH CRHC) Science and Technical Advisory Panel (STAP) report (Kirshen et al., 2014). RSLR of 1.0, 2.7, 5.2, and 6.6 feet corresponding to the years 2030, 2060, 2090, and 2100 were simulated. These fall between the likely and unlikely SLR projections for RCP 4.5 (Table 4.2). The MSL boundary

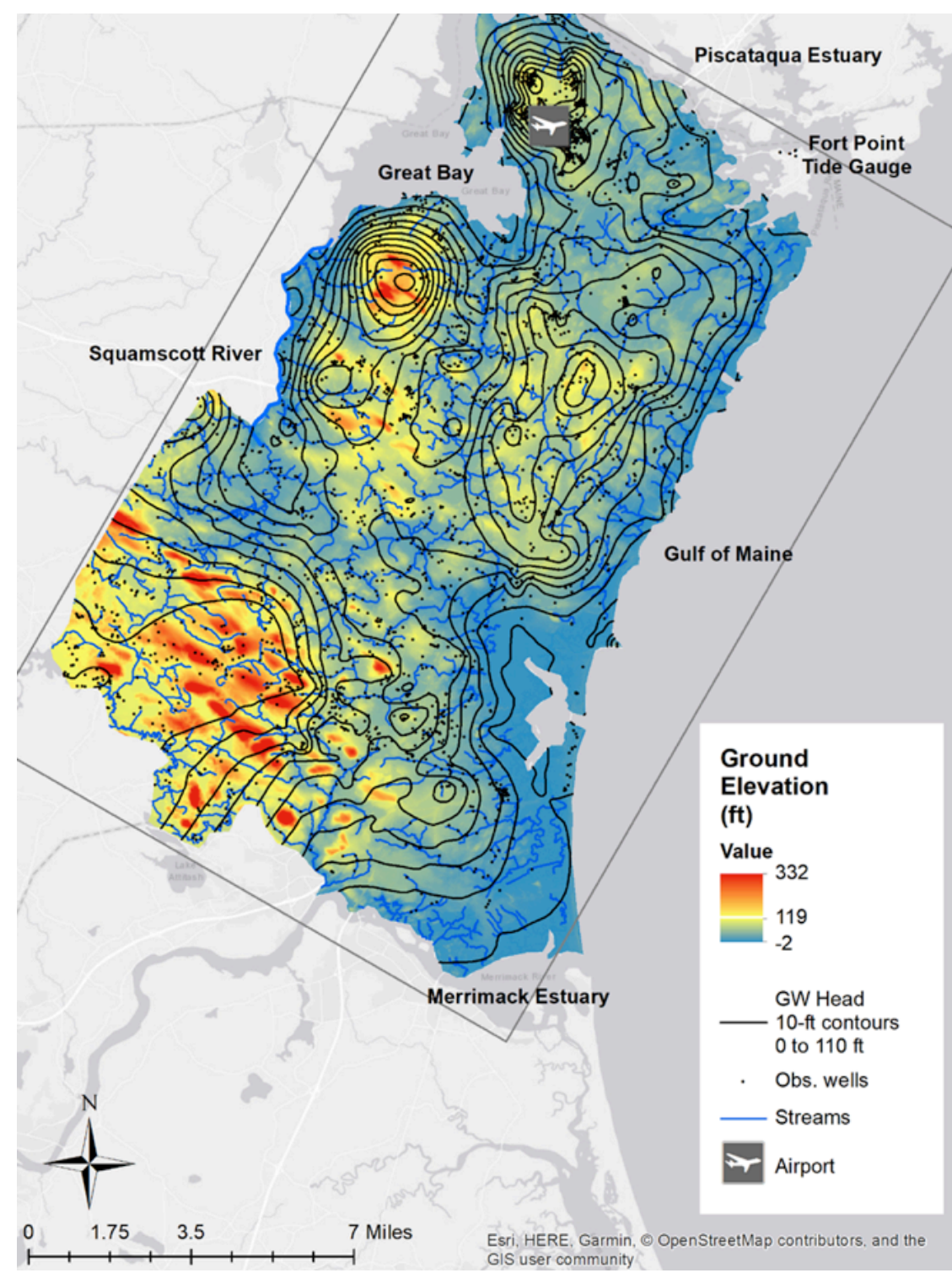

Figure 6.4. Groundwater modeling study area. The rectangular area is the groundwater model domain and the model boundaries, the Merrimack River, Gulf of Maine, Piscataqua Estuary, and Squamscott River, are labeled. Red to blue shading illustrates high to low topography, and observation wells are indicated. Approximate groundwater-table elevations relative to NAVD88 are illustrated with 10-ft contour lines from 0 at the coast to 110 feet at inland locations. Source: Modified from Knott et al. (2018a). 
condition was increased accordingly and the model was run in steady state for each simulation. Groundwater piezometric heads calculated by the model were used to generate digital groundwater elevation models for the current MSL and the four future RSLR states. Groundwater elevations at MSL were then subtracted from the future groundwater elevations to calculate the groundwater rise (Knott et al., 2018a).

\section{Limitations and Assumptions}

RSLR-Induced groundwater rise was simulated in the study area using an existing USGS 3-dimensional groundwater flow model. The model construction, supporting data, inputs, assumptions and limitations are documented in Mack (2009) and Knott et al. (2018a). The assumptions, limitations and uncertainties are briefly discussed here.

The regional model simulates steady-state groundwater flow in the unconsolidated sediments (less than 100 feet thick) and fractured bedrock. The model inputs include topography, annual average aquifer recharge, stream delineation and stage, aquifer material properties and MSL. All these input parameters have uncertainties associated with measurement errors as well as temporal and spatial variability (Knott et al., 2018a). Since the model was run in steady state, seasonal groundwater fluctuations and transient effects such as saltwater intrusion and changes in aquifer storage were not simulated. Despite these uncertainties and assumptions, the model simulations have great value in investigating future trends in groundwater elevations and changing flow patterns caused by projected RSLR. To determine what the future average groundwater levels may be at a location in the study area, projected groundwater rise should be added to the average groundwater levels measured in that local area.
This modeling study is a preliminary investigation of the long-term effect of RSLR on groundwater levels. Other factors that influence groundwater levels such as aquifer recharge and groundwater withdrawals were held constant in the simulations to isolate the influence of RSLR. Recent research on the climate-change impacts on hydrology in New Hampshire have shown that under most GCMs and RCPs groundwater recharge is expected to increase by the mid- $21^{\text {st }}$ century. The projections vary more toward the end of the century depending on the balance between increased precipitation and increase evapotranspiration (Bjerklie et al., 2015; Bjerklie and Sturtevant, 2017a; Bjerklie and Sturtevant, 2017b). It was also assumed that groundwater rise is driven only by piezometric head changes at the coast, i.e. a migrating coastline was not simulated. The coastline will change through inundation, erosion, and sedimentation with RSLR. An increase in recharge and the effect of a migrating coastline have the potential to increase the vertical magnitude and inland extent of groundwater rise suggesting that the estimates presented here may be conservative in some parts of the study area.

Finally, this study considered groundwater rise for 1.0, 2.7, 5.2 and 6.6 feet of RSLR. Additional simulations can be run for different projected sea levels, as well as future changes in recharge and groundwater withdrawals. The model can also be converted to a transient or quasi-steady-state model to investigate seasonal changes and a migrating coastline.

\section{Spatial Distribution of Projected Groundwater Rise}

Groundwater rise is projected to be highest at the coast, decreasing with distance inland. The ratio of mean groundwater rise to RSLR was found to be relatively constant for the sea levels analyzed. Simulated RSLR-induced groundwater rise in the study area is shown as a percentage of RSLR in Figure 6.5. The hatching 


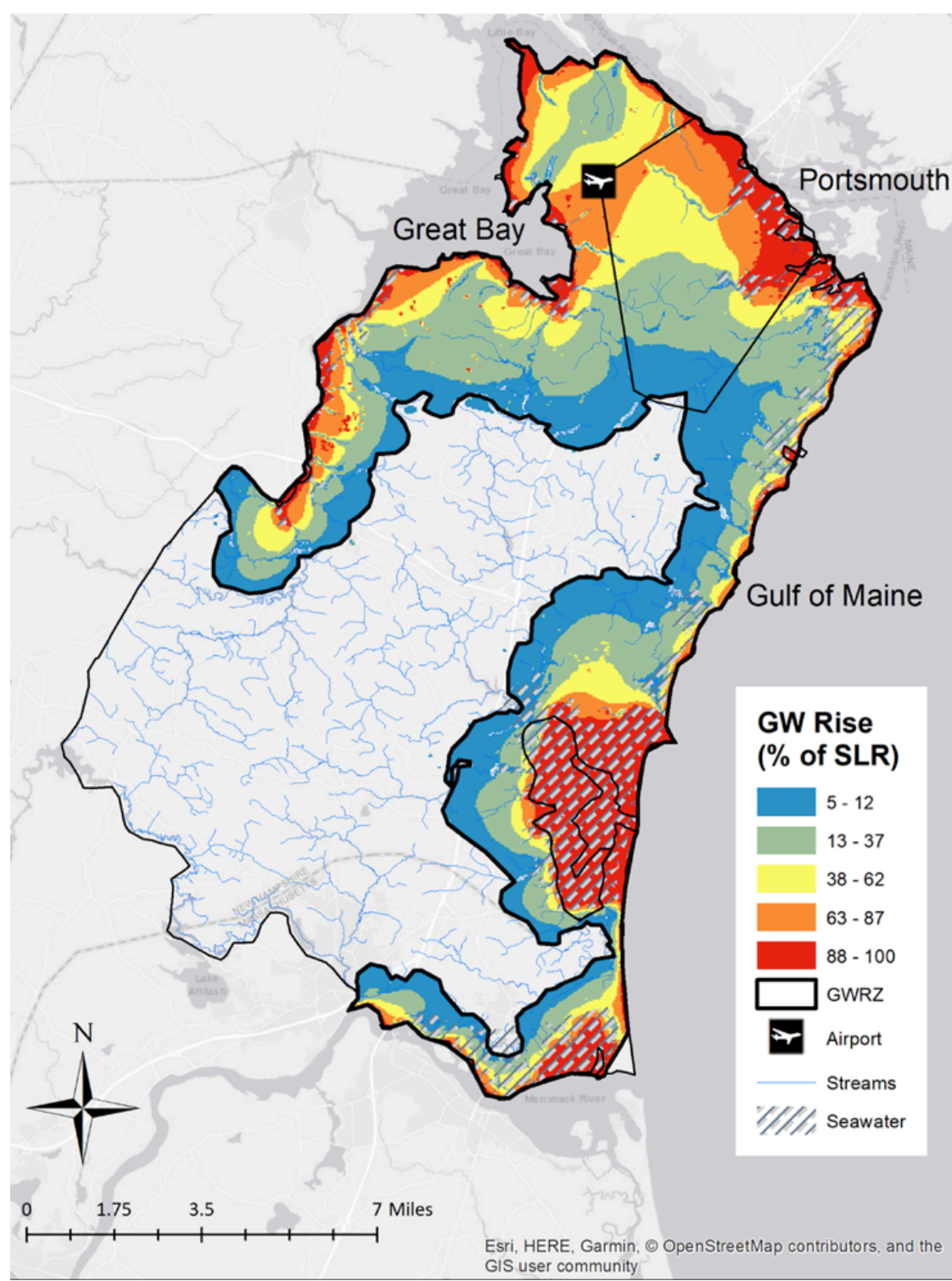

Figure 6.5. Projected groundwater rise as a percent of RSLR in the coastal New Hampshire study area. Source: Modified from Knott et al. (2018a). represents the extent of tidal-water inundation with 6.6 feet of RSLR. The GWRZ, illustrated with colors from light blue to red, extends 3-4 times farther inland than the extent of tidal-water inundation from RSLR. Mean groundwater rise is projected to be $66 \%$ of RSLR between $0-0.6$ miles of the coast, $34 \%$ between 0.6-1.2 miles, $18 \%$ between 1.2-1.9 miles, 7\% between 1.9-2.5 miles, and 3\% between 2.5-3.1 miles of the coast. More than five feet of RSLR-induced groundwater rise is projected to occur in approximately one-half of the land area within 0.6 miles of the shoreline with 6.6 feet of RSLR (Knott et al., 2018a).

The largest magnitude and inland extent of RSLR-induced groundwater rise is projected to occur in the northern part of the study area. Mean groundwater rise that is $50 \%$ of RSLR is projected to occur 1.2-1.9 miles from the shoreline in this subarea (Knott et al., 2018a). For example, with 6.6 feet of RSLR, a mean groundwater rise of approximately 3.3 feet is projected to occur 1.2-1.9 miles from the coast in this area. This is consistent with the findings in New Haven, CT [Bjerklie et al., 2012), but the predicted inland distance of groundwater rise is about one half that found in the sand and gravel aquifer of Cape Cod (Walter et al., 2016).

Box plots of the RSLR-induced groundwater rise calculated in the model grid cells within each distance interval are presented in Figure 6.6. These plots illustrate the inverse relationship between groundwater rise and distance from the coast as well as the large variability around the mean. Because of this large variability, the mean values should be used with caution. While the largest magnitude of RSLR-induced groundwater rise will occur on average near the coast, there are areas near the coast where groundwater rise will be smaller than the average. Likewise, there are areas farther from the coast where groundwater rise 

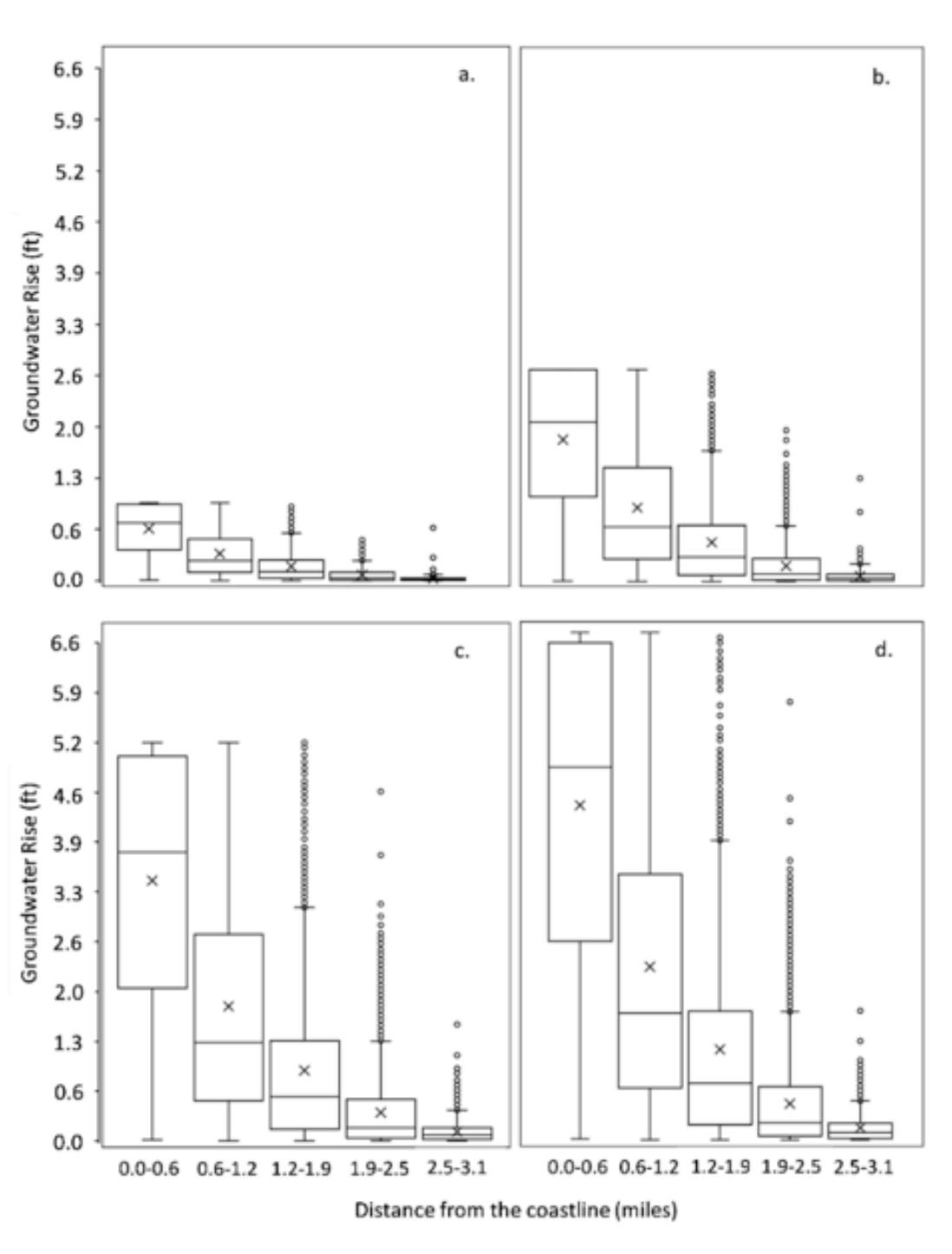

Figure 6.6. Simulated groundwater rise versus distance from the coast for the four sealevel rise scenarios: (a) $1.0 \mathrm{ft}$, (b) $2.7 \mathrm{ft}$, (c) $5.2 \mathrm{ft}$, and (d) $6.6 \mathrm{ft}$. Each box shows the mean $(\mathrm{x})$, median, interquartile range, and outliers for each distance interval from the coast. Source: Knott et al. (2018a). is projected to be greater than the average. This highlights the need to evaluate local hydrogeologic conditions when designing for future groundwater levels (Knott et al., 2018a).

Distance from the coast is not the only factor controlling the spatial distribution of groundwater rise in the study area. The magnitude and areal extent of groundwater rise is influenced by the configuration of the coastal-land area, the geology, and the location of groundwater discharge areas such as streams or wetlands (Bjerklie et al., 2012; Hoover et al., 2017; Knott et al., 2018a; Oude Essink et al., 2010; Walter et al., 2016). Groundwater rise beneath islands or peninsulas is more pronounced than along straight coastlines because these land masses are influenced by sea levels on three or more sides (Knott et al., 2018a; Walter et al., 2016). For example, groundwater rise is projected to be higher in Portsmouth, Newington, and Greenland than in North Hampton due to tidal influence from the Gulf of Maine, the Piscataqua Estuary, and Great Bay. This was also found on Cape Cod where the groundwater rise on the narrow outer Cape is projected to be twice that projected for the wider part of the peninsula (Walter et al., 2016). RSLR-induced groundwater rise is also projected to occur farther inland in highly conductive deposits, such as thick sand and gravel. In the Netherlands, RSLR-induced groundwater rise is predicted approximately six miles from the coast in 690 to 980 feet thick unconsolidated deposits (Oude Essink et al., 2010). RSLR-induced groundwater rise is projected to occur about twice as far inland in the relatively permeable and thick (greater than 200 feet) sand and gravel aquifer on Cape Cod as compared to coastal New Hampshire where the surficial geology is heterogeneous and thin (approximately 40 feet on average) (Mack, 2009). Consistent with these findings, the highest magnitude and extent of 
projected groundwater rise is in the northern part of the study area where the most transmissive geologic materials are found and tidal-water bodies on three sides influence groundwater levels (Knott et al., 2018a).

\section{Increase in streamflow}

The magnitude of RSLR-induced groundwater rise is dampened near streams and accompanied by an increase in groundwater discharge to streams and freshwater wetlands (Bjerklie et al., 2012; Fiore et al., 2018; Knott et al., 2018a; Masterson and Garabedian, 2007; Walter et al., 2016). In the study area, a rise in relative sea level of 6.6 feet is predicted to cause more groundwater discharge to streams and less discharge directly to the ocean. The volume of streamflow is predicted to increase by $13 \%$ and the volume of direct groundwater discharge to the ocean is predicted to decrease by $22 \%$. The dampening of groundwater rise near streams can be seen in Figure 6.4. (Knott et al., 2018a)

This is consistent with the findings in coastal New Jersey, where RSLR-induced groundwater rise resulted in increased groundwater discharge to freshwater streams and wetlands with a corresponding decrease in fresh groundwater discharge to marine water environments (Fiore et al., 2018). On Cape Cod and in New Haven, CT, two very different geological settings, the inverse relationship between groundwater rise and groundwater discharge to surface-water bodies was also discovered. In New Haven, a $34 \%$ increase in streamflow with three feet of RSLR is projected and accompanied by dampened groundwater rise compared to areas without surface-water drainage (Bjerklie et al., 2012). With approximately six feet of RSLR on Cape Cod, where ponds and streams are in direct connection with groundwater, the groundwater discharge to freshwater streams and wetlands is projected to increase from 49 to $61 \%$ of the total outflow with a dampening of groundwater rise around these discharge areas (Walter et al., 2016). The increased groundwater discharge to streams is accompanied by a rise in the freshwater/saltwater interface in some locations on Cape Cod (Masterson and Garabedian, 2007; Walter et al., 2016).

Increased streamflow from groundwater rise could help to maintain summertime streamflow and lower summertime stream temperature, alleviating some adverse effects of climate-change induced temperature increases on stream biota. Increases in streamflow discharging to coastal waters could also change salinities and circulation, with unknown effect.

\section{Groundwater inundation, expansion of wetlands}

Wetlands have been widely recognized for flood control, a function that is essential to the resiliency of waterfronts and coastal economies in the face of RSLR, more intense storms, and storm surge (Linhoss et al., 2015; Walters and Babbar-Sebens, 2016). Inland wetlands provide storage for riverine flood control and coastal wetlands provide both storage and energy dissipation from waves and storm surge. Healthy wetland ecosystems produce food, provide protected areas for spawning and young fish, and attenuate pollutants, all functions important for healthy and thriving fisheries (Graff and Middleton, 2001).

Freshwater and saltwater wetlands are sensitive to the duration of root zone saturation and are, therefore, highly susceptible to changes in groundwater levels (Moffett et al., 2012; Rheinhardt and Fraser, 2001). Long-term changes in groundwater levels, groundwater discharge, and salinity may result in the transition, degradation, or drowning of wetland vegetation (Cooper. et al., 2015; Fiore et al., 2018). In a barrier island ecosystem off the Virginia coast, Masterson et al. (2014) discovered that the freshwater lens between the fresh groundwater table and the freshwater/ 

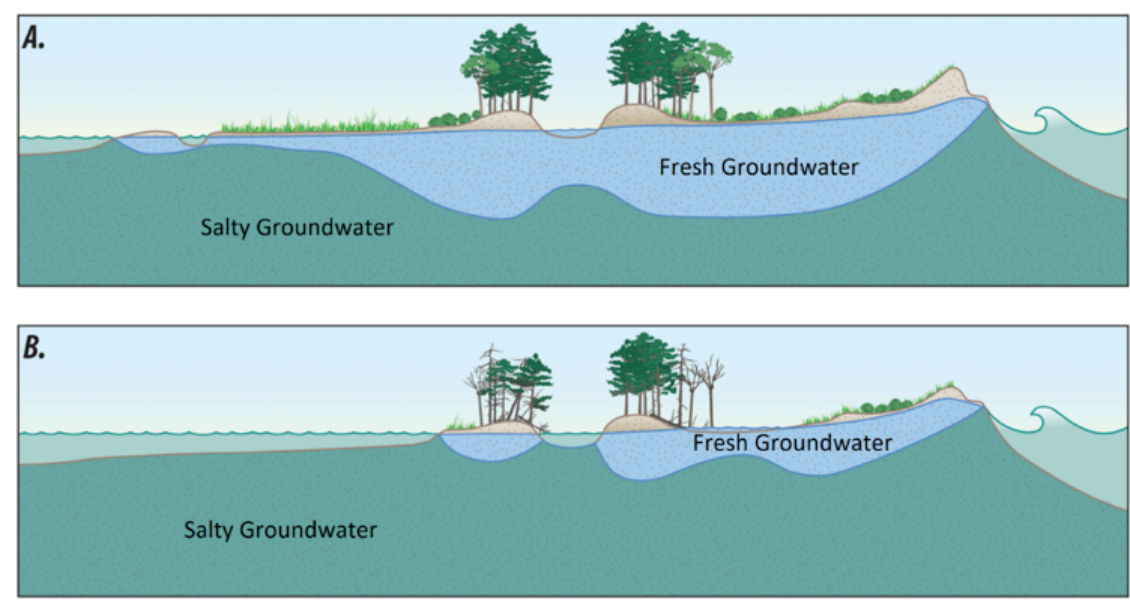

Figure 6.7. Schematic showing RSLR-induced changes to fresh and salty groundwater with implications for the ecosystem at a barrier island in Virginia. Source: Modified from Masterson et al. (2014).

saltwater interface shrinks with RSLR-induced groundwater rise (Figure 6.7).

In the coastal New Hampshire study area, approximately one quarter of the land area is freshwater or saltwater wetland. Approximately $15 \%$ of the wetlands are freshwater consisting of forested/shrub wetlands, emergent wetlands, ponds, lakes, and riverine wetlands, and $10 \%$ are saltwater wetlands (USFWS, 2001). Freshwater and coastal wetlands are both projected to be impacted by RSLR either from tidal-water inundation, groundwater inundation (GWI), or both. Low-lying lands adjacent to existing freshwater wetlands are the most vulnerable to wetland expansion from GWI. Saltwater wetland vegetation and habitat are also expected to migrate, transition, or drown with RSLR (NHFG, 2014; Torio and Chmura, 2013). Wetland expansion has implications for wetlands-protection policy, surface and groundwater quality, and infrastructure. Wetland vegetation transition has implications for flood control, fisheries and habitat.

\subsection{SEA-LEVEL RISE INDUCED GROUNDWATER RISE EMERGING ISSUES}

RSLR-induced groundwater rise in coastal New Hampshire is directly influenced by the magnitude of RSLR projected for the coastal region. Changes in the RSLR projections will also change the groundwater rise projections. RSLR is not the only factor controlling groundwater levels, however. Long-term changes in aquifer recharge (controlled by precipitation, evapotranspiration, runoff, etc.), groundwater withdrawals, and land-use will also influence future groundwater levels (Walter et al., 2016; Knott et al., 2018a; Bjerklie et al., 2012; Bjerklie and Sturtevant, 2017b).

Groundwater rise caused by RSLR will impact both built and natural systems in areas within the GWRZ where the current groundwater is shallow (Knott et al., 2018a; Walter et al., 2016; Masterson et al., 2014). Adaptation planning will require not only knowledge of the magnitude and areal extent of projected groundwater rise, but also the current and projected ground water depth below the land surface.

Rising groundwater is a concern in coastal New Hampshire for the following reasons:

- RSLR-induced groundwater rise will contribute to pavementlife reductions in coastal road infrastructure. The presence of water in the underlying, unbound layers of the pavement structure weakens the structure leading to premature pavement failure. Approximately $77 \%$ of 635 miles of roads in the study area are located within the GWRZ and 23\% have ground water within five feet of the pavements'surface, making them potentially vulnerable to reduced pavement life with RSLR-induced groundwater rise (Knott et al., 2018b). Rising groundwater also has the potential to impact underground utilities in the vulnerable roads' right-of-way (NYCDEC, 2019; Flood and Cahoon, 2011; MassDEP, 2017). 
- Some buildings are at risk from RSLR-induced groundwater rise (NYCDEC, 2019). Many of the buildings in Portsmouth's historic district have basements that are vulnerable to groundwater seepage and uncontrolled moisture is a major cause of deterioration in historic structures. Some, including the Strawbery Banke Museum (2017), have already experienced moisture damage from high groundwater leading to recommendations for groundwater monitoring in this area (Merrill and Gray, 2018). In urban areas, rising groundwater is an engineering concern where buildings or foundations not anchored to bedrock may be destabilized (Johnson, 1994; NYCDEC, 2019).

- Rising water tables can cause inundation of cesspools and septic-system leach fields. This raises concerns that more septic systems will fail and contaminants will be mobilized as rising groundwater moves into or close to septic-system leaching fields (Cooper et al., 2016; Iverson et al., 2015; Mihaly, 2018). Nutrients and bacterial contamination from overland non-point source pollution and septic-system effluent in groundwater discharge are already causing eutrophication and degradation of many coastal surface-water bodies in New Hampshire, including Great Bay (Amador et al., 2018; Anderson, 2016; Ballestero et al., 2004; Berg et al., 2016; Iverson et al., 2015). RSLR-induced groundwater rise will exacerbate these problems in areas where the groundwater separation is already marginal.

- RSLR has the potential to contribute to the inland and upward movement of the freshwater/saltwater interface with implications for water quality in drinking water wells close to the shoreline (Jacobs et al., 2017; Masterson, 2004; Walter et al., 2016). In areas where increased groundwater discharge to streams occurs with groundwater rise, the freshwater/saltwater interface will consequently rise because the direct groundwater flow to the coast is reduced (Masterson and Garabedian, 2007; Walter et al., 2016). Movement of the freshwater/saltwater interface can also be caused by increases in drinking-water demand and pumping volumes (Loaiciga and Pingel, 2007; Masterson and Garabedian, 2007; Walter et al., 2016).

\section{Future Research Needs}

A regional study of RSLR-induced groundwater rise in coastal New Hampshire has identified the GWRZ and the spatial distribution of groundwater rise in the study area (Knott et al., 2018a). This study's research objective was to investigate only long-term RSLRinduced groundwater rise and all other input parameters such as aquifer recharge, groundwater withdrawals, and land use were held constant. Recharge is projected to increase by mid-century based on projected increases in precipitation (Bjerklie et al., 2015; Bjerklie and Sturtevant, 2017a; Bjerklie and Sturtevant, 2017b; Hayhoe et al., 2015). Additional research is needed to assess the combined effect of long-term changes in recharge and RSLR on groundwater levels, and groundwater discharge to streams and coastal discharge areas. In addition, the regional model was run in steady state. Saltwater intrusion, seasonal effects, and a migrating coastline were not simulated. Additional research is needed to investigate potential inland migration of the freshwater/saltwater interface with consequences for drinking water supplies, changes in seasonal groundwater levels that are important for ecosystems and the performance of infrastructure, and the effect of a migrating coastline on the inland extent of the GWRZ.

The expansion of inland and coastal wetlands has implications for land-use planning and development, flood control, and ecosystem management. A preliminary analysis of RSLR-induced groundwater rise on Portsmouth wetlands (Knott et al., 2018a) should be expanded to identify other wetland areas in coastal 
New Hampshire for detailed study. Wetland hydrology is complex with interactions between fresh and saline groundwater and surface water, coupled with sedimentation, erosion, and wetland plant transitions. Changes in groundwater discharge to wetlands and surface-water infiltration may alter salinity and ecosystem function. A more detailed wetlands analysis like the Masterson et al. (2014) barrier island study could be designed to investigate the complex interactions between fresh and saline groundwater and tidal surface waters in the Hampton-Seabrook or Rye wetland ecosystems.

Long-term groundwater rise in areas where groundwater is currently shallow has implications for coastal infrastructure and water quality. Research in coastal New Hampshire has shown that RSLR-induced groundwater rise may result in premature pavement failure in $23 \%$ of the region's roads if adaptation planning is not implemented (Knott et al., 2018b). Similar research should be done to map the groundwater depth for current and rising water tables to identify areas where rising groundwater may mobilize and transport contaminants to sensitive surface-water bodies like Great Bay. This research can provide adaptation-planning guidance and inform policy making in land-use, septic-system design and permitting, and the clean-up of waste disposal sites (Elmir, 2018; Walter et al., 2016). 


\section{PRECIPITATION}

\subsection{KEY FINDINGS}

PPT 1. The magnitude of daily extreme precipitation events has increased by $15-38 \%$ in New Hampshire's coastal watershed since the 1950s. Some of these large precipitation events have contributed to significant springtime flooding events in coastal New Hampshire watersheds.

PPT 2. The frequency of extreme precipitation events is projected to increase over the course of the next several decades, especially in the springtime. This increase will likely result in an increased risk of flooding.

PPT 3. The magnitude of future flooding will depend in part on how much the effective impervious surface changes in the coastal watershed due to development both inland and along the coast.

\subsection{CHANGES FROM 2014 STAP REPORT}

- Key findings similar - more detailed analysis supports basic findings in 2014 report.

- Results from analysis of 29 new statistically downscaled GCM simulations (based on 2017 National Climate Assessment - Climate Science Special Report) are included.

\subsection{PRECIPITATION IN NEW HAMPSHIRE}

New Hampshire is characterized by a humid climate and a relatively uniform distribution of precipitation throughout the year totaling between 40-45 inches on average annually (Runkle et al., 2017). New Hampshire's proximity to the coast and position below the confluence of several major North American storm tracks results in the frequent passage of midlatitude storm systems capable of producing heavy precipitation over one or more days. Coastal New Hampshire is regularly impacted by coastal storms, which in addition to storm surge, often produce heavy precipitation in the form of rain or snow depending on the time of year (Kunkel et al., 2012). 


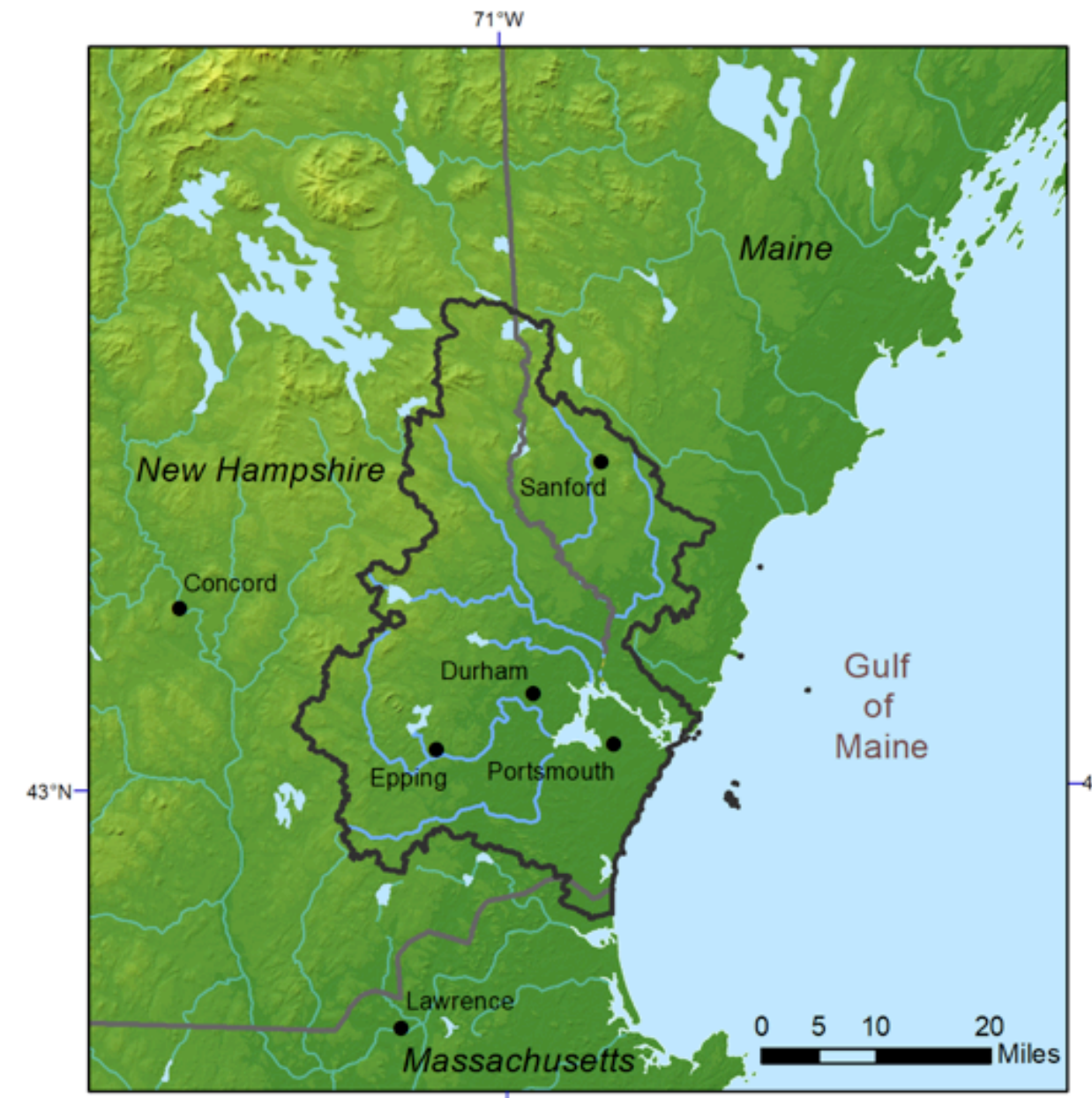

Figure 7.1. Map of New Hampshire's coastal watershed with location of sites where meteorological data was collected.

Total annual precipitation for the U.S. Northeast increased over the 20th century (Hoerling et al., 2016; Huang et al., 2017) and is projected to continue to increase through the end of this century (Hayhoe et al. 2007, 2008; Easterling et al., 2017). This is largely due to increases in precipitation extremes, which are projected to be highest across coastal areas including coastal New Hampshire (Thibeault and Seth, 2014). Commonly used measures of extreme precipitation, like the frequency of heavy daily events exceeding one inch and the intensity of multi-day precipitation events, have increased since the mid-20th century (Wake et al. 2014; Guilbert et al., 2015). Such events are projected to increase over the coming decades and will be a contributing factor in the increase in total annual and seasonal precipitation (Thibeault and Seth, 2014). In addition to RSLR, increases in both total and extreme precipitation will likely increase the flood risk for communities within New Hampshire's coastal watershed (Figure 7.1; Wake et al., 2011, 2014).

\subsection{HISTORICAL TRENDS IN PRECIPITATION (1895 TO 2018)}

Recent increases in precipitation during the summer and fall seasons contributed to an increase in total annual precipitation across coastal New Hampshire of $10-15 \%$ above the early $20^{\text {th }}$ century average (Easterling et al. 2017). These changes are attributed to increases in the intensity of daily events and frequency of extreme multi-day events, particularly during spring and fall (Kunkel et al., 2013; Easterling et al., 2017).

\section{Annual \& Seasonal Precipitation}

Records from United States Historical Climatology Network (USHCN) meteorological stations in Durham, New Hampshire and Lawrence, Massachusetts (Figure 7.1) show increases in total annual precipitation of $14 \%$ and $8 \%$ respectively, above early 20th century average (Table 7.1a). Consistent with Kunkel et al. (2013), the largest seasonal change occurred in fall with increases greater than $20 \%$ at both long-term stations.

Precipitation increased significantly across the region since 1970, driven primarily by significant increases in summer rainfall (Table 7.1b). Historical precipitation data was analyzed from three locations within the New Hampshire coastal watershed (Durham and Epping, New Hampshire, and Sanford, Maine) as well as 
Concord, New Hampshire (just west of the New Hampshire coastal watershed) (Figure 7.1) to explore regional variability. Studies indicate that while the frequency of summer season storms has decreased (Chang et al., 2016), warming increases the intensity of precipitation associated with frontal precipitation and cold season nor'easter type storms (Kunkel et al., 2012; Colle et al., 2013; Janssen et al., 2016). The period evaluated included record breaking summer total precipitation from 2005-2009 and all years from 2004-2015 were above normal (Runkle et al. 2017). There was a slight positive trend in the liquid-water equivalent (total of rain plus melted snow) winter precipitation in Concord and Durham, and a slight negative trend in Epping and Sanford, none of which are statistically significant. A trend toward more precipitation in winter since 1970 was observed in long-term records at other U.S. Northeast stations, but high year to year variability limits interpretation (Huang et al. 2017).

\section{Extreme Precipitation}

Late 20th infrastructure and storm water systems designed for the precipitation return period values published in the "Rainfall Frequency Atlas of the United States: Technical Paper No. 40" (Hershfield, 1961; abbreviated TP-40) are vulnerable to increases

Table 7.1. (a) Long-term (1901-2018) and (b) recent (1970-2018) trends in total annual and seasonal precipitation for weather stations within and close to New Hampshire's coastal watershed. Significant linear trends $(p<0.05)$ are underlined and in bold text. Percent change at USHCN stations in Durham, NH and Lawrence, MA (1901-2018) calculated as present day average for 1989-2018 minus 1901-1960 average divided by 1901-1960 average (following Easterling et al., 2017).

\begin{tabular}{|c|c|c|c|c|}
\hline (a) Long-term change & \multicolumn{2}{|c|}{ Durham, NH } & \multicolumn{2}{|c|}{ Lawrence, MA } \\
\hline Annual & 0.78 & 14 & 0.48 & 8 \\
\hline Spring (MAM) & 0.21 & 13 & 0.09 & 5 \\
\hline Summer (JJA) & 0.20 & 19 & 0.08 & 6 \\
\hline (b) Recent trends & Concord, NH & Durham, NH & Epping, NH & Sanford, ME \\
\hline \multicolumn{5}{|l|}{ Total Precipitation (inches per decade) } \\
\hline Annual & 2.10 & 0.98 & 0.93 & 1.23 \\
\hline Winter (DJF) & 0.24 & 0.25 & -0.22 & -0.24 \\
\hline Spring (MAM) & 0.26 & -0.05 & 0.24 & -0.10 \\
\hline Summer (JJA) & 0.84 & 0.91 & 0.49 & 0.92 \\
\hline Fall (SON) & 0.68 & 0.19 & 0.25 & 0.46 \\
\hline
\end{tabular}


in precipitation extremes (Dupigny-Giroux et al., 2018). The estimates from 1961 are more than one inch lower compared to the revised NOAA Atlas 14 (2015) precipitation frequency estimates for coastal cities (Table 7.2). For both the Durham and Epping stations, the Atlas-14 estimate for the 25-year 24-hour precipitation event increased 1.3 inches ( $26 \%$ increase) since the 1950s, while the 50-year and 100-year 24-hour precipitation event has increased $1.8-2.1$ inches, an increase of $32-36 \%$. Increases farther inland in Concord, New Hampshire for the 25-, 50-, and 100-yr 24-hr storm have been more modest, ranging from 8 to $13 \%$. Point frequency estimates for the Northeast Regional Climate Center's (NRCC) Precip.net database (DeGaetano, 2009) are slightly lower than Atlas-14 for the 25- and 50-year return periods, but slightly higher for the 100-year return period. Consistent with Northeast regional patterns (Easterling et al. 2017), the total amount of precipitation falling during the largest

Table 7.2. The 24-hr point precipitation estimates for 25-, 50-, and 100-year return periods at Concord, Durham, and Epping, NH from NOAA TP-40 (1961), the updated NOAA Atlas-14 (2015), and the Northeast Regional Climate Center (NRCC) Partial Duration Series Extreme Precipitation Estimates (DeGaetano, 2009). Mean precipitation frequency value is shown for all. The upper and lower limits and percent difference from TP-40 is shown for Atlas 14 and precip.net.

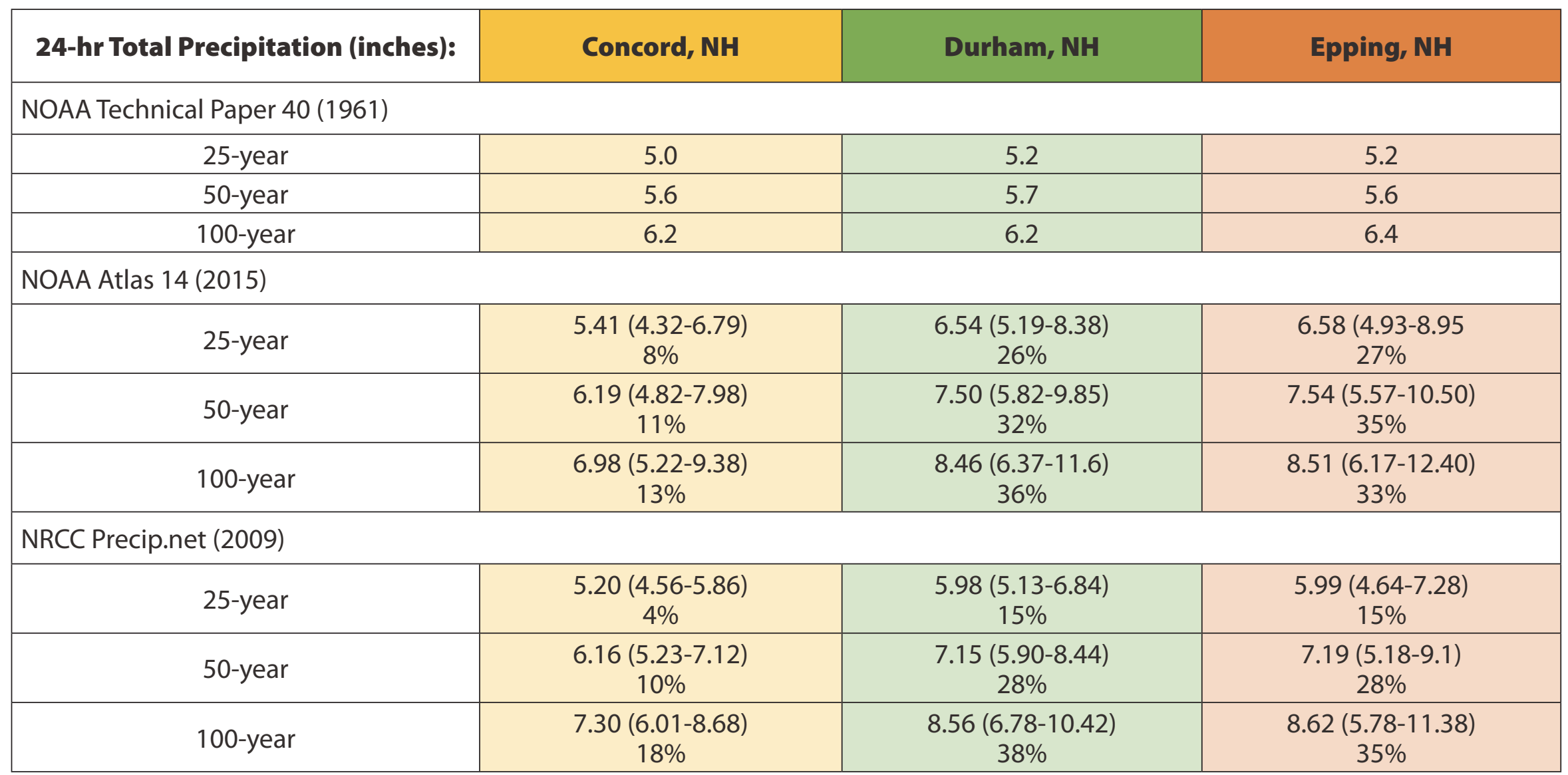


precipitation events has increased since mid-century across coastal New Hampshire.

Among the different measures of extreme precipitation, there was a greater increase in the frequency of extreme, multi-day (4 inches in two days) precipitation events compared to daily precipitation extremes (Table 7.3). As part of the larger, U.S. Northeast regional pattern, most extreme 24-hour precipitation totals occur within multi-day precipitation events associated with passing storms (Agel et al., 2015). On average, daily events of one inch or greater occur approximately 5-10 times per year across coastal New Hampshire and there was a small $(<1$ event per decade) increase in occurrence at three of the four precipitation records since 1970 (Table 7.3b). There was a 12-16\% increase in maximum daily precipitation (PMAX; Figure 7.2 ) and a $14-32 \%$ increase in the occurrence of daily precipitation exceeding the 99th percentile value (Figure 7.3) for present day compared to the early 20th century but the long-term trends were not significant (Table 7.3a). These recent increases in extreme daily precipitation values indicate a change in the magnitude of the trend since the early 2000's consistent with records across coastal northern New England (Douglas and Fairbank, 2011). At Durham station, five of the nine events greater than or equal to 5.2 inches in 24 hours (which represents the TP-40 (1961) value for the 25yr return period threshold) occurred after 1970. Of those five

Table 7.3: (a) Long-term (1901-2018) and (b) recent (1970-2018) trends extreme precipitation for weather stations within New Hampshire's coastal watershed. Significant linear trends ( $p<0.05)$ underlined and in bold. Percent change at USHCN stations in Durham, NH and Lawrence, MA (1901 to 2018) calculated as present day average for 1989-2018 minus 1901-1960 average divided by 1901-1960 average (following Easterling et al., 2017).

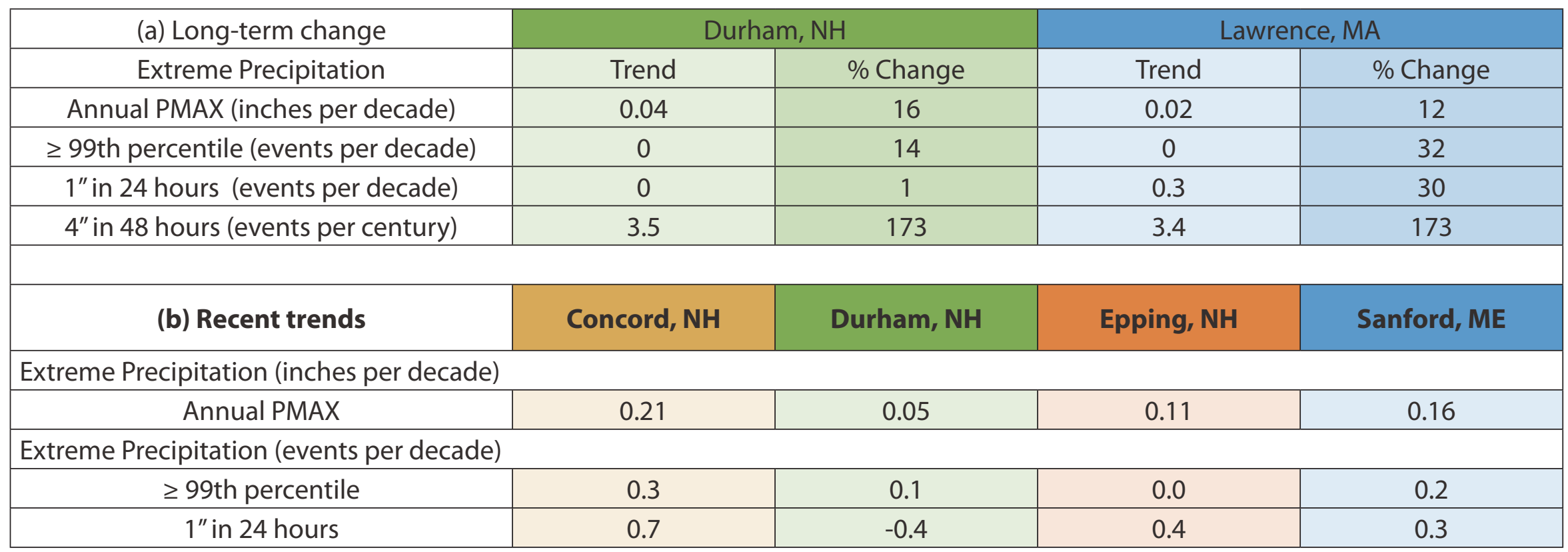




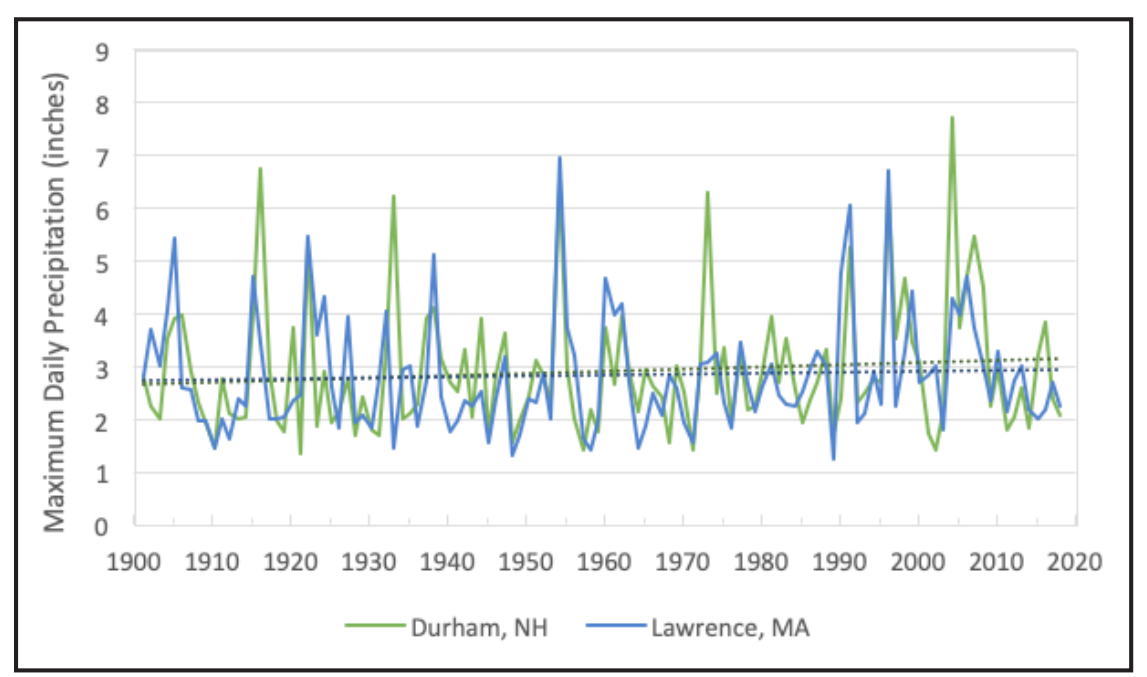

Figure 7.2. Maximum annual daily precipitation at Durham, NH (green line) and Lawrence, MA (blue line) USHCN stations. Linear trends (dotted lines) represent a change in the annual maximum value for daily precipitation of 0.04 and 0.02 inches per decade respectively.

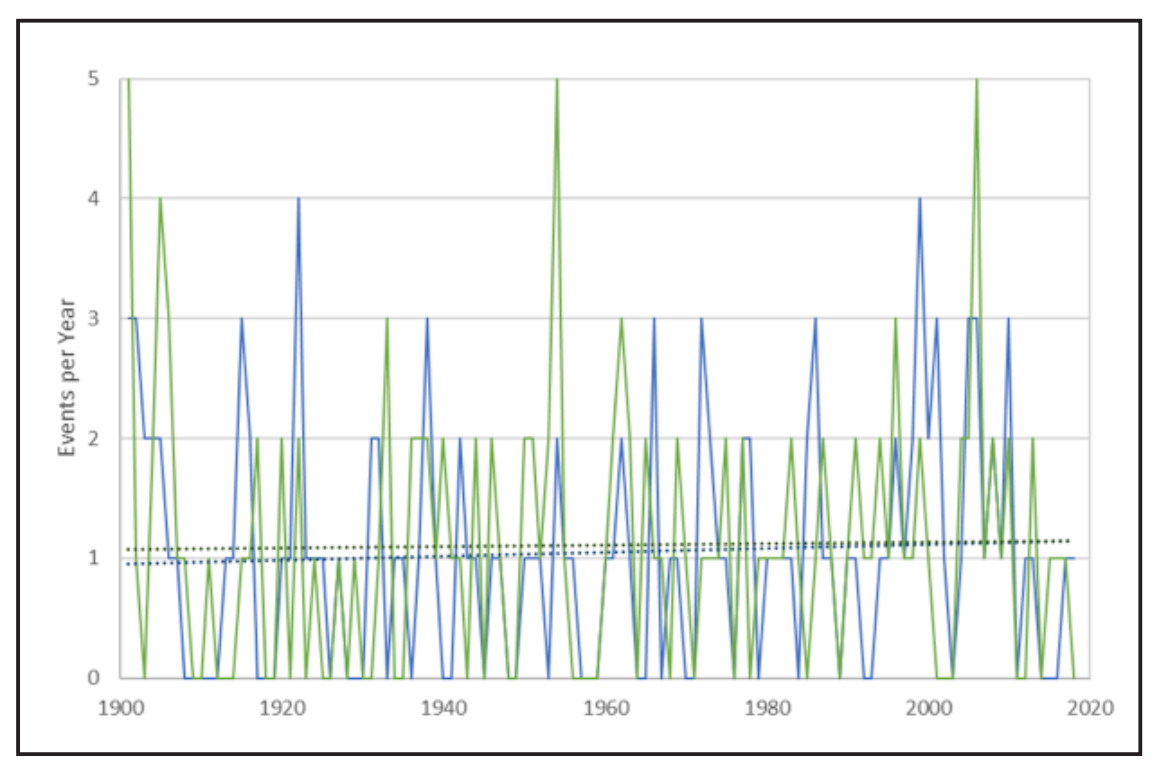

Figure 7.3. Number of events per year exceeding the 99th percentile precipitation value at Durham, NH USHCN Station. Linear trend (dotted lines) are not significant. events, two met the 50-yr return period threshold (5.7 inches) and one surpassed the threshold for the TP-40 100-yr event (6.2 inches). The frequency of extreme multi-day precipitation events ( $\geq 4$ inches over two or more consecutive days) nearly doubled over the past century (Table 7.3a); a majority of which occurred within the latter half of the 1960-2009 period of record (Figure 7.4). Historically, these extreme events are most common in fall (see Kunkel et al., 2010) and spring and infrequent in winter.

Locally, observed changes in total annual and seasonal precipitation are consistent with regional patterns (Douglas and Fairbank, 2011; Agel et al., 2015; Kunkel et al., 2013; Hoerling et al., 2016; Easterling et al., 2017; Huang et al., 2017; Runkle et al., 2017). This includes significant increases in long-term total annual and fall precipitation, and increases more recently (since 1970) in summer. The summer season had the largest total increase over recent

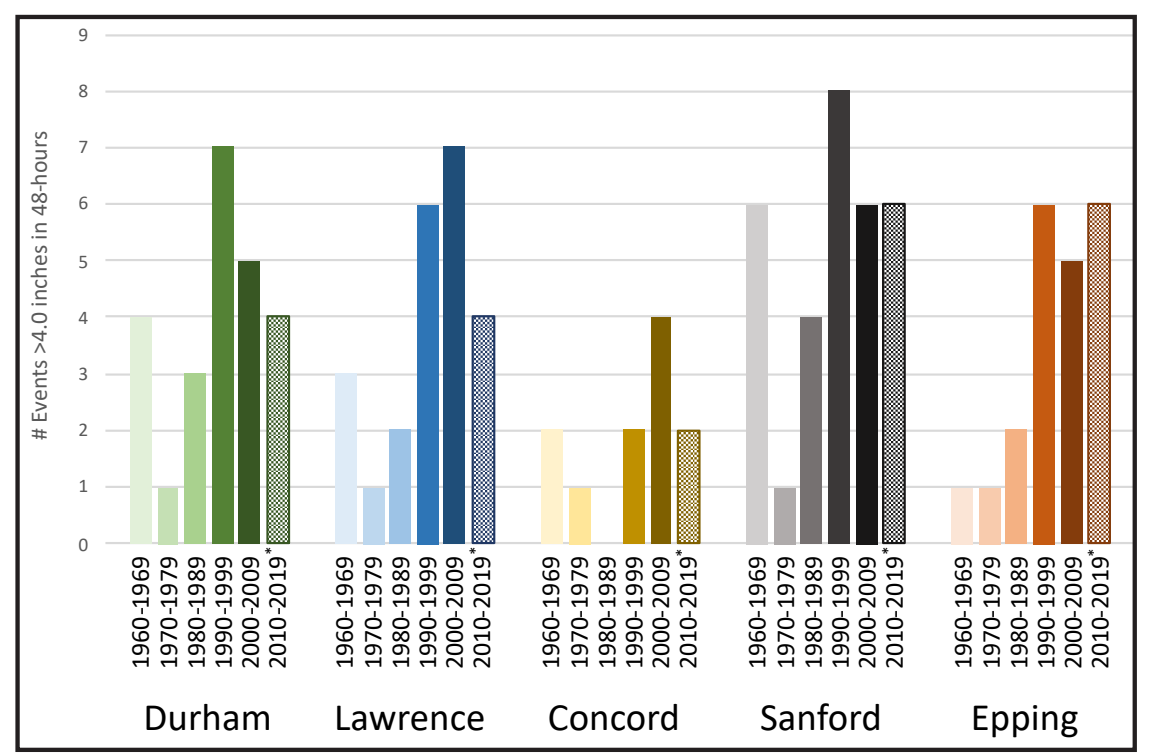

Figure 7.4. Number of extreme precipitation events (per decade) of 4" or more over two or more days since 1960. Data for the most recent decade (2010-2019*) is complete through 2018. 
decades and five of the 10 wettest summers on record occurred after 2004. In addition to extreme precipitation, recent years have been punctuated by periods of moderate (2010, 2012, 2013, and 2015) to extreme (2016) drought development during the warm season. At the same time, there was an observable, positive shift in the winter trend, which is consistent with the regional pattern (Huang et al., 2017) and projections for an increasing trend in winter precipitation throughout this century (Thibeault \& Seth 2014). Increases in total precipitation can be attributed in part to increases in extreme precipitation, including the frequency of extreme 1-day, 2-day, or longer events, all of which have increased regionally since the 1990s's (Hoerling et al., 2016; Huang et al., 2017). Results from Huang et al (2017) suggest that almost half of the extreme precipitation increase since 1996 is due to tropical cyclones, with fronts responsible for $25 \%$ of the increase, and extratropical cyclones accounting for $15 \%$ of the increase.

\subsection{PROJECTED FUTURE TRENDS IN PRECIPITATION}

Regional precipitation patterns projected through the end of this century indicate that overall annual precipitation and extreme precipitation events will continue to increase (Hayhoe et al. 2007 2008; Thibeault and Seth, 2014; Easterling et al., 2017). In addition, the seasonal distribution of precipitation is likely to change from the observed historical pattern (Lynch et al., 2016). For coastal New England, the largest seasonal increases are expected to shift from summer and fall to spring and winter. For example, winter and spring precipitation is projected to increase by $10-15 \%$ by the end of the $21^{\text {st }}$ century with little change in summer and fall under the growing greenhouse gas concentration scenario (RCP 8.5) (Easterling et al., 2017; Runkle et al., 2017). Seasonal differences may be due to an increase in cold season storm frequency and intensity by the end of the century (Colle et al.,
2013). The Northeast U.S. region is expected to see the largest increase in extreme precipitation event frequency of all U.S. regions (Janssen et al., 2016). A minimum increase of $10 \%$ over present day is expected by mid-century and an increase of more than $20 \%$ is likely by end of century under RCP 8.5 (Easterling et al., 2017; Hayhoe et al., 2017).

Table 7.4 presents a summary of simulated historical (1980-2005) and projected future (2006-2099) daily precipitation estimates for Durham, Concord, and Portsmouth, New Hampshire. These values represent the ensemble mean of the 29-member, high resolution (4 km) statistically downscaled Coupled Model Intercomparison Project (CMIP5) for representative concentration pathways (RCP) scenarios leading to lower (4.5 W m-2) and higher (8.5 W m-2) warming by end of century (Burakowski et al., 2019). Statistical downscaling was performed using localized constructed analogs (LOCA) (Pierce et al., 2014, 2015), the same technique used in the 2017 National Climate Assessment Climate Special Science Report (Castellano and DeGaetano, 2017; Easterling et al., 2017). Ensemble means are weighted following Sanderson et al. (2017). Overall, annual precipitation is expected to increase across the coastal watershed under both RCP's (Table 7.4).

Following the larger regional pattern (Thibeault and Seth, 2014; Easterling et al., 2017), annual precipitation in southeastern New Hampshire is projected to increase $5-10 \%$ by mid-century and $7-15 \%$ by the end of the $21^{\text {st }}$ century (Table 7.4). However, the projected increase in precipitation is not distributed uniformly throughout the year and is expected to be highest in winter (12 - 28\%; Figure 7.5). In general, the higher percentage change occurs for RCP 8.5 , although there is relatively little difference in the amount of annual and seasonal precipitation between the two greenhouse gas concentration scenarios. These results, consistent with previous findings (Hayhoe et al. 2007; Wake et al. 
Table 7.4. Projected $21^{\text {st }}$ century change in total annual, seasonal and extreme precipitation for (a) Concord, (b) Durham, and (c) Portsmouth NH from CMIP5 weighted means of daily precipitation output from 29 models. Projected change is calculated as the difference from, and percent of, the modeled 1980-2009 average for each 30-year time period. Percent change calculated as the difference divided by the historical average. Modeled value weights based on Sanderson et al. (2017).

\begin{tabular}{l|c|cc|c|c|c|}
\hline & \multicolumn{9}{c}{ Change from historical (+ or -) } \\
$\begin{array}{c}\text { Historical } \\
(1980-2009)\end{array}$ & $\begin{array}{c}\text { Short Term } \\
(2010-2039)\end{array}$ & $\begin{array}{c}\text { Medium Term } \\
(2040-2069)\end{array}$ & $\begin{array}{c}\text { Long Term } \\
\text { (2070-2099) }\end{array}$ \\
\cline { 2 - 7 } & RCP 4.5 & RCP 8.5 & RCP 4.5 & RCP 8.5 & RCP 4.5 & RCP 8.5 \\
\hline
\end{tabular}

\begin{tabular}{|c|c|c|c|c|c|c|c|}
\hline \multicolumn{8}{|c|}{$\begin{array}{l}\text { (a) Concord, NH } \\
\text { Precipitation in inches }\end{array}$} \\
\hline \multicolumn{8}{|l|}{ TOTAL } \\
\hline Annual & 39.94 & $\begin{array}{l}1.72 \\
(4 \%)\end{array}$ & $\begin{array}{l}1.79 \\
(4 \%)\end{array}$ & $\begin{array}{l}2.90 \\
(7 \%)\end{array}$ & $\begin{array}{c}3.91 \\
(10 \%)\end{array}$ & $\begin{array}{c}3.87 \\
(10 \%)\end{array}$ & $\begin{array}{c}5.91 \\
(15 \%)\end{array}$ \\
\hline Winter & 9.25 & $\begin{array}{l}0.76 \\
(8 \%)\end{array}$ & $\begin{array}{l}0.65 \\
(7 \%)\end{array}$ & $\begin{array}{c}1.06 \\
(11 \%)\end{array}$ & $\begin{array}{c}1.61 \\
(17 \%)\end{array}$ & $\begin{array}{c}1.61 \\
(17 \%)\end{array}$ & $\begin{array}{c}2.60 \\
(28 \%)\end{array}$ \\
\hline Spring & 9.98 & $\begin{array}{l}0.29 \\
(3 \%)\end{array}$ & $\begin{array}{l}0.51 \\
(5 \%)\end{array}$ & $\begin{array}{l}0.74 \\
(7 \%)\end{array}$ & $\begin{array}{c}1.02 \\
(10 \%)\end{array}$ & $\begin{array}{l}0.84 \\
(8 \%)\end{array}$ & $\begin{array}{c}1.83 \\
(18 \%)\end{array}$ \\
\hline Summer & 9.95 & $\begin{array}{l}0.49 \\
(5 \%)\end{array}$ & $\begin{array}{l}0.43 \\
(4 \%)\end{array}$ & $\begin{array}{l}0.70 \\
(7 \%)\end{array}$ & $\begin{array}{l}0.69 \\
(7 \%)\end{array}$ & $\begin{array}{c}0.98 \\
(10 \%)\end{array}$ & $\begin{array}{l}0.80 \\
(8 \%)\end{array}$ \\
\hline Fall & 10.76 & $\begin{array}{l}0.18 \\
(2 \%)\end{array}$ & $\begin{array}{l}0.20 \\
(2 \%)\end{array}$ & $\begin{array}{l}0.39 \\
(4 \%)\end{array}$ & $\begin{array}{l}0.58 \\
(5 \%)\end{array}$ & $\begin{array}{l}0.43 \\
(4 \%)\end{array}$ & $\begin{array}{l}0.69 \\
(7 \%)\end{array}$ \\
\hline PMAX & 2.18 & $\begin{array}{l}0.03 \\
(2 \%)\end{array}$ & $\begin{array}{l}0.06 \\
(3 \%)\end{array}$ & $\begin{array}{l}0.14 \\
(6 \%)\end{array}$ & $\begin{array}{l}0.18 \\
(9 \%)\end{array}$ & $\begin{array}{l}0.16 \\
(8 \%)\end{array}$ & $\begin{array}{c}0.29 \\
(13 \%)\end{array}$ \\
\hline \multicolumn{8}{|c|}{ Extreme Precipitation (events per year) } \\
\hline $1^{\prime \prime}$ in $24 \mathrm{hrs}$ & 7.1 & $\begin{array}{c}0.7 \\
(10 \%)\end{array}$ & $\begin{array}{c}0.8 \\
(11 \%)\end{array}$ & $\begin{array}{c}1.4 \\
(20 \%)\end{array}$ & $\begin{array}{c}2.0 \\
(29 \%)\end{array}$ & $\begin{array}{c}1.9 \\
(26 \%)\end{array}$ & $\begin{array}{c}3.1 \\
(44 \%)\end{array}$ \\
\hline \multicolumn{8}{|c|}{ Extreme Precipitation (events per decade) } \\
\hline $2^{\prime \prime}$ in $24 \mathrm{hrs}$ & 7.0 & $\begin{array}{c}0.6 \\
(9 \%)\end{array}$ & $\begin{array}{c}1.1 \\
(16 \%)\end{array}$ & $\begin{array}{c}1.6 \\
(22 \%)\end{array}$ & $\begin{array}{c}3.0 \\
(42 \%)\end{array}$ & $\begin{array}{c}2.8 \\
(40 \%)\end{array}$ & $\begin{array}{c}4.2 \\
(59 \%)\end{array}$ \\
\hline $4 "$ in $48 \mathrm{hrs}$ & 2.0 & $\begin{array}{c}0.7 \\
(35 \%)\end{array}$ & $\begin{array}{c}1.0 \\
(11 \%)\end{array}$ & $\begin{array}{c}1.0 \\
(51 \%)\end{array}$ & $\begin{array}{c}1.7 \\
(91 \%)\end{array}$ & $1.5(77 \%)$ & $\begin{array}{c}2.2 \\
(114 \%)\end{array}$ \\
\hline
\end{tabular}




\begin{tabular}{ccccccc}
\hline & \multicolumn{5}{c}{ Change from historical (+ or -) } \\
$\begin{array}{c}\text { Historical } \\
(1980-2009)\end{array}$ & $\begin{array}{c}\text { Short Term } \\
(2010-2039)\end{array}$ & $\begin{array}{c}\text { Medium Term } \\
(2040-2069)\end{array}$ & $\begin{array}{c}\text { Long Term } \\
\text { (2070-2099) }\end{array}$ \\
& RCP 4.5 & RCP 8.5 & RCP 4.5 & RCP 8.5 & RCP 4.5 & RCP 8.5 \\
\hline
\end{tabular}

\section{(b) Durham, NH}

Precipitation in inches

\begin{tabular}{|c|c|c|c|c|c|c|c|}
\hline \multicolumn{8}{|l|}{ TOTAL } \\
\hline Annual & 43.51 & $\begin{array}{l}1.41 \\
(3 \%)\end{array}$ & $\begin{array}{l}1.49 \\
(3 \%)\end{array}$ & $\begin{array}{l}2.35 \\
(5 \%)\end{array}$ & $\begin{array}{l}3.07 \\
(7 \%)\end{array}$ & $\begin{array}{l}3.07 \\
(7 \%)\end{array}$ & $\begin{array}{c}4.79 \\
(11 \%)\end{array}$ \\
\hline Winter & 10.56 & $0.64(6 \%)$ & $\begin{array}{l}0.47 \\
(5 \%)\end{array}$ & $\begin{array}{l}0.81 \\
(8 \%)\end{array}$ & $\begin{array}{c}1.40 \\
(13 \%)\end{array}$ & $\begin{array}{c}1.44 \\
(14 \%)\end{array}$ & $\begin{array}{c}2.34 \\
(22 \%)\end{array}$ \\
\hline Spring & 11.05 & $\begin{array}{l}0.32 \\
(4 \%)\end{array}$ & $\begin{array}{l}0.57 \\
(5 \%)\end{array}$ & $\begin{array}{l}0.74 \\
(7 \%)\end{array}$ & $\begin{array}{l}1.03 \\
(9 \%)\end{array}$ & $\begin{array}{l}0.84 \\
(8 \%)\end{array}$ & $\begin{array}{c}1.78 \\
(16 \%)\end{array}$ \\
\hline Summer & 9.88 & $\begin{array}{l}0.38 \\
(4 \%)\end{array}$ & $\begin{array}{l}0.38 \\
(4 \%)\end{array}$ & $\begin{array}{l}0.65 \\
(4 \%)\end{array}$ & $\begin{array}{l}0.35 \\
(4 \%)\end{array}$ & $\begin{array}{l}0.69 \\
(7 \%)\end{array}$ & $\begin{array}{l}0.46 \\
(5 \%)\end{array}$ \\
\hline Fall & 12.03 & $\begin{array}{l}0.08 \\
(1 \%)\end{array}$ & $\begin{array}{c}0.07 \\
(1 \%)\end{array}$ & $\begin{array}{l}0.14 \\
(1 \%)\end{array}$ & $\begin{array}{l}0.29 \\
(2 \%)\end{array}$ & $\begin{array}{l}0.10 \\
(1 \%)\end{array}$ & $\begin{array}{l}0.21 \\
(2 \%)\end{array}$ \\
\hline PMAX & 2.27 & $\begin{array}{l}0.19 \\
(9 \%)\end{array}$ & $\begin{array}{l}0.21 \\
(9 \%)\end{array}$ & $\begin{array}{c}0.24 \\
(10 \%)\end{array}$ & $\begin{array}{c}0.37 \\
(16 \%)\end{array}$ & $\begin{array}{c}0.35 \\
(15 \%)\end{array}$ & $\begin{array}{c}0.54 \\
(24 \%)\end{array}$ \\
\hline \multicolumn{8}{|c|}{ Extreme Precipitation in events per year } \\
\hline $1^{\prime \prime}$ in $24 \mathrm{hrs}$ & 6.5 & $\begin{array}{c}0.7 \\
(11 \%)\end{array}$ & $\begin{array}{c}0.8 \\
(12 \%)\end{array}$ & $\begin{array}{c}1.2 \\
(18 \%)\end{array}$ & $\begin{array}{c}1.6 \\
(24 \%)\end{array}$ & $\begin{array}{c}1.5 \\
(23 \%)\end{array}$ & $\begin{array}{c}2.5 \\
(38 \%)\end{array}$ \\
\hline \multicolumn{8}{|c|}{ Extreme Precipitation in events per decade } \\
\hline $2 "$ in $24 \mathrm{hrs}$ & 8.0 & $\begin{array}{c}1.2 \\
(15 \%)\end{array}$ & $\begin{array}{c}1.0 \\
(13 \%)\end{array}$ & $\begin{array}{c}2.0 \\
(25 \%)\end{array}$ & $\begin{array}{c}3.5 \\
(44 \%)\end{array}$ & $\begin{array}{c}3.2 \\
(40 \%)\end{array}$ & $\begin{array}{c}5.8 \\
(73 \%)\end{array}$ \\
\hline $4 "$ in $48 \mathrm{hrs}$ & 3.0 & $\begin{array}{c}1.2 \\
(38 \%)\end{array}$ & $\begin{array}{c}1.5 \\
(52 \%)\end{array}$ & $\begin{array}{c}1.8 \\
(60 \%)\end{array}$ & $\begin{array}{c}2.6 \\
(93 \%)\end{array}$ & $\begin{array}{c}2.1 \\
(69 \%)\end{array}$ & $\begin{array}{c}4.4 \\
(154 \%)\end{array}$ \\
\hline
\end{tabular}




\begin{tabular}{|c|c|c|c|c|c|c|}
\hline \multirow{3}{*}{$\begin{array}{l}\text { Historical } \\
(1980-2009)\end{array}$} & \multicolumn{6}{|c|}{ Change from historical (+ or - ) } \\
\hline & \multicolumn{2}{|c|}{$\begin{array}{l}\text { Short Term } \\
(2010-2039)\end{array}$} & \multicolumn{2}{|c|}{$\begin{array}{l}\text { Medium Term } \\
\text { (2040-2069) }\end{array}$} & \multicolumn{2}{|c|}{$\begin{array}{l}\text { Long Term } \\
\text { (2070-2099) }\end{array}$} \\
\hline & RCP 4.5 & RCP 8.5 & RCP 4.5 & RCP 8.5 & RCP 4.5 & RCP 8.5 \\
\hline
\end{tabular}

(c) Portsmouth, NH

Precipitation in inches

\begin{tabular}{|c|c|c|c|c|c|c|c|}
\hline \multicolumn{8}{|l|}{ TOTAL } \\
\hline Annual & 45.35 & $\begin{array}{l}1.33 \\
(3 \%)\end{array}$ & $\begin{array}{l}1.47 \\
(3 \%)\end{array}$ & $\begin{array}{l}2.34 \\
(5 \%)\end{array}$ & $\begin{array}{l}2.96 \\
(7 \%)\end{array}$ & $\begin{array}{l}2.98 \\
(7 \%)\end{array}$ & $\begin{array}{c}4.59 \\
(10 \%)\end{array}$ \\
\hline Winter & 11.69 & $\begin{array}{l}0.67 \\
(6 \%)\end{array}$ & $\begin{array}{l}0.49 \\
(4 \%)\end{array}$ & $\begin{array}{l}0.78 \\
(7 \%)\end{array}$ & $\begin{array}{c}1.40 \\
(12 \%)\end{array}$ & $\begin{array}{c}1.45 \\
(12 \%)\end{array}$ & $\begin{array}{c}2.33 \\
(20 \%)\end{array}$ \\
\hline Spring & 11.43 & $\begin{array}{l}0.24 \\
(2 \%)\end{array}$ & $\begin{array}{l}0.57 \\
(5 \%)\end{array}$ & $\begin{array}{l}0.73 \\
(6 \%)\end{array}$ & $\begin{array}{l}0.97 \\
(8 \%)\end{array}$ & $\begin{array}{l}0.76 \\
(7 \%)\end{array}$ & $\begin{array}{c}1.64 \\
(14 \%)\end{array}$ \\
\hline Summer & 9.68 & $\begin{array}{l}0.39 \\
(4 \%)\end{array}$ & $\begin{array}{l}0.40 \\
(4 \%)\end{array}$ & $\begin{array}{l}0.66 \\
(7 \%)\end{array}$ & $\begin{array}{l}0.34 \\
(3 \%)\end{array}$ & $\begin{array}{l}0.70 \\
(7 \%)\end{array}$ & $\begin{array}{l}0.41 \\
(4 \%)\end{array}$ \\
\hline Fall & 12.55 & $\begin{array}{l}0.03 \\
(0 \%)\end{array}$ & $\begin{array}{l}0.01 \\
(0 \%)\end{array}$ & $\begin{array}{l}0.18 \\
(1 \%)\end{array}$ & $\begin{array}{l}0.26 \\
(2 \%)\end{array}$ & $\begin{array}{l}0.07 \\
(1 \%)\end{array}$ & $\begin{array}{l}0.22 \\
(2 \%)\end{array}$ \\
\hline PMAX & 2.26 & $\begin{array}{l}0.14 \\
(6 \%)\end{array}$ & $\begin{array}{l}0.16 \\
(7 \%)\end{array}$ & $\begin{array}{l}0.19 \\
(8 \%)\end{array}$ & $\begin{array}{c}0.28 \\
(13 \%)\end{array}$ & $\begin{array}{c}0.24 \\
(11 \%)\end{array}$ & $\begin{array}{c}0.46 \\
(21 \%)\end{array}$ \\
\hline \multicolumn{8}{|c|}{ Extreme Precipitation in events per year } \\
\hline $1^{\prime \prime}$ in $24 \mathrm{hrs}$ & 6.3 & $\begin{array}{c}0.6 \\
(9 \%)\end{array}$ & $\begin{array}{c}0.7 \\
(11 \%)\end{array}$ & $\begin{array}{c}1.2 \\
(19 \%)\end{array}$ & $\begin{array}{c}1.6 \\
(25 \%)\end{array}$ & $\begin{array}{c}1.5 \\
(24 \%)\end{array}$ & $\begin{array}{c}2.5 \\
(39 \%)\end{array}$ \\
\hline \multicolumn{8}{|c|}{ Extreme Precipitation in events per decade } \\
\hline $2^{\prime \prime}$ in $24 \mathrm{hrs}$ & 8.8 & $\begin{array}{c}0.7 \\
(8 \%)\end{array}$ & $\begin{array}{c}1.4 \\
(17 \%)\end{array}$ & $\begin{array}{c}1.9 \\
(21 \%)\end{array}$ & $\begin{array}{c}3.1 \\
(36 \%)\end{array}$ & $\begin{array}{c}2.6 \\
(30 \%)\end{array}$ & $\begin{array}{c}5.9 \\
(69 \%)\end{array}$ \\
\hline $4^{\prime \prime}$ in $48 \mathrm{hrs}$ & 2.9 & $\begin{array}{c}1.1 \\
(36 \%)\end{array}$ & $\begin{array}{c}1.2 \\
(44 \%)\end{array}$ & $\begin{array}{c}1.6 \\
(56 \%)\end{array}$ & $\begin{array}{c}2.3 \\
(82 \%)\end{array}$ & $\begin{array}{c}1.9 \\
(64 \%)\end{array}$ & $\begin{array}{c}3.5 \\
(124 \%)\end{array}$ \\
\hline
\end{tabular}


2014; Easterling et al., 2017) indicate that the coastal watershed, and much of New England, will experience a modest increase in the amount of precipitation over the $21^{\text {st }}$ Century.

The projected change in extreme precipitation events shows a larger increase (Table 7.4) compared to the annual and seasonal change. For example, an 8-18\% increase under RCP 4.5 and $13-24 \%$ increase under RCP8.5 by end the end of the century is projected for the amount of precipitation falling on the wettest day of the year (Figure 7.6a). The number of 1-day events that produce one inch is projected to increase $23-26 \%$ under RCP 4.5 and $38-44 \%$ under RCP 8.5, with greater increases in two inch events under both scenarios by the end of the century. The largest increases

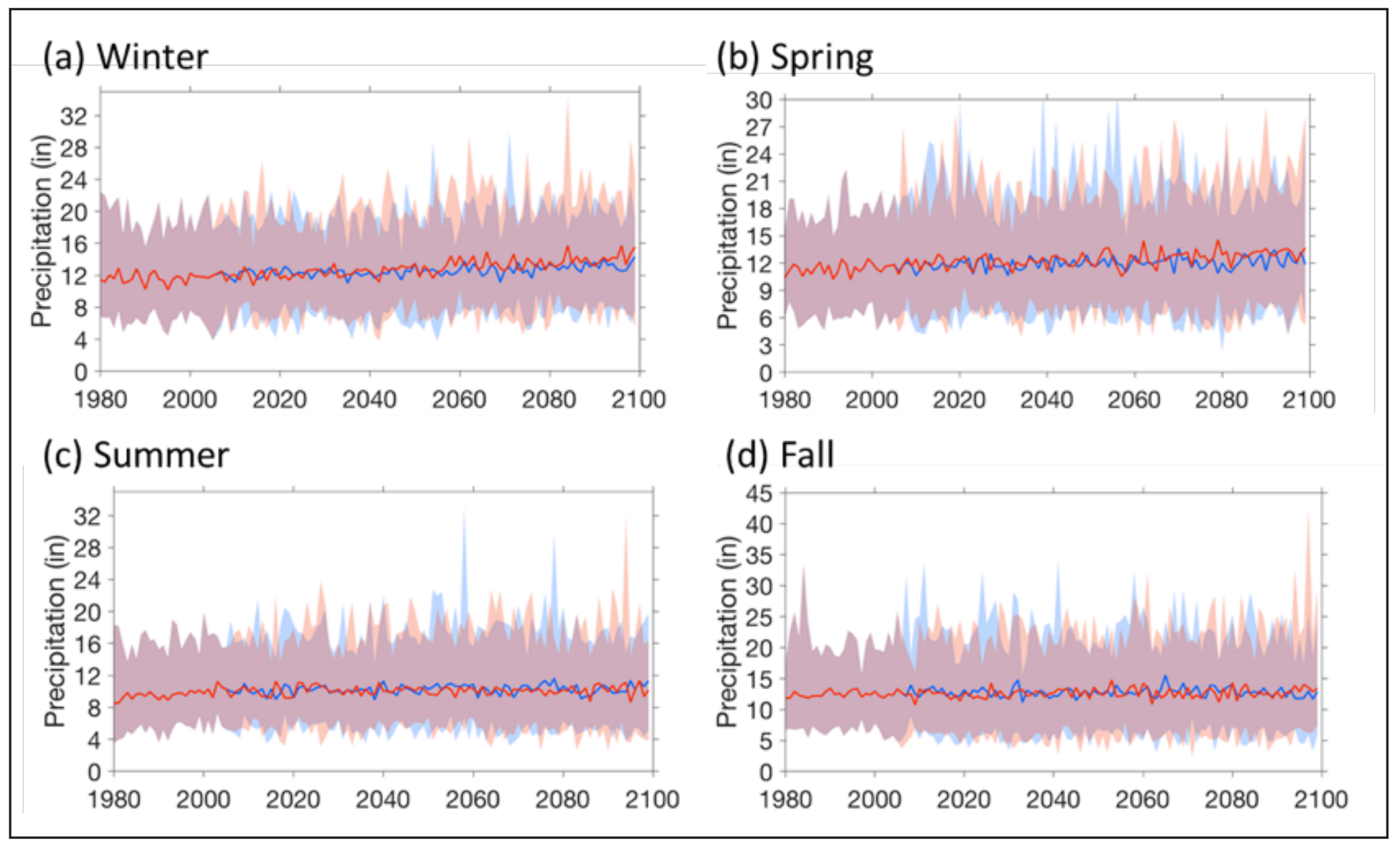

Figure 7.5. CMIP5 mean modeled historical (1980-2005) and projected future (2006-2099) total seasonal at Portsmouth, NH for (a) winter, (b) spring, (c) summer, and (d) fall for RCP4.5 (blue) and RCP8.5 (red) (from Burakowski et al., 2019.) Ensemble means are weighted following Sanderson et al. (2017). 

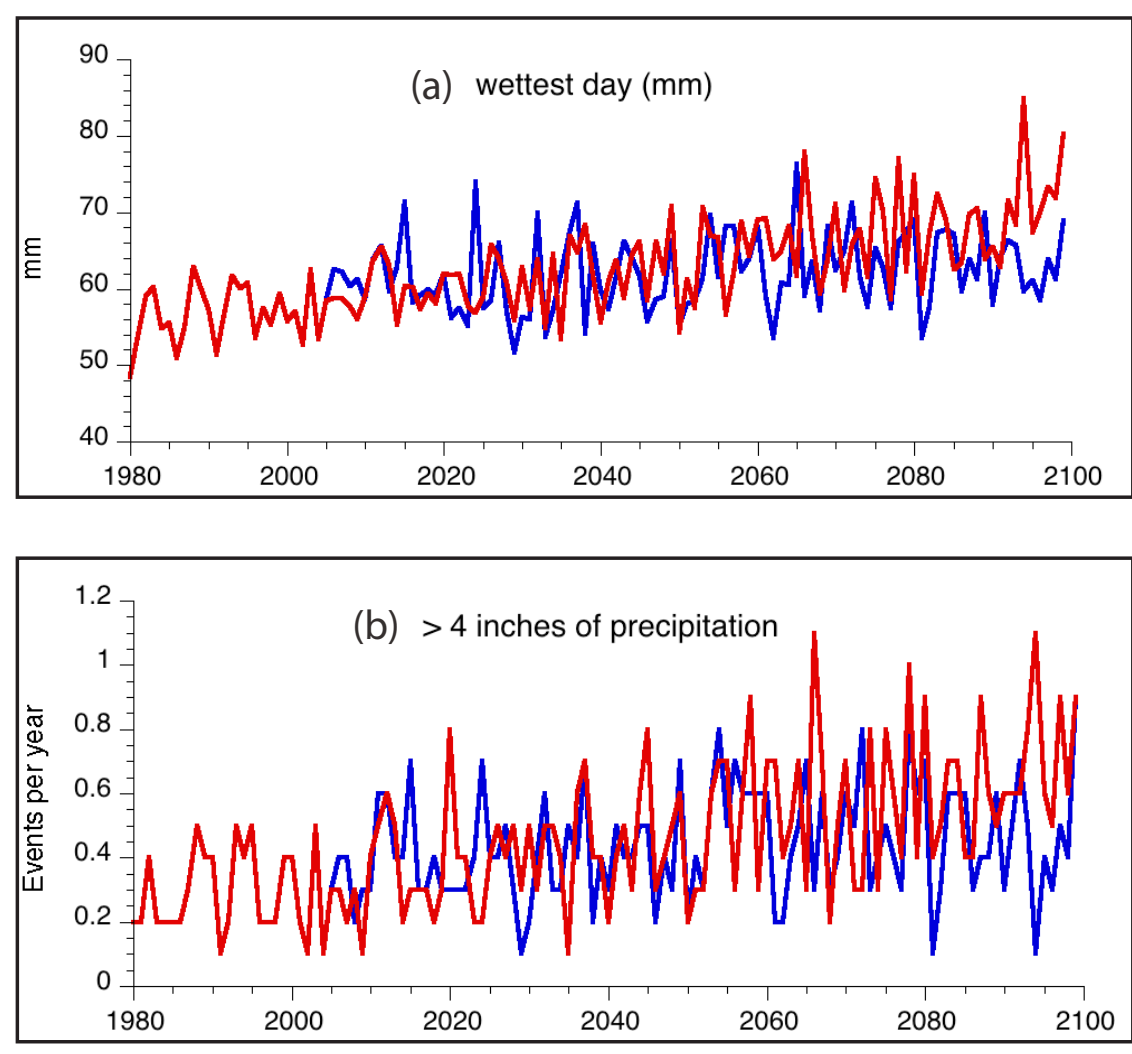

Figure 7.6. CMIP5 mean modeled historical (1980-2005) and projected future (2006-2099) for (a) annual maximum daily precipitation and (b) events greater than 4" at Portsmouth, $\mathrm{NH}$ under RCP4.5 (blue) and RCP8.5 (red) (from Burakowski et al., 2019). Ensemble means are weighted following (Sanderson et al., 2017) are projected for 2-day storm totals exceeding four inches (114$154 \%$ ) by the end of the century under RCP 8.5 (Figure 7.6b).

\subsection{PRECIPITATION EMERGING ISSUES}

As described in Section 7.4, the observed increases in total annual and seasonal precipitation are attributed to an increase in the intensity and frequency of individual precipitation events (Kunkel et al., 2013; Guilbert et al., 2015; Easterling et al., 2017). Recently updated daily point extreme precipitation estimates for the Great Bay watershed show a 15-38\% increase in the magnitude of extreme daily precipitation compared to mid-20th century estimates (Table 7.2). As precipitation intensity continues to increase, the frequency of extreme daily precipitation events $(>=1$ inch in 24 hours) are also projected to increase across the Great Bay watershed (Thibeault and Seth, 2014; Easterling et al., 2017).

Given the expected increases in the magnitude and frequency of daily precipitation extremes, estimates for projected changes in the intensity, frequency, and duration of extreme precipitation at sub-daily time scales are needed for the design and maintenance of water systems and transportation infrastructure (Fadhel et al., 2017). These sub-daily model simulations have recently been completed for the northeast US (Komurcu et al., 2018) and analysis of this output should be included in the next assessment. Historical and projected point estimate Intensity-DurationFrequency (IDF) curves for the Great Bay region were not included in this report but given the practical applications of IDF curves, it is recommended they be included in future reports. 


\section{FRESHWATER FLOODING}

\subsection{KEY FINDINGS}

FWF 1. Freshwater flooding in coastal New Hampshire has increased in magnitude and frequency.

The magnitude and frequency of freshwater floods in New Hampshire's coastal watershed have increased over the past four decades in response to both climate change and development that has led to an increase in impervious surface.

FWF 2. Freshwater flooding is expected to increase in the future.

Analysis of historical floods shows that extreme precipitation events are only loosely correlated with runoff and flood damage. Projecting future flooding depends fundamentally on accurately projecting antecedent conditions (e.g., soil moisture, snowpack, reservoir storage) which presents a significant challenge. However, three separate research projects that have projected future flooding in coastal New Hampshire have all concluded that we should expect an increase in floods in the future, both as a result of climate change and land use change driven by development pressure.

\subsection{CHANGES FROM 2014 STAP REPORT}

- Past and potential future changes in freshwater flooding were not included in the 2014 STAP Report.

\subsection{UNDERSTANDING FRESHWATER FLOODING}

Historical settlement patterns along rivers places many of New Hampshire's communities at risk of flooding, the costliest and most frequent natural hazard for New Hampshire (Figure 8.1) and for New England more broadly. Flooding events account for $60 \%$ of New Hampshire's presidentially declared disasters and emergency declarations and $67 \%$ of the federal reimbursement provided by FEMA for those disasters and declarations (FEMA, 2019). 


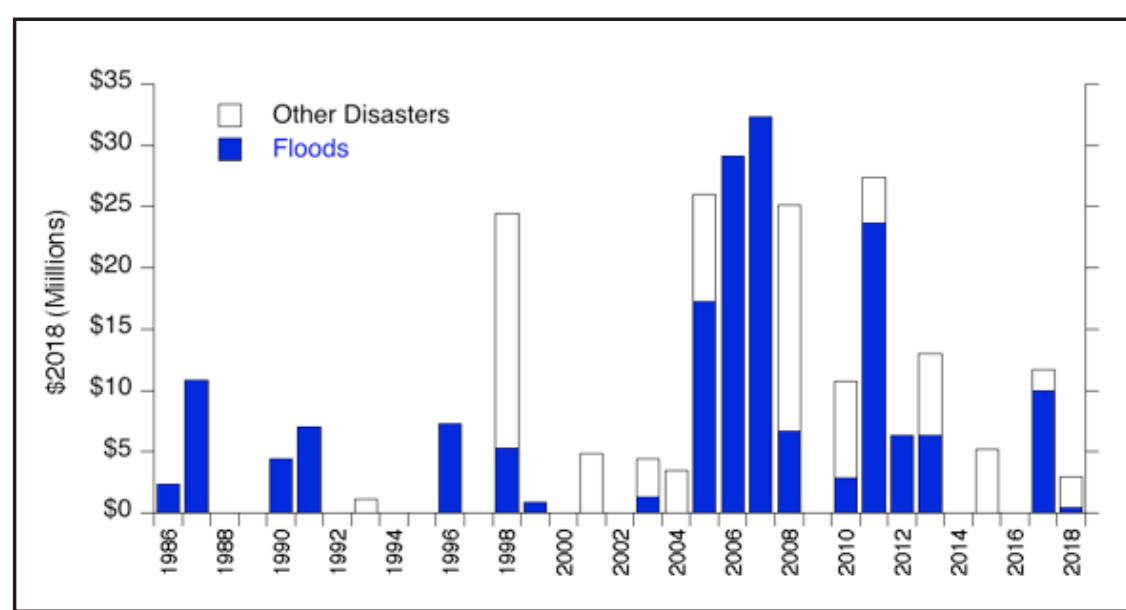

Figure 8.1. Federal expenditures on all presidentially declared disasters and emergency declarations for flood and flood-related events (blue bars) and all other disasters (white bars) in New Hampshire from 1986-2018, in 2018 dollars. Source: Data from FEMA (2019).

While coastal flooding is expected to increase with rising sea levels and changing storm surge (Chapter 4 and 5), riverine (aka freshwater) flooding is also expected to increase in response to increases in extreme precipitation events in the northeast US (e.g., Chapter 7, Hayhoe et al., 2007; Douglas and Fairbank, 2011; Guilbert et al., 2015, Demaria et al. 2016, Easterling et al. 2017). In addition, coastal watersheds in southeastern New England have experienced the greatest urban expansion in the northeast US since 1975 (Torbick and Corbierea, 2015), and there remains significant development pressure in many watersheds across all of New England (Stein et al., 2009; Dupigny-Girouz et al., 2018).

Changes in flood frequency and magnitude depend upon a combination of factors, including precipitation (amount, type, intensity), antecedent conditions (e.g., soil moisture, snowpack, reservoir storage), and land use and land cover. As a result, large precipitation events do not necessarily lead to high river discharges (e.g., Ivancic and Shaw, 2015). Analysis of historical precipitation and discharge observations from across New
England illustrate the complexity of predicting hydrologic flood response to extreme precipitation events as storm intensity is only loosely correlated with runoff and flood damage (Figure 8.2). Furthermore, the same precipitation event can cause drastically different flood events in different locations across a region due to the large spatial variability in antecedent conditions (Woldemeskel and Sharma, 2016). Many historical New England flood events were preceded by wet conditions (Paulson et al., 1991), because saturated soils (Dunne and Black, 1970) or other subsurface stores (McDonnell, 2013) maximize runoff and river discharge during storm events. In a detailed review of the

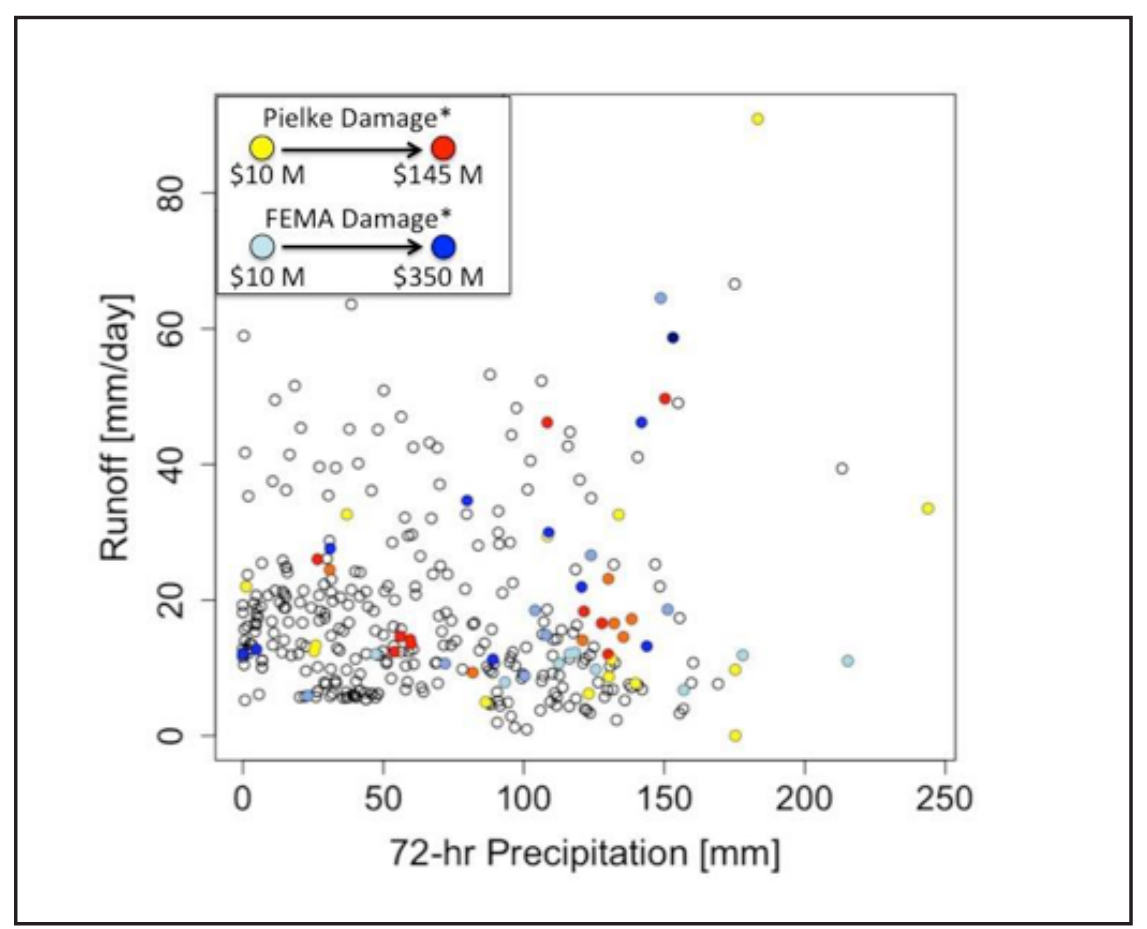

Figure 8.2. Seventy-two-hour precipitation plotted against runoff for the largest precipitation and flood events (80th percentile) across New England between 1980-2016. Flood damage estimates (filled circles) from Pielke (2002) and FEMA (2016). No relationship exists between precipitation, runoff, and damage. *Damage estimates not comparable between sources. Source: Adapted from Wake et al. (2017). 
generating mechanisms for floods in New England, Collins et al. (2014) conclude that the greatest number of annual floods occur during the late winter/early spring and that the dominant flood producing mechanism is rainfall (linked to nor'easters and GreatLakes sourced storms), although rainfall combined with snowmelt also represents an important mechanism for generating floods. Furthermore, despite causing some of the region's largest floods, tropical cyclones account for a relatively small proportion of all floods in the region.

A few studies have concluded that maximum streamflows across New England and the Northeast US have remained the same or decreased in recent decades (Douglas et al., 2000; McCabe and Wolock 2002; Lins and Slack 2005; Small et al., 2006; Villarini and Smith, 2010; Slater and Villarini, 2016). Small et al. (2006) explained this paradox (i.e., increased precipitation but no increase in high streamflows) in the eastern US by noting that "precipitation is increasing during the fall but not during the spring, the season when high flows are generally observed". This is the case for New Hampshire's coastal watershed which has experienced the largest increase in precipitation during the fall compared to weak and variable trends in the amount of spring precipitation (Table 7.1).

Several other New England specific studies have found an increase in maximum streamflow. An analysis of flow records for New England watersheds that exhibit minimal human influence concluded that flood magnitudes have increased since 1970 (Collins, 2009). Hodgkins (2010) analyzed 28 long-term stream gage records across Maine and found an increase in peak flows. Additional studies on rivers with minimal human impact confirmed that the magnitude and frequency of floods across New England are increasing (Armstrong et al., 2012; 2014). Frei et al. (2015) find that extreme streamflow events are increasing over the northeast US, especially during the warm season, caused primarily by an increase in frequency of events. Marini et al. (2016) analyzed daily streamflow data and found that maximum streamflows displayed more variability in recent decades in New England and an increasing trend in annual maximum flows in coastal New England.

\subsection{HISTORICAL TRENDS IN FRESHWATER FLOODING IN NEW HAMPSHIRE'S COASTAL WATERSHED}

There are several lines of evidence that indicate peak discharge in New Hampshire's coastal watershed has increased over the past several decades. Data from the United States Geological Survey (USGS) stream gages on the Lamprey and Oyster rivers provide the longest daily discharge records in the coastal New Hampshire watershed (1934 to present; Figure 8.3).

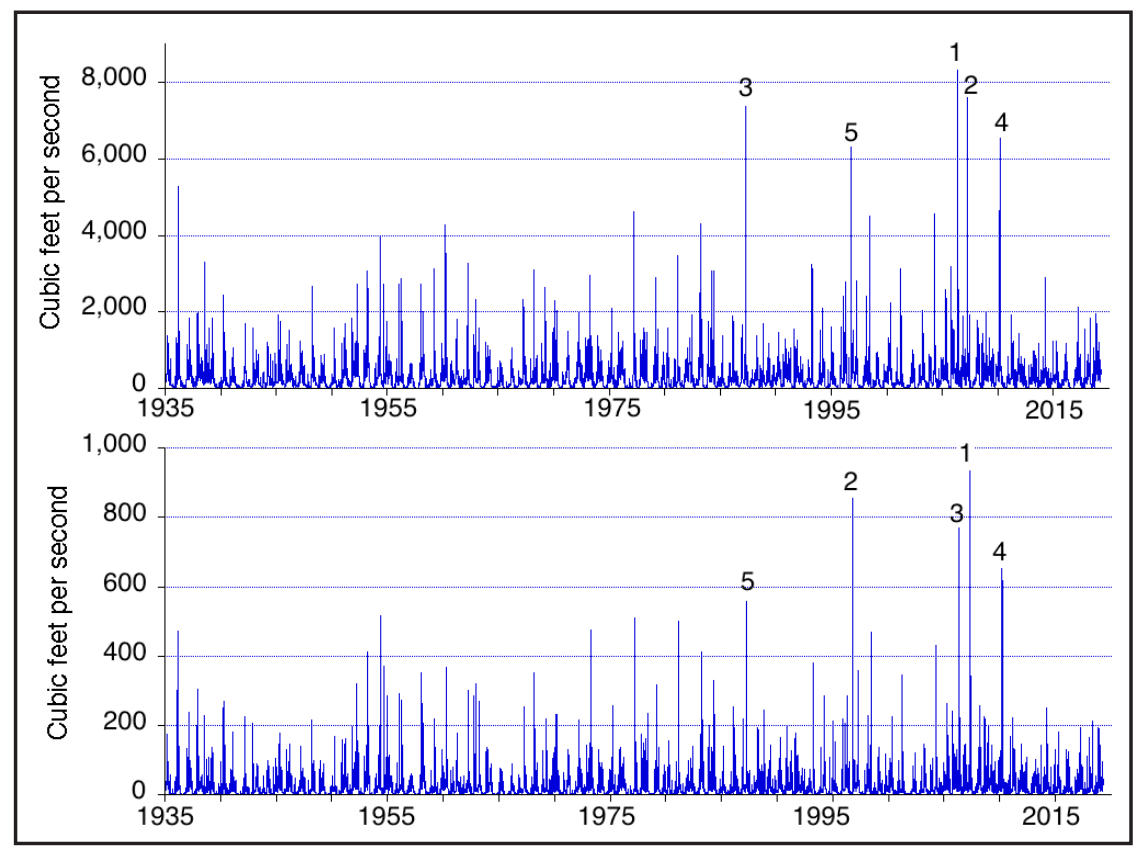

Figure 8.3. Daily peak discharge for the Lamprey River at USGS gage 01073500 (top) and the Oyster River USGS gage 01073000 (bottom) from 1934 through April 2019 (USGS, 2019). Note the largest five floods (ranked one through five for each record) on both rivers have occurred since 1986 (flood dates listed in Table 8.1). 
The five largest daily mean discharge events on both rivers have occurred since 1986 (Table 8.1), and the majority of those largest events ( 6 out of 10 ) have occurred since 2007. Note that four of the five highest daily discharges on both rivers have occurred in the spring or late winter. Analysis of recent observations shows that in the period between 2005 and 2015, flood magnitude increased between $14 \%$ and $56 \%$ on the Lamprey River (depending on return period for the flood) and between $17 \%$ and $40 \%$ on the Oyster River (depending on the return period for the flood) (Table 8.2; FEMA, 2005a; 2015).
Of the 72 Hydro-Climatic Data Network (HCDN) stream gages in New England, only the Oyster River in Durham, New Hampshire is in the coastal New Hampshire watershed. Nine of the 10 highest peak flows recorded for the Oyster River at the Durham, New Hampshire station (1935-2017) occurred since 1970, indicating that annual peak discharge has increased over the past 50 years. Statistical analyses of annual peak streamflow (USIAC, 1982) for 1964-2017 show a statistically significant increase in peak flood magnitude over the latter part of the record (Figure 8.4). Similarly,

Table 8.1. Daily mean discharge in cubic feet per second (cfs) for the five largest events measured on the Lamprey (USGS gage 01073500) and Oyster (USGS gage 01073000) rivers.

\begin{tabular}{|c|c|c|c|c|}
\hline $\begin{array}{c}\text { Rank } \\
\text { (Figure 8.3) }\end{array}$ & \multicolumn{2}{|c|}{ Lamprey River } & \multicolumn{2}{|c|}{ Oyster River } \\
\hline 1 & 16-May-2006 & $8400^{*}$ & 16-Apr-2007 & 942 \\
\hline 3 & 7-Apr-1987 & 7360 & 14-May-2006 & 768 \\
\hline 4 & 16-Mar-2010 & 6550 & 26-Feb-2010 & 653 \\
\hline
\end{tabular}

* Multi-day flood event; mean discharge on 15 May was 7600 cfs and on 17 May was 6240 cfs.

Table 8.2. Difference in the 2005 and 2015 FEMA Flood Insurance Studies (FIS) estimated 1\% (100-yr), 2\% (50-yr), and 10\% (10-yr) annual chance peak discharge between for the Lamprey River and Oyster River.

\begin{tabular}{|c|c|c|c|c|c|c|c|c|c|}
\hline \multirow{2}{*}{ River } & \multicolumn{3}{|c|}{ Peak Discharge (cfs) } & \multicolumn{3}{c|}{ Peak Discharge (cfs) } & \multicolumn{3}{c|}{ Peak Discharge (cfs) } \\
\cline { 2 - 11 } & 2005 & 2015 & Diff. & 2005 & 2015 & Diff. & 2005 & 2015 & Diff. \\
& $10-y r$ & $10-y r$ & $10-y r$ & $50-y r$ & $50-y r$ & $50-y r$ & $100-y r$ & $100-y r$ & $100-y r$ \\
\hline Lamprey $^{*}$ & 4120 & 4690 & $14 \%$ & 6270 & 9750 & $56 \%$ & 7300 & 9690 & $33 \%$ \\
\hline Oyster** $^{*}$ & 545 & 640 & $17 \%$ & 777 & 1030 & $33 \%$ & 879 & 1230 & $40 \%$ \\
\hline
\end{tabular}

*at Wiswall Dam (184 sq. mile drainage area)

**at USGS gage 01073000 (12.3 sq. mile drainage area) 
the peak discharge thresholds for 10, 25, 50, and 100-year return period flows increased for each decade since 1980 (Table 8.3, 8.4).

\subsection{PROJECTED FUTURE TRENDS IN FRESHWATER FLOODING}

Acknowledging the importance of antecedent conditions, several studies have projected that peak streamflows will increase in the coastal $\mathrm{NH}$ watershed in the future due climate change, including more extreme precipitation events, combined with an increase in impervious cover from land development.

One of the original studies to explore potential hydrological changes in the northeast US (Hayhoe et al. 2007) used global climate model simulations from the IPCC Fourth Assessment Report (IPCC, 2007) to drive the Variable Infiltration Capacity (VIC) hydrological model. Their results suggest climate change is likely to drive a redistribution of streamflow with higher flows in winter and spring, and lower flows in summer and fall. In addition, the probability of higher winter flows is expected to increase substantially (20-70\%, with a larger increase under a higher emissions scenario). Demaria et al. (2016) also used the VIC hydrological model driven by CMIP5 global climate model simulations for RCP4.5 and RCP 8.5 to explore streamflow projections in the northeast U.S. for the period 2028-2082. They found that the magnitude of 3-day peak flows across New England, and especially in coastal New Hampshire, are likely to increase and that this increase might be due to an increase in intense precipitation events in the future.

The potential for future flood risk along the main stem of the Lamprey River due to changes in climate and land cover has been modeled using the Hydrologic Engineering Center - Hydrologic Modeling System (HEC-HMS) (USACE, 2008) and HEC-GeoHMS (USACE 2001, 2008, 2009b). A relatively simple curve number reduction method (McCuen, 1983; MDE, 2009) was used to model

Table 8.3. Flood peak (cubic feet per second) estimates for the Oyster River at selected dates. Return interval flood magnitude estimates based on the Bulletin 17B methods (Log Pearson Type III distribution).

\begin{tabular}{|c|c|c|c|c|c|}
\hline Year & 1970 & 1980 & 1990 & $\mathbf{2 0 0 0}$ & $\mathbf{2 0 1 7}$ \\
\hline Q10 & 517 & 516 & 540 & 615 & 730 \\
\hline Q25 & 615 & 627 & 662 & 849 & 997 \\
\hline Q50 & 683 & 709 & 752 & 972 & 1192 \\
\hline Q100 & 746 & 788 & 841 & 972 & \\
\hline
\end{tabular}

Table 8.4. Increases in the Table F3 predicted flood flows different return periods as a percentage of the 1970 predicted flood flow (1980-2017).

\begin{tabular}{|c|c|c|c|c|c|}
\hline Year & 1970 & $\mathbf{1 9 8 0}$ & $\mathbf{1 9 9 0}$ & $\mathbf{2 0 0 0}$ & $\mathbf{2 0 1 7}$ \\
\hline Q10 & - & $0 \%$ & $4 \%$ & $12 \%$ & $19 \%$ \\
\hline Q25 & - & $2 \%$ & $8 \%$ & $24 \%$ & $34 \%$ \\
\hline Q50 & - & $4 \%$ & $10 \%$ & $30 \%$ & $60 \%$ \\
\hline Q100 & - & $6 \%$ & $13 \%$ & $30 \%$ \\
\hline
\end{tabular}




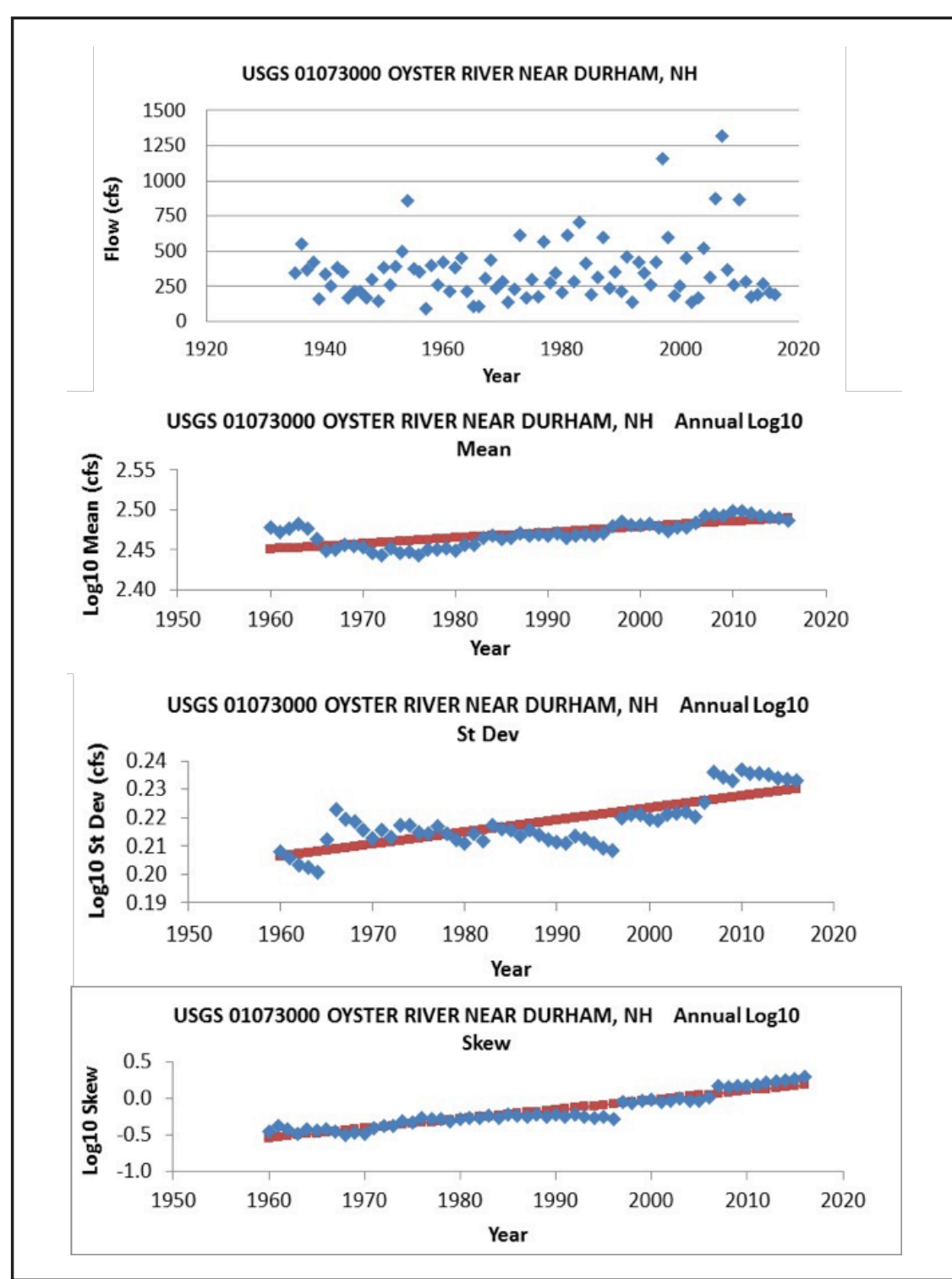

Figure 8.4. Oyster River in Durham, NH (a) observed annual peak flow (1935-2017). Annual peak streamflow statistics were calculated using the methods delineated in Bulletin $17 \mathrm{~B}$ (USIAC, 1982) for the (b) mean, (c) standard deviation, and (d) skew of computed annual log 10 peak discharge (1964-2017). The blue markers are the annual values and the red markers are the least-squares fitted linear trendlines. The slopes for each these trendlines are all statistically significant at the 99\% level (Mann-Whitney 1947). changes in impervious surface area resulting from projected development within the Lamprey River watershed (Scholz, 2011). The results show that the 100-year floodplain and associated peak flood water discharge have increased significantly from the 1950s to 2000s and will continue to increase in the future. For example, water discharge associated with 100-year flood is projected to increase $66 \%$ and the elevation of the 100 -year flood discharge is projected to increase 4.4 feet between 20052100 under a high emissions climate scenario and aggressive buildout of the Lamprey River Watershed (Scholz, 2011; Wake et al., 2013). This initial modeling was updated and used to explore the potential economic impacts of flooding on the main stem of the Lamprey River using the Federal Emergency Management Agency's Hazards-United States (Hazus) model (FEMA, 2012). The results (Geosyntec Consultants, 2016) confirm previous findings regarding future increases in discharge and flood inundation area resulting from climate change and development within the watershed, and also conclude that potential economic losses in communities along the Lamprey River from future floods will likely increase as well.

Bjerklie and Sturtevant $(2017 \mathrm{a}, \mathrm{b})$ used the USGS watershed model Precipitation Runoff Modeling System (PRMS) to simulate daily streamflow records for New Hampshire using daily simulated air temperature and precipitation from five different global climate model (GCM) simulations for the RCP 4.5 and 8.5 scenarios. They find that mean annual streamflow is likely to increase by mid$21^{\text {st }}$ century for all GCM input data sets tested. The increases are primarily during late fall, winter, and spring, with decreasing mean streamflows in summer and early fall. There is likely to be more frequent flood flows; however, the magnitude of the large floods may not appreciably increase even though mean streamflows are projected to increase. By the end of the century, the RCP 
8.5 scenario for some of the GCM input data sets showed mean annual streamflows beginning to decrease, due to increases in evapotranspiration outpacing increases in precipitation. These results are consistent with previous work by Bjerklie et al. (2015).

Two other findings from the Bjerklie and Sturtevant (2018) study are important for our understanding of coastal flood risk in the future. They found that groundwater recharge is projected to increase in coastal areas in $\mathrm{NH}$. In addition, they explored the sensitivity of their findings to increases in impervious surfaces in NH's coastal region. They find a 30\% increase in mean streamflow in the Exeter and Oyster Rivers resulting from a doubling of impervious surfaces in the watersheds with the increase in mean streamflow caused by larger high streamflows. In addition, there was a 5-10\% reduction in recharge which would result in lower baseflows.

Large storm surge events in coastal $\mathrm{NH}$ resulting from tropical or extratropical storms are often accompanied by large precipitation events. When these two phenomena are combined, the potential for flooding (termed 'compound flooding') can be much greater (Wahl et al., 2015). One important area of additional research should focus on the interaction among RSLR, storm surge, and heavy precipitation on flooding in the Great Bay Estuary. For example, the estimated 100-year discharge for the five largest rivers flowing into Great Bay and Little Bay total 31,008 cfs (Table 8.5). If we assume this peak flow continued for 24 hours (unlikely, but this provides an upper estimate) total discharge from these five rivers would be 2,679 million cubic feet. This is about $70 \%$ of the total volume of water in Great Bay and Little Bay above Dover Point at high tide (3,814 million cubic feet; Swift and Brown, 1983; Trowbridge, 2007), suggesting that compound flooding could be significant not only at the freshwater/tidal interface in tributaries that feed into Great Bay, but also for other areas of the Great Bay Estuary, such as the Route 16 corridor in Dover Point. Future versions of NOAA's National Water Model (https:// water.noaa.gov/about/nwm) are expected to provide coupled terrestrial and coastal estuary modeling capabilities that could be useful for exploring projections of compound flooding in Great Bay under different scenarios of RSLR, storm surge, and extreme precipitation events.

Table 8.5. Estimated 100-year discharge for rivers flowing into Great Bay and Little Bay (from FEMA, 2008) and potential discharge into Great Bay and Little Bay over 24 hours.

\begin{tabular}{|c|c|c|}
\hline River & Peak Dishcarge (cfs) & 24 hr discharge (million ft3) \\
\hline Cocheco & 11,100 & 959 \\
\hline Oyster & 1,220 & 812 \\
\hline Lamprey & 9,400 & 737 \\
\hline Exeter & 8,530 & 65 \\
\hline Winnicut & 758 & 2,679 \\
\hline TOTAL & 31,008 & 25 \\
\hline
\end{tabular}




\section{REFERENCES}

Agel, L., Barlow, M., Qian, J.H., Colby, F., Douglas, E., \& Eichler, T. (2015). Climatology of Daily Precipitation and Extreme Precipitation Events in the Northeast United States. Journal of Hydrometeorology, 16, 2537-2557. doi: https://doi.org/10.1175/JHM-D-14-0147.1

Amador, J.A., Görres, J.H., Loomis, G.W., \& Lancellotti, B.V. (2018). Nitrogen Loading from Onsite Wastewater Treatment Systems in the Greater Narragansett Bay (Rhode Island, USA) Watershed: Magnitude and Reduction Strategies. Water, Air and Soil Pollution, 229: 65. doi: https://doi.org/10.1007/s11270-018-3714-4

Anderson, N. (2016). Rye uses residents to help fix'Stinky Creek'. SeacoastOnline. Retrieved from http://www.seacoastonline.com/article/20160110/NEWS/1601199677.

Anderson, W. \& Emanuel, R. (2010). Effect of Interannual Climate Oscillations on Rates of Submarine Groundwater Discharge. Water Resources Research, 46, W05503. doi: https://doi.org/10.1029/2009WR008212

Arctic Monitoring and Assessment Programme (AMAP, 2017). Snow, Water, Ice and Permafrost in the Arctic (SWIPA) https://www.amap.no/documents/doc/snow-water-ice-and-permafrost-in-the-arcticswipa-2017/1610

Armstrong, W.H., Collins, M.J. \& Snyder, N.P. (2012). Increased Frequency of Low-Magnitude Floods in New England. Journal of the American Water Resources Association, 48:2. doi: https://doi.org/10.1111/j.1752-1688.2011.00613.x.

Armstrong W.H., Collins, M.J., \& Snyder, N.P. (2014). Hydroclimatic Flood Trends in the Northeastern United States and Linkages with Large-Scale Atmospheric Circulation Patterns. Hydrological Sciences Journal, 59:2, 1636-1655. https://doi.org/10.1080/02626667.2013.862339.

Ballestero, T.P., Roseen, R., \& Brannaka, L.K. (2004). Inflow and Loadings from Groundwater to the Great Bay Estuary, New Hampshire. PREP Reports \& Publications, 399. https://scholars.unh.edu/prep/399

Bamber, J.L., Westaway, R.M., Marzeion, B., \& Wouters, B. (2018). The Land Ice Contribution to Sea Level During the Satellite Era. Environmental Research Letters, 13:6, 063008. doi: https://doi.org/10.1088/1748-9326/aac2fo.

Bamber J.L., Oppenheimer, M., Kopp, R.E., Aspinall, W.P., Cook, R.M. (2019). Ice Sheet Contributions to Future Sea-Level Rise from Structured Expert Judgment. PNAS, 116:23, 11195-11200. doi: https://doi.org/10.1073/pnas.1817205116.

Barker, G. (2016), GEOLOGS, New Hampshire Geological Survey, New Hampshire Department of Environmental Services.

Behar, D., Kopp, R., DeConto, R., Weaver, C., White, K., May, K., \& Bindschadler, R. (2017). Planning for Sea Level Rise: An AGU Talk in the Form of a Co-Production Experiment Exploring Recent Science. https://www.wucaonline.org/assets/pdf/pubs-agu-consensus-statement.pdf

Berg, C.E., Mineau, M.M., \& Rogers, S.H. (2016). Examining the Ecosystem Service of Nutrient Removal in a Coastal Watershed. Ecosystem Services, 20, 102-112. doi: https://doi.org/10.1016/j.ecoser.2016.06.007. 
Bjerklie, D.M., Mullaney, J.R., Stone, J.R., Skinner, B.J., \& Ramlow, M.A. (2012). Preliminary Investigation of the Effects of Sea-Level Rise on Groundwater Levels in New Haven, Connecticut: U.S. Geological Survey Open-File Report, 2012-1025, 46p., http://pubs.usgs.gov/of/2012/1025/.

Bjerklie, D.M., Ayotte, J.D., \& Cahillane, M.J. (2015). Simulating Hydrologic Response to Climate Change Scenarios in Four Selected Watersheds of New Hampshire: U.S. Geological Survey Scientific Investigations Report 2015-5047, 53 p., http://dx.doi.org/10.3133/sir20155047.

Bjerklie, D.M., \& Sturtevant, L. (2017a). Thirty- and Ninety-Year Data Sets of Streamflow, Groundwater Recharge, and Snowfall Simulating Potential Hydrologic Response to Climate Change in the $21^{\text {st }}$ Century in New Hampshire: U.S. Geological Survey data release, https://doi.org/10.5066/F76TOKJZ.

Bjerklie, D.M., \& Sturtevant, L. (2017b). Simulated Hydrologic Response to Climate Change During the $21^{\text {st }}$ Century in New Hampshire: U.S. Geological Survey Scientific Investigations Report 2017-5143, 53 p. https://doi.org/10.3133/sir20175143.

Bloetscher, F., Polsky, C., Bolter, K., Mitsova, D., Garces, K.P., King, R., Carballo, I.C., \& Hamilton, K. (2016). Assessing Potential Impacts of Sea-level Rise on Public Health and Vulnerable Populations in Southeast Florida and Providing a Framework to Improve Outcomes. Sustainability, 8:4, 315 doi: https://doi.org/10.3390/su8040315.

Boesch, D.F., Boicourt, W.C., Cullather, R.I., Ezer, T., Galloway Jr., G.E., Johnson, Z.P., Kilbourne, K.H., Kirwan, M.L., Kopp, R.E., Land, S., Li, M., Nardin, W. Sommerfield, C.K., \& Sweet ,W.V. (2018). Sea-level Rise: Projections for Maryland 2018, 27 pp. University of Maryland Center for Environmental Science, Cambridge, MD. https://mde.maryland.gov/programs/Air/ ClimateChange/MCCC/Documents/Sea-LevelRiseProjectionsMaryla nd2018.pdf

Boston Research Advisory Group (BRAG, 2016). Climate Change and Sea-Leve Rise Projections for Boston. Climate Ready Boston Report. https://www boston.gov/sites/default/files/document-file-12-2016/brag_report_final.pdf.

Bouttes, N., Gregory, J.M., Kuhlbrodt, T., Smith, R.S. (2014). The Drivers of Projected North Atlantic Sea Level Change. Climate Dynamics, 43:5-6, 1531-1544. https://doi.org/10.1007/s00382-013-1973-8.

Bradley, S.L., Milne, G.A., Horton, B.P., \& Zong, Y. (2016). Modelling Sea Level Data from China and Malay-Thailand to Estimate Holocene Ice-Volume Equivalent Sea Level Change. Quaternary Science Reviews, 137, 54-68. https://doi.org/10.1016/j.quascirev.2016.02.002

Brienen, R.J.W., Phillips, O.L., Feldpausch, T.R., Gloor, E., Baker, T.R., Lloyd, J. et al. (2015). Long-Term Decline of the Amazon Carbon Sink. Nature, 519 , 344-348. https://doi.org/10.1038/nature14283.
Burakowski, E., Grogan, D., Wake, C. (2019). Historical and Future Climate in the Northeastern United States, 1980-2099. American Association of Geographers Annual Meeting, Washington, DC. https://aag.secureabstracts.com/AAG\%20Annual\%20Meeting\%202019/abstractsgallery/19581.

Caesar, L., Rahmstorf, S., Robinson, A., Feulner, G, \& Saba,V. (2018). Observed Fingerprint of a Weakening Atlantic Ocean Overturning Circulation. Nature, 556, 191-196. https://doi.org/10.1038/s41586-018-0006-5.

Callahan, J.A., Horton, B.P., Nikitina, D.L., Sommerfield, C.K., McKenna, T.E., \& Swallow, D. (2017). Recommendations of Sea-Level Rise Planning Scenarios for Delaware: Technical Report, prepared for Delaware Department of Natural Resources and Environmental Control (DNREC) Delaware Coastal Programs. 115p. http://www.dgs.udel.edu/sites/ default/files/projects-docs/de\%20slr\%202017\%20technical\%20 report\%20final.pdf.

Castellano, C.M. \& DeGaetano, A.T. (2017). Downscaling Extreme Precipitation from CMIP5 Simulations Using Historical Analogs. Journal of Applied Meteorology and Climatology, 56:9, 2421-2439. doi: https://doi.org/10.1175/JAMC-D-16-0250.1.

Cazenave, A., Palanisamy, H., \& Ablain, M. (2018). Contemporary Sea Level Changes from Satellite Altimetry: What Have We Learned? What are the New Challenges? Advances in Space Research, 62, 1639-165. doi: https://doi.org/10.1016/j.asr.2018.07.017.

Chang, E., K. M., Ma, C.-G., Zheng, C. \& Yau, A.M.W. (2016). Observed and Projected Decrease in Northern Hemisphere Extratropical Cyclone Activity in Summer and its Impacts on Maximum Temperature. Geophysical Research Letters, 43, 2200-2208. https://doi.org/10.1002/2016GL068172.

Charette, M., Gonneea, M., \& Mulligan, A. (2012). Sea Level Anomalies Influence Coastal Groundwater Dynamics and Discharge, 2012 American Geophysical Union Fall Meeting (AGU 2012), San Francisco, California, Dec 3, 2012.

Chen, C., Liu, H., \& Beardsley, R. C. (2003). An Unstructured Grid Finite-Volume Three-Dimensional Primitive Equations Ocean Model: Application to Coastal Ocean and Estuaries. Journal of Atmospheric and Oceanic Technology, 20, 159-186. https://doi.org/10.1175/1520-0426(2003)020\%3C0159:AUGFVT\%3E2.0.CO;2.

Chen X., Zhang, X., Church, J.A., Watson, C.S., King, M.A., Monselesan, D., Legresy, B., \& Harig, C. (2017). The Increasing Rate of Global Mean SeaLevel Rise During 1993-2014. Nature Climate Change, 7, 492-495. doi: https://doi.org/10.1038/nclimate3325.

Christensen P, K Gillinghamb, W Nordhaus (2018) Uncertainty in forecasts of long-run economic growth. PNAS 115, 5409-5414. doi/10.1073/ pnas. 1713628115 
Church, J.A., Gregory, J.M., White, N.J., Platten, S.M. \& Mitrovica, J.X. (2011) Understanding and Projecting Sea Level Change. Oceanography, 24, 130-143. https://doi.org/10.5670/oceanog.2011.33.

Church, J.A., Clark, P.U., Cazenave, A., Gregory, J.M., Jevrejeva, S., Levermann, A., Merrifield, M.A., Milne, G.A., Nerem, R.S., Nunn, P.D., Payne, A.J., Pfeffer, W.T., Stammer, D. \& Unnikrishnan, A.S. (2013). Sea Level Change. Climate Change 2013: The Physical Science Basis. Contribution of Working Group I to the Fifth Assessment Report of the Intergovernmental Panel on Climate Change. Stocker, T.F., Qin, D., Plattner, G.-K., Tignor, M., Allen, S.K., Boschung, J., Nauels, A., Xia, Y., Bex, V. \& Midgley, P.M., Eds. Cambridge University Press, Cambridge, United Kingdom and New York, NY, USA, 1137-1216. http://www.climatechange2013.org/report/full-report/.

Cohen, J., Pfeiffer, K. \& Francis, J.A. (2018). Warm Arctic Episodes Linked with Increased Frequency of Extreme Winter Weather in the United States. Nature Communications, 9:869. doi: https://doi.org/10.1038/s41467-018-02992-9.

Colle, B.A., Zhang, Z., Lombardo, K.A., Chang, E., Liu, P. \& Zhang, M. (2013). Historical Evaluation and Future Prediction of Eastern North American and Western Atlantic Extratropical Cyclones in the CMIP5 Models During the Cool Season. Journal of Climate, 26, 6882-6903. doi: https://doi.org/10.1175/JCLI-D-12-00498.1.

Collins, M.J. (2009). Evidence for Changing Flood Risk in New England Since that late 20th Century. Journal of the American Water Resources Association, 45:2, 279-290. doi: https://doi.org/10.1111/j.1752-1688.2008.00277.x.

Collins, M.J., Kirk, J.P., Pettit, J., DeGaetano, A.T., McCown, M.S., Peterson, T.C. Means, T.N. \& Zhang, X. (2014). Annual Floods in New England (USA) and Atlantic Canada: Synoptic Climatology and Generating Mechanisms. Physical Geography, 35, 195-219. doi: https://doi.org/10.1080/02723646.2014.888510.

Complex Systems Research Center, University of New Hampshire. (CSRC-UNH, 2004). New Hampshire Surficial Geology Dataset. Available at: http://www.granit.unh.edu/data/search?dset=surf\&\#47;surf167.

Complex Systems Research Center, University of New Hampshire (CSRC-UNH, 2006). New Hampshire Hydrography Dataset. Available at: http://www.granit.unh.edu/cgi-bin/nhsearch?dset=nhhd\&\#47;nh.

Cook, S., Lippmann, T.C. \& Irish, J.D. (2019). Modeling Nonlinear Tidal Evolution in an Energetic Estuary. Ocean Modelling, 36, 13-27. doi: https://doi.org/10.1016/j.ocemod.2019.02.009.

Cooper, H., Zhang, C. \& Selch, D. (2015). Incorporating Uncertainty of Groundwater Modeling in Sea-Level Rise Assessment: A Case Study in South Florida, Climate Change, 129:1-2, 281-294. doi: http://dx.doi.org/10.1007/s10584-015-1334-1.
Cooper, J.A., Loomis, G.W. \& Amador, J.A. (2016). Hell and High Water: Diminished Septic System Performance in Coastal Regions Due to Climate Change, PLoS ONE, 11:9. doi: https://doi.org/10.1371/journal.pone.0162104.

Dalton, M.M., Dello, K.D., Hawkins, L., Mote, P.W., Rupp, D.E. (2017). The Third Oregon Climate Assessment Report, Oregon Climate Change Research Institute, College of Earth, Ocean and Atmospheric Sciences, Oregon State University, Corvallis, OR. http://www.occri.net/media/1042/ocar3_final_125_web.pdf.

Dangendorf, S., Marcos, M., Woppelmann, G., Conrad, C.P., Frederikse, T. \& Riva, R. (2017). Reassessment of 20th Century Global Mean Sea Level Rise. PNAS, 114:23, 5946-51. doi: https://doi.org/10.1073/pnas.1616007114.

DeConto, R.M. \& Pollard, D. (2016). Contribution of Antarctica to Past and Future Sea-Level Rise. Nature, 531, 591-597. doi: http://dx.doi.org/10.1038/nature17145

DeGaetano, A.T. (2009). Time-Dependent Changes in Extreme-Precipitation Return-Period Amounts in the Continental United States. Journal of Applied Meteorology and Climatology, 48, 2086-2099. doi: https://doi.org/10.1175/2009JAMC2179.1.

Demaria, E.M.C., Palmer, R.N., \& Roundy, J.K. (2016). Regional Climate Change Projections of Streamflow Characteristics in the Northeast and Midwest U.S. Journal of Hydrology: Regional Studies, 5, 309-323. doi: https://doi.org/10.1016/j.ejrh.2015.11.007.

Deschamps, P., Durand, N., Bard, E., Hamelin, B., Camoin, G., Thomas, A.L., Henderson, G.M., Okuno, J.I. \& Yokoyama, Y. (2012). Ice-Sheet Collapse and Sea-Level Rise at the Bolling Warming 14,600 Years Ago. Nature, 483, 559-564. doi: https://doi.org/10.1038/nature10902.

Douglas, E.M., Vogel, R.M., \& Kroll, C.N. (2000). Trends in Floods and Low Flows in the United States: Impact of Spatial Correlation. Journal of Hydrology, 240:1-2, 90-105. doi: https://doi.org/10.1016/S0022-1694(00)00336-X.

Douglas E.M. \& Fairbank, C.A. (2011). Is Precipitation In Northern New England Becoming More Extreme? Statistical Analysis of Extreme Rainfall In Massachusetts, New Hampshire, and Maine and Updated Estimates of the 100-Year Storm. Journal of Hydrologic Engineering, 16:3, 203-217. doi: https://doi.org/10.1061/(ASCE)HE.1943-5584.0000303.

Dripps, W.R. \& Bradbury K.R. (2007). A Simple Daily Soil-Water Balance Model for Estimating the Spatial and Temporal Distribution of Groundwater Recharge in Temperate Humid Areas, Hydrogeology Journal, 15, 433-44. doi: https://doi.org/10.1007/s10040-007-0160-6.

Dunne, T. \& Black, R.D. (1970). Partial Area Contributions to Storm Runoff in a Small New England Watershed. Water Resources Research, 6, 1296-1311. doi: https://doi.org/10.1029/WR006i005p01296. 
Dupigny-Giroux, L.A., Mecray, E.L., Lemcke-Stampone, M.D., Hodgkins, G.A., Lentz, E.E., Mills, K.E., Lane, E.D., Miller, R., Hollinger, D.Y., Solecki, W.D. Wellenius, G.A., Sheffield, P.E., MacDonald, A.B. \& Caldwell, C. (2018). Northeast. In Impacts, Risks, and Adaptation in the United States: Fourth National Climate Assessment, Volume II [Reidmiller, D.R., Avery, C.W., Easterling, D.R., Kunkel, K.E., Lewis, K.L.M., Maycock, T.K. \& Stewart, B.C. (eds.)]. U.S. Global Change Research Program, Washington, DC, USA, pp. 669-742. doi: http://dx.doi.org/10.7930/NCA4.2018.CH18.

Easterling, D.R., Kunkel, K.E., Arnold, J.R., Knutson, T., LeGrande, A.N., Leung, L.R., Vose, R.S., Waliser, D.E. \& Wehner, M.F. (2017). Precipitation Change in the United States. Climate Science Special Report: Fourth National Climate Assessment, Volume I. Wuebbles, D.J., Fahey, D.W., Hibbard,

K.A., Dokken, D.J., Stewart, B.C. \& Maycock, T.K. Eds. U.S. Global Change Research Program, Washington, DC, USA, 207-230. doi: http://dx.doi.org/10.7930/J0H993CC.

Edwards, T.L., Brandon, M.A., Durand, G., Edwards, N.R., Golledge, N.R., Holden, P.B., Nias, I.J., ..., \& Wernecke, A. (2019). Revisiting Antarctic Ice Loss Due to Marine Ice-Cliff Instabilitiy. Nature, 566, 58-64. doi: https://doi.org/10.1038/s41586-019-0901-4.

Elmir, S. (2018). Septic Systems Vulnerable to Sea-level rise. Final Report in support of Resolution No. R-911-16. Developed collaboratively by the Miami-Dade County Department of Regulatory \& Economic Resources, Miami-Dade County Water and Sewer Department \& Florida Department of Health in Miami-Dade County (Dr. Samir Elmir). https://www. miamidade.gov/green/library/vulnerability-septic-systems-sea-levelrise.pdf.

Emanuel, K. (2007). Environmental Factors Affecting Tropical Cyclone Power Dissipation, Journal of Climate, 20:22, 5497-5509, doi: https://doi.org/10.1175/2007JCLI1571.1.

Emanuel, K. (2013). Downscaling CMIP5 Climate Models Shows Increased Tropical Cyclone Activity Over the $21^{\text {st }}$ Century. PNAS., 110:30, 12219-24. doi: https://doi.org/10.1073/pnas.1301293110.

Ezer, T., Atkinson, L.P., Corlett, W.B. \& Blanco, J.L. (2013). Gulf Stream's Induced Sea Level Rise and Variability Along the Mid-Atlantic Coast. Journal of Geophysical Research: Oceans, 118:2, 685-97. doi: https://doi.org/10.1002/jgrc.20091.

Ezer, T. \& Atkinson, L.P. (2014). Accelerated Flooding Along the U.S. East Coast: On the Impact of Sea-Level Rise, Tides, Storms, the Gulf Stream, and the North Atlantic Oscillations. Earth's Future, 2, 362-382. doi: https://doi.org/10.1002/2014EF000252.

Fadhel, S., Rico-Ramirez, M.A. \& Han, D. (2017). Uncertainty of IntensityDuration Frequency (IDF) Curves Due to Varied Climate Baseline Periods. Journal of Hydrology, 547, 600-612.

doi: https://doi.org/10.1016/j.jhydrol.2017.02.013.
Favier, L., Durand, G., Cornford, S. L., Gudmundsson, G.H., Gagliardini, O., Gillet-Chaulet, F., Zwinger, T., Payne, A.J., \& Le Brocq, A.M. (2014). Retreat of Pine Island Glacier Controlled by Marine Ice-Sheet Instability. Nature Climate Change, 4, 117-121. doi: https://doi.org/10.1038/nclimate2094.

Federal Emergency Management Agency. (FEMA, 2005a). Flood Insurance Study: Strafford County, New Hampshire. FIS Number 33017CV000A. Available at: https://map1.msc.fema.gov/data/33/S/PDF/33017CV000A. pdf?LOC=9ae98fOfd3d7e3ab2b0da588228b8f14.

Federal Emergency Management Agency. (FEMA, 2005b). Flood Insurance Study, Rockingham County, New Hampshire, All Jurisdictions, Federal Emergency Management Agency, FIS Number 33015CV001A. Available at: https://map1.msc.fema.gov/data/33/S/PDF/33015CV001A. pdf?LOC=7e29d464f0a0b9609c6dbc488dce8a1a.

Federal Emergency Management Agency. (FEMA, 2008). Independent Evaluation of Recent Flooding in New Hampshire. Report prepared by URS Group. Available at: https://www.fema.gov/media-librarydata/20130726-1635-20490-0578/nh_flooding_analysis_report_7_28.pdf

Federal Emergency Management Agency. (FEMA, 2012). Multi-hazard Loss Estimation Methodology, Flood Model, HAZUS-MH, Technical Manual. Department of Homeland Security, Federal Emergency Management Agency. Available at: https://www.hsdl.org/?view\&did=701266.

Federal Emergency Management Agency. (FEMA, 2015) Flood Insurance Study: Strafford County, New Hampshire. FIS Number 33017CV000B. Available at:

http://www.granit.unh.edu/dfirms/d-FISpdfs/FIS33017CV000B.pdf.

Federal Emergency Management Agency. (FEMA, 2016). Flood Insurance Study, Rockingham County, New Hampshire, All Jurisdictions, Federal Emergency Management Agency, FIS Number 33015CV001B. Available at: https://map1.msc.fema.gov/data/33/S/PDF/33017CV000B. pdf?LOC $=58 \mathrm{e} 63 c 9 c 11$ e4c79cdae042f6daa74902.

Federal Emergency Management Agency. (FEMA, 2019). Disaster Declarations. Available at: http://www.fema.gov/disasters.

Fiore, A.R., Voronin, L.M. \& Wieben, C.M. (2018). Hydrogeology of, Simulation of Groundwater Flow in, and Potential Effects of Sea-Level Rise on the Kirkwood-Cohansey Aquifer System in the Vicinity of Edwin B. Forsythe National Wildlife Refuge, New Jersey: U.S. Geological Survey Scientific Investigations Report 2017-5135, 59 p. doi: https://doi.org/10.3133/sir20175135.

Flato, G., Marotzke, J., Abiodun, B., Braconnot, P., Chou, S.C., Collins, W., Cox, P., Driouech, F., Emori, S., Eyring, V., Forest, C., Gleckler, P., Guilyardi, E., Jakob, C., Kattsov, V., Reason, C. \& Rummukainen, M. (2013). Evaluation of Climate Models. In: Climate Change 2013: The Physical Science Basis. Contribution of Working Group I to the Fifth Assessment Report of the Intergovernmental Panel on Climate Change [Stocker, T.F., Qin, 
D., Plattner, G.-K., Tignor, M., Allen, S.K., Boschung, J., Nauels, A., Xia, Y., Bex, V., \& Midgley, P.M. (eds.)]. Cambridge University Press, Cambridge, United Kingdom and New York, NY, USA. https://www.ipcc.ch/site/assets/ uploads/2018/02/WG1AR5_Chapter09_FINAL.pdf.

Flood, J.F. \& Cahoon, L.B. (2011). Risks to Coastal Wastewater Collection Systems from Sea-Level Rise and Climate Change. Journal of Coastal Research, 27:4, 652-660, doi: http://dx.doi.org.libproxy.unh.edu/10.2112/ JCOASTRES-D-10-00129.1.

Forsberg, R., Sørensen, L., \& Simonsen, S. (2016). Greenland and Antarctica Ice Sheet Mass Changes and Effects on Global Sea Level. Surveys in Geophysics, 38, 89-104. doi: https://doi.org/10.1007/s10712-016-9398-7.

Francis, J.A., Vavrus, S.J. \& Cohen, J. (2017). Amplified Arctic Warming and MidLatitude Weather: New Perspectives on Emerging Connections. WIREs Climate Change, 8, e474. doi: https://doi.org/10.1002/wcc.474.

Frei, A., Kunkel, K.E., \& Matonse, A. (2015). The Seasonal Nature of Extreme Hydrological Events in the Northeastern United States. Journal of Hydrometeorology, 16:5,2065-2085. doi: https://doi.org/10.1175/ JHM-D-14-0237.1. Geosyntec Consutants. (2016). Analysis of Flood Damage Cost Avoidance in the Lamprey River Watershed of New Hampshire. FINAL REPORT. http://100yearfloods.org/resources/ pdf/2016_Geosyntec_LampreyHazus.pdf.

Gent, P.R., Danabasoglue, G., Donner, L.J., Holland, M.M., Hunke, E.C., Jayne, S.R., Lawrence, D.M., Neale, R.B., Rasch, P.J, Vertenstein, M., Worley, P.H., Yang, Z.-L. \& Zhang, M. (2011). The Community Climate System Model Version 4. Journal of Climate, 24, 4973-4491. doi: https://doi.org/10.1175/2011JCLI4083.1.

Graff, L. \& Middleton, J. (2001). Wetlands and Fish: Catch the Link. U.S. Dept. of Commerce, National Oceanic and Atmospheric Administration, National Marine Fisheries Service, Office of Habitat Conservation. Silver Spring, MD.

Greene, C.H., Francis, J.A., \& Monger, B.C. (2015). Superstorm Sandy: A series of Unfortunate Events? Oceanography, 26, 8-9. doi: https://doi.org/10.5670/oceanog.2013.11.

Gregory, J.M., White, N.J., Church, J.A., Bierkens, M.F.P., Box, J.E., van den Broeke, M.R., Cogley,..., \& van de Wal, R.S.W. (2013). Twentieth-Century Global-Mean Sea-Level Rise: Is the Whole Greater than the Sum of the Parts? Journal of Climate, 26, 4476-4499. doi: https://doi.org/10.1175/JCLI-D-12-00319.1.

Gregory, J.M, Griffies, S.M., Hughes, C.W., Lowe, J.A., Church, J.A., Fukimori, I., Gomez, N.,..., \& van de Wal, R.S.W. (2019). Concepts and Terminology for Sea Level: Mean, Variability and Change, Both Local and Global. Surveys in Geophysics. doi: https://doi.org/10.1007/s10712-019-09525-z.

Griggs, G., Arvai, J., Cayan, D., DeConto, R., Fox, J., Fricker, H.A., Kopp, R.E. Tebaldi, C., Whiteman, E.A. (California Ocean Protection Council Science Advisory Team Working Group). (2017). Rising Seas in California: An
Update on Sea-Level Rise Science. California Ocean Science Trust. http://www.opc.ca.gov/webmaster/ftp/pdf/docs/rising-seas-incalifornia-an-update-on-sea-level-rise-science.pdf.

Grilli, A.R., Spaulding, M.L., Oakley, B.A. \& Damon, C. (2017). Mapping the Coastal Risk for the Next Century, Including Sea-Level Rise and Changes in the Coastline: Application to Charlestown RI, USA. Natural Hazards, 88:1, 389-414. doi: https://doi.org/10.1007/s11069-017-2871-x.

Guilbert, J., Betts, A.K., Rizzo, D.M., Beckage, B. \& Bomblies, A. (2015). Characterization of Increased Persistence And Intensity of Precipitation in the Northeastern United States, Geophysical Research Letters, 42, 1888-1893. doi: https://doi.org/10.1002/2015GL063124.

Habel, S., Fletcher, C.H., Rotzoll, K. \& El-Kadi, A.I. (2017). Development of a Model to Simulate Groundwater Inundation Induced by Sea-Level Rise and High Hides in Honolulu, Hawaii, Water Research, 114, 122-134. doi: https://doi.org/10.1016/j.watres.2017.02.035.

Hall, J.A., Gill, S., Obeysekera, J., Sweet, W., Knuuti, K., \& Marburger, J. (2016). Regional Sea Level Scenarios for Coastal Risk Management: Managing the Uncertainty of Future Sea Level Change and Extreme Water Levels for Department of Defense Coastal Sites Worldwide. U.S. Department of Defense, Strategic Environmental Research and Development Program. 224 pp. https://www.serdp-estcp.org.

Harbaugh, A.W. (2005). MODFLOW-2005, The U.S. Geological Survey Modular Ground-Water Model-the Ground-Water Flow Process: U.S. Geological Survey Techniques and Methods, 6-A16. doi: https://doi.org/10.3133/tm6A16.

Hay, C.C., Morrow, E., Kopp, R.E., \& Mitrovica, J.X. (2015) Probabilistic Reanalysis of Twentieth-Century Sea-Level Rise. Nature, 517, 481-484 doi: https://doi.org/10.1038/nature14093.

Hayhoe, K., Wake, C.P., Bradbury, J., Huntington, T., Luo, L., Swartz, M.D., Sheffield, J., Anderson, B., DeGaetano, A., Wolfe, D., \& Wood, E. (2007). Past and Future Changes in Climate and Hydrological Indicators in the U.S. Northeast. Climate Dynamics, 28, 381-407. doi: https://doi.org/10.1007/s00382-006-0187-8.

Hayhoe, K., Wake, C.P., Anderson, B., Liang, X.-Z., Maurer, E., Zhu, J., Bradbury, J., DeGaetano, A., Stoner, A.M.,\& Wuebbles, D. (2008). Regional Climate Change Projections for the Northeast U.S. Mitigation and Adaptation Strategies for Global Change, 13, 425-436. doi: https://doi.org/10.1007/s11027-007-9133-2.

Hayhoe, K., Stoner, A., Abeysundara, S., Daniel, J.S., Jacobs, J.M., Kirshen, P. \& Benestad, R. (2015). Climate Projections for Transportation Infrastructure Planning, Operations and Maintenance, and Design, Transportation Research Record, 2510, 90-97. doi: https://doi.org/10.3141\%2F2510-11.

Hayhoe, K., Edmonds, J., Kopp, R.E., LeGrande, A.N., Sanderson, B.M., Wehner, 
M.F., \& Wuebbles, D.J. (2017). Climate Models, Scenarios, and Projections. In: Climate Science Special Report: Fourth National Climate Assessment, Volume I [Wuebbles, D.J., Fahey, D.W., Hibbard, K.A., Dokken, D.J., Stewart, B.C., \& May- cock, T.K. (eds.)]. U.S. Global Change Research Program, Washington, DC, USA, pp. 133-160. doi: http://dx.doi.org/10.7930/J0WH2N54.

Hedin, L.O. (2015). Biogeochemistry: Signs of saturation in the Tropical Carbon Sink. Nature, 519, 295-296. doi: https://doi.org/10.1038/519295a.

Hershfield, D.M. (1961) Rainfall Frequency Atlas of the United States, Technical Paper No. 40. Weather Bureau, US Department of Commerce, Washington, DC. https://www.nws.noaa.gov/oh/hdsc/PF_documents/ TechnicalPaper_No40.pdf.

Hodgkins, G.A. (2010). Historical Changes in Annual Peak Flows in Maine and Implications for Flood-Frequency Analyses. USGS Scientific Investigations Report 2010-5094, 38. doi: https://doi.org/10.3133/sir20105094.

Hoerling, M., Eischeid, J., Perlwitz, J., Quan, X.-W., Wolter, K. \& Cheng, L. (2016). Characterizing Recent Trends in U.S. Heavy Precipitation. Journal of Climate, 29:7, 2313-2332. doi: https://doi.org/10.1175/JCLI-D-15-0441.1.

Hoover, D.J., Odigie, K.O., Swarzenski, P.W., \& Barnard, P. (2017). Sea-level Rise and Coastal Groundwater Inundation and Shoaling at Select Sites in California, USA. Journal of Hydrology: Regional Studies, 11 (Supplement C), 234-249. doi: https://doi.org/10.1016/j.ejrh.2015.12.055.

Horton, R., Little, C., Gornitz, V., Bader, D., \& Oppenheimer, M. (2015). New York City Panel on Climate Change 2015 Report Chapter 2: Sea-Level Rise and Coastal Storms, Annals of the New York Academy of Sciences, 1336, 3644. doi: https://doi.org/10.1111/nyas.12593.

Horton, B.P., Kopp, R.E., Garner, A.J., Hay, C.C., Khan, N.S., Roy, K., \& Shaw, T.A. (2018). Mapping Sea-Level Change in Time, Space, and Probability. Annual Review of Environment and Resources, 43, 481-521. doi: https://doi.org/10.1146/annurev-environ-102017-025826.

Houser, T., Kopp, R., Hsiang, S.M., Delgado, M., Jina, A., Larsen, K., Mastrandrea, M., Mohan, S., Muir-Wood, R., Rasmussen, D.J., Rising, J., \& Wilson, P. (2014). American Climate Prospectus: Economic Risks in the United States. Retrieved from: http://www.impactlab.org/research/american-climate-prospectus/.

Huang, H., Winter, J.M., Osterberg, E.C., Horton, R.M., \& Beckage B. (2017). Total and Extreme Precipitation Changes over the Northeastern United States. Journal of Hydrometeorology, 18, 1783-1798. doi: https://doi.org/10.1175/JHM-D-16-0195.1.

Hughes, T. (1973). Is the West Antarctic Ice Sheet Disintegrating? Journal of Geophysical Research, 78:33, 7884-7910. doi: https://doi.org/10.1029/JC078i033p07884.

Intergovernmental Panel on Climate Change. (IPCC, 2007). Climate Change 2007: The Physical Science Basis. Contribution of Working Group I to the Fourth Assessment Report of the Intergovernmental Panel on Climate Change. [Solomon, S. et al. (eds)]. Cambridge University Press, Cambridge, UK. 996 p. https://www.ipcc.ch/report/ar4/wg1/.

Ivancic, T.J. \& Shaw, S.B. (2015). Examining Why Trends in Very Heavy Precipitation Should Not Be Mistaken for Trends in Very High River Discharge. Climate Change, 133, 681-693.

doi: https://doi.org/10.1007/s10584-015-1476-1.

Iverson, G., O'driscoll, M.A., Humphrey Jr, C.P., Manda, A.K., \& Andersonevans, E. (2015). Wastewater Nitrogen Contributions to Coastal Plain Watersheds, NC, USA. Water, Air and Soil Pollution, 226, 1-17. doi: https://doi.org/10.1007/s11270-015-2574-4.

Jacobs, J., Knott, J., Durfee, E., Mack, R., \& Pimental, K. (2017). Sea-Level Rise Impacts on Drinking Water - A Groundwater Modeling Study in Newmarket, NH. http://www.strafford.org/cmsAdmin/uploads/final_ groundwater-modeling-report_001.pdf.

Janssen, E., Sriver, R.L., Wuebbles, D.J. \& Kunkel, K.E. (2016). Seasonal and Regional Variations in Extreme Precipitation Event Frequency Using CMIP5. Geophysical Research Letters, 43, 5385-5393. doi: https://doi.org/10.1002/2016GL069151.

Johnson, D.W. (1994). Keynote Paper. Rising Groundwater Levels: Engineering and Environmental Implications. Groundwater Problems in Urban Areas, pp. 285-298, Thomas Telford Publishing. doi: https://doi.org/10.1680/gpiua.19744.0021.

Joughin, I., Smith, B.E., \& Medley, B. (2014). Marine Ice Sheet Collapse Potentially Under Way for the Thwaites Glacier Basin, West Antarctica. Science, 344:6185, 735-738. doi: https://doi.org/10.1126/science.1249055.

Kelley, J.T., Gehrels, W.R. \& Belknap, D.F. (1995). Late Holocene Relative SeaLevel Rise and the Geological Development of Tidal Marshes at Wells, Maine. Journal of Coastal Research, 11, 136-153. http://journals.fcla.edu/jcr/article/view/79515/0.

Kemp, A.C., Wright, A.J., Edwards, R.J., Barnett, R.L., Brain, M.J., Kopp, R.E., Cahill, N., Horton, B.P., Charman, D.J., Hawkes, A.D., Hill, T.D., \& van de Plassche, O. (2018). Relative Sea-Level Change in Newfoundland, Canada During the Past 3000 Years. Quaternary Sciences Review, 201, 89-110. doi: https://doi.org/10.1016/j.quascirev.2018.10.012.

Khan, S.A., Aschwanden, A., Bjørk, A.A., Wahr, J., Kjeldsen, K.K., Kjær, K.H. (2015). Greenland Ice Sheet Mass Balance: A Review. Reports on Progress in Physics, 78, 1-26. doi: https://doi.org/10.1088/0034-4885/78/4/046801.

Kirshen, P., Watson, C.J., Douglas, E., Gontz, A., Lee, J., \& Tian, Y. (2008), Coastal Flooding in the Northeastern United States Due to Climate Change. Mitigation and Adaptation Strategies for Global Change, 13:5-6, 437- 451. doi: https://doi.org/10.1007/s11027-007-9130-5. 
Kirshen, P., Wake, C.P., Huber, M., Knuuti, K., \& Stampone, M. (2014). Sea-level Rise, Storm Surges, and Extreme Precipitation in Coastal New Hampshire: Analysis of Past and Projected Future Trends. Science and Technical Advisory Panel Report for the NH Coastal Risk and Hazards Commission, 44 pp. http://www.nhcrhc.org/stap-report/.

Kirshen, P., Aytur, S., Burdick, D., Foster, D., \& Lippmann, T. (2018). Integrated analysis of the value of wetland services in coastal adaptation: methodology and case study of Hampton-Seabrook Estuary, New Hampshire, NOAA Final Report for Award Number NA14OAR4310194, 68 pp. https://scholars.unh.edu/jel/154.

Knott, J.F., Daniel, J.S., Jacobs, J.M., Kirshen, P., \& Elshaer, M. (2017). Assessing the Effects of Rising Groundwater from Sea-Level Rise on the Service Life of Pavements in Coastal Road Infrastructure. TRB Research Record: Journal of Transportation Research Board, 2639, 1-10. doi: https://doi.org/10.3141\%2F2639-01.

Knott, J.F., Jacobs, J., Daniel, J.S., \& Kirshen, P. (2018a). Modeling Groundwater Rise Caused by Sea-Level Rise in Coastal New Hampshire. Journal of Coastal Research, 35, 143-157.

doi: https://doi.org/10.2112/JCOASTRES-D-17-00153.1.

Knott, J.F., Daniel, J.S., Jacobs, J.M., \& Kirshen, P. (2018b). Adaptation Planning to Mitigate Coastal-Road Pavement Damage from Groundwater Rise Caused by Sea-Level Rise. TRB Research Record: Journal of Transportation Research Board, 2672:2, 11-22. doi: https://doi.org/10.1177\%2F0361198118757441.

Knutson, T.R., Sirutis, J.J., Vecchi, G.A., Garner, S., Zhao, M., \& Kim, H.-S. (2013). Dynamical Downscaling Projections of Twenty-First-Century Atlantic Hurricane Activity: CMIP3 and CMIP5 Model-Based Scenarios, Journal of Climate, 26:17, 6591-6617. doi: https://doi.org/10.1175/ JCLI-D-12-00539.1.

Komurcu, M., Emanuel, K.A., Huber, M., \& Acosta, R.P. (2018). High-Resolution Climate Projections for the Northeastern United States Using Dynamical Down- Scaling at Convection-Permitting Scales. Earth and Space Science, 5, 801-826. doi: https://doi.org/10.1029/2018EA000426.

Kopp, R.E. (2013). Does the Mid-Atlantic United States Sea Level Acceleration Hot Spot Reflect Ocean Dynamic Variability? Geophysical Research Letters, 40, 3981-3985. doi: https://doi.org/10.1002/grl.50781.

Kopp, R.E., Horton, R.M., Little, C.M., Mitrovica, J.X., Oppenheimer, M., Rasmussen, D.J., Strauss, B.H., \& Tebaldi, C. (2014). Probabilistic $21^{\text {st }}$ and $22^{\text {nd }}$ Century Sea-Level Projections at a Global Network of Tide Gauge Sites. Earth's Future, 2, 287-306. doi: https://doi.org/10.1002/2014EF000239.

Kopp, R.E., Hay, C.C., Little, C.M.,\& Mitrovica, J.X. (2015). Geographic Variability of Sea-Level Change. Current Climate Change Reports, 1, 192-204. doi: https://doi.org/doi:10.7282/T37W6F4P.
Kopp, R.E., Kemp, A.C., Bittermann, K., Horton, B.P., Donnelly, J.P., Gehrels, W.R., Hay, C.C., Mitrovicak, J.X., Morrow, E.D., \& Rahmstorf S. (2016a). Temperature-Driven Global Sea-Level Variability in the Common Era. PNAS, 113:38, E5694-E5696. doi: https://doi.org/10.1073/pnas.1517056113.

Kopp, R.E., Broccoli, A., Horton, B., Kreeger, D., Leichenko, R., Miller, J.A., Orton, P., Parris, A., Robinson, D., Weaver, C.P., Campo, M., Kaplan, M., Buchanan, M., Herb, J., Auermuller, L., Andrews, C. (2016b). Assessing New Jersey's Exposure to Sea-Level Rise and Coastal Storms: Report of the New Jersey Climate Adaptation Alliance Science and Technical Advisory Panel. Prepared for the New Jersey Climate Adaptation Alliance. New Brunswick, New Jersey. https://njadapt.rutgers.edu/docman-lister/ conference-materials/167-njcaa-stap-final-october-2016/file.

Kopp, R.E., DeConto, R.M., Bader, D.A., Horton, R.M., Hay, C.C., Kulp, S. Oppenheimer, M., Pollard, D., \& Strauss, B.H. (2017a). Implications of Antarctic Ice-Cliff Collapse and Ice-Shelf Hydrofracturing Mechanisms for Sea-Level Projections. arXiv:1704.05597v2 [physics.ao-ph]. https://arxiv.org/pdf/1704.05597.pdf.

Kossin, J.P., Hall, T., Knutson, T., Kunkel, K.E., Trapp, R.J., Waliser, D.E., \& Wehner, M.F. (2017). Extreme storms. In: Climate Science Special Report: Fourth National Climate Assessment, Volume I [Wuebbles, D.J., Fahey, D.W. Hibbard, K.A., Dokken, D.J., Stewart, B.C., \& Maycock, T.K. (eds.)]. U.S. Global Change Research Program, Washington, DC, USA, pp. 257-276. doi: http://doi.org/10.7930/J07S7KXX.

Kunkel, K.E., Easterling, D.R., Kristovich, D.A.R., Gleason, B., Stoecker, L., \& Smith, R. (2010). Recent Increases in U.S. Heavy Precipitation Associated With Tropical Cyclones. Geophysical Research Letters, 37:24, L24706. doi: https://doi.org/10.1029/2010GL045164.

Kunkel, K.E., Easterling, D.R., Kristovich, D.A.R., Gleason, B., Stoecker, L., \& Smith, R. (2012). Meteorological Causes of the Secular Variations in Observed Extreme Precipitation Events for the Conterminous United States. Journal of Hydrometeorology, 13, 1131-1141. doi: https://doi.org/10.1175/JHM-D-11-0108.1.

Kunkel, K.E., Stevens, L.E., Stevens, S.E., Sun, L., Janssen, E., Wuebbles, D. Rennells, J., DeGaetano, A., \& Dobson, J.G. (2013). Regional Climate Trends and Scenarios for the U.S. National Climate Assessment: Part 1-Climate of the Northeast U.S. NOAA Tech. Rep. NESDIS 142-1, 80 pp. https://www.nesdis.noaa.gov/sites/default/files/asset/document/NOAA NESDIS_Tech_Report_142-1-Climate_of_the_Northeast_US.pdf.

Lambeck, K., Rouby, H., Purcell, A., Sun, Y. \& Sambridge, M. (2014). Sea Level and Global Ice Volumes from the Last Glacial Maximum to the Holocene. Proceedings of the National Academy of Sciences of the United States of America, 111, 15296-15303. doi: https://doi.org/10.1073/pnas.1411762111. 
Leuliette, E.W. \& Nerem, R.S. (2016). Contributions of Greenland and Antarctica to Global and Regional Sea Level Change. Oceanography, 29, 154-159. doi: https://doi.org/10.5670/oceanog.2016.107. Figures publicly available under Creative Commons Attribution 4.0 International License: https://creativecommons.org/licenses/by/4.0/.

Le Quéré, C., Andrew, R.M., Friedlingstein, P., Sitch, S., Hauck, J., Pongratz, J., Pickers, P.A., ... Zheng, B. (2018). Global Carbon Budget 2018. Earth System Science Data, 10, 2141-2194. doi: https://doi.org/10.5194/essd-10-2141-2018.

Linhoss, A.C., Kiker, G., Shirley, M., \& Frank, K. (2015). Sea-Level Rise, Inundation, and Marsh Migration: Simulating Impacts on Developed Lands and Environmental Systems. Journal of Coastal Research, 31, 36-46. doi: https://doi.org/10.2112/JCOASTRES-D-13-00215.1.

Lins, H.F., \& Slack, J.R. (2005). Seasonal and Regional Characteristics of U.S. Streamflow Trends in the United States from 1940 to 1999. Physical Geography, 26, 489-501. doi: https://doi.org/10.2747/0272-3646.26.6.489.

Lippmann, T.C., Simpson, A.E., Cook, S.E., \& Kirshen, P. (2019). Effects of Sea-Level Rise on Modeled Storm Surge and Current Speeds in New Hampshire Estuaries. Journal of Waterway, Port, Coastal, and Ocean Engineering, sub judice.

Little, C.M., Piecuch, C.G., Ponte, R.M. (2017). On the Relationship Between the Meridional Overturning Circulation, Alongshore Wind Stress, and United States East Coast Sea Level in the Community Earth System Model Large Ensemble. Journal of Geophysical Research: Oceans, 122:6, 4554-68. doi: https://doi.org/10.1002/2017JC012713.

Liu, J., Milne, G.A., Kopp, R.E., Clark, P.U., \& Shennan, I. (2016). Sea-Level Constraints on the Amplitude And Source Distribution of Meltwater Pulse 1A. Nature Geoscience, 9, 130-134. doi: https://doi.org/10.1038/ngeo2616.

Loaiciga, H.A. \& Pingel, T. (2007). $21^{\text {st }-C e n t u r y ~ S e a-l e v e l ~ r i s e, ~ E c o n o m i c ~ G r o w t h, ~}$ and Seawater Intrusion in Coastal Aquifers of California. American Geophysical Union Fall Meeting Abstracts.

Lorah, M.M. \& Olsen, L.D. (1999). Natural Attenuation of Chlorinated Volatile Organic Compounds in a Freshwater Tidal Wetland: Field Evidence of Anaerobic Biodegradation. Water Resources Research, 35, 3811-3827. doi: https://doi.org/10.1029/1999WR900116.

Luettich, R.A., Jr., Westerink, J.J., \& Scheffner, N.W. (1992). ADCIRC: An Advanced Three-Dimensional Circulation Model for Shelves, Coasts, and Estuaries; Report 1, Theory and Methodology of ADCIRC-2DDI and ADCIRC-3DL. U.S. Army Corps of Engineers Dredging Research Program Technical Report DRP-92-6. 138 pp. Available at: https://adcirc.org/files/2018/11/1992_Luettich02.pdf.
Lynch, C., Seth A., \& Thibeault, J. (2016). Recent and Projected Annual Cycles of Temperature and Precipitation in the Northeast United States from CMIP5. Journal of Climate, 29, 347-365, doi: https://doi.org/10.1175/JCLI-D-14-00781.1.

Lyons, J.B., Bothner, W.A., Moench, R.H., \& Thompson Jr, J.B. (1998). A New Bedrock Geologic Map of New Hampshire, revised.

MacDougall, A.H., Avis, C.A., \& Weaver, A.J. (2012). Significant Contribution to Climate Warming from the Permafrost Carbon Feedback. Nature Geoscience, 5:10, 719-721. doi: https://doi.org/10.1038/ngeo1573.

Mack, T.J. (2004). Assessing the Potential for Saltwater Intrusion in a Coastal Fractured-Bedrock Aquifer Using Numerical Modeling, Fractured-Rock Conference, U.S. Environmental Protection Agency/National Ground Water Association, Portland, ME, September 13-15, 2004, Proceedings, Denver, CO, National Groundwater Association, p. 220-221.

Mack, T.J. (2009). Assessment of Ground-Water Resources in the Seacoast Region of New Hampshire: U.S. Geological Survey Scientific Investigations Report, 2008-5222, 188 p. Available at https://pubs.usgs.gov/sir/2008/5222/.

Manda, A.K., Sisco, M.S., Mallinson, D.J., \& Griffin, M.T. (2015). Relative Role and Extent of Marine and Groundwater Inundation on a Dune-Dominated Barrier Island Under Sea-Level Rise Scenarios. Hydrological Processes, 29, 1894-1904. doi: https://doi.org/10.1002/hyp.10303.

Marini, G., Zollo, R., Fontana, N., Giugni, M., Singh, V. (2016). Variability and Trends in Streamflow in Northeast United States. Procedia Earth and Planetary Science, 16, 156-165. doi: https://doi.org/10.1016/j.proeps.2016.10.017

Maryland Department of Environment. (MDE, 2009). Maryland Stormwater Design Manual, Volumes 1 and II (Revised). Available at: https://mde. maryland.gov/programs/water/StormwaterManagementProgram/Pages/ stormwater_design.aspx.

Massachusetts Department of Environmental Protection. (MassDEP, 2017). Guidelines for Performing Infiltration/Inflow Analyses and Sewer System Evaluation Surveys. Available at: https://www.mass.gov/files/documents/2017/05/bad/iiguidelines517.pdf.

Masterson, J.P. (2004). Simulated Interaction Between Freshwater and Saltwater and Effects of Ground-Water Pumping and Sea-Level Change, Lower Cape Cod Aquifer System, Massachusetts: U.S. Geological Survey Scientific Investigations Report, 2004-5014, 72p. doi: https://doi.org/10.3133/sir20045014.

Masterson, J.P. \& Garabedian, S.P. (2007). Effects of Sea-Level Rise on Ground Water Flow in a Coastal Aquifer System, Ground Water, 45:2, 209-217. doi: https://doi.org/10.1111/j.1745-6584.2006.00279.x. 
Masterson, J.P., Fienen, M.N., Thieler, E.R., Gesch, D.B., Gutierrez, B.T., \& Plant, N.G. (2014). Effects of Sea-Level Rise on Barrier Island Groundwater System Dynamics: Ecohydrological Implications. Ecohydrology, 7:3, 10641071. doi: https://doi.org/10.1002/eco.1442.

McCabe, G.J., \& Wolock, D.M. (2002). A Step Increase in Streamflow in the Conterminous United States. Geophysical Research Letters, 29:24, 38-138-4. doi: https://doi.org/10.1029/2002GL015999.

McCobb, T.D. \& Weiskel, P.K. (2003). Long-term Hydrologic Monitoring Protocol for Coastal Ecosystems: U.S. Geological Survey Open File Report 02-497, 94p. doi: https://doi.org/10.3133/ofr02497.

McCuen, R. (1983). Changes in Runoff Curve Number Method. Maryland Department of Environment.

McDonnell, J.J. (2013). Are All Runoff Processes the Same? Hydrological Processes 27, 4103-4111. doi: https://doi.org/10.1002/hyp.10076.

McMillan, M., Leeson, A., Shepherd, A., Briggs, K., Armitage, T.W.K., Hogg, A., Munneke, P.K., ..., \& Gilbert, L. (2016). A High-Resolution Record of Greenland Mass Balance. Geophysical Research Letters, 43:13, 7002-7010. doi: https://doi.org/10.1002/2016GL069666.

Merrill, S.B. \& Gray, A. (2018). Preparing Portsmouth's Historic District for SeaLevel Rise. Available at: http://files.cityofportsmouth.com/files/planning/ Preparing_Portsmouths_HD_SLR_FINAL.pdf.

Mihaly, E. (2018). Avoiding Septic Shock: How Climate Change Can Cause Septic System Failure and Whether New England States are Prepared, Ocean \& Coastal Law Journal, 23. https://digitalcommons.mainelaw. maine.edu/oclj/vol23/iss1/2.

Miller, K.G., Kopp, R.E., Horton, B.P., Browning, J.V., \& Kemp, A.C. (2013). A Geological Perspective on Sea-Level Rise and Impacts Along the U.S. MidAtlantic Coast. Earth's Future, 1, 3-18. doi: https://doi.org/10.1002/2013EF000135.

Miller, I.M., Morgan, H., Mauger, G., Newton, T., Weldon, R., Schmidt, D., Welch, M., Grossman, E. (2018). Projected Sea Level Rise for Washington State - A 2018 Assessment. A collaboration of Washington Sea Grant, University of Washington Climate Impacts Group, Oregon State University, University of Washington, and US Geological Survey. Prepared for the Washington Coastal Resilience Project. https://cig.uw.edu/wp-content/uploads/ sites/2/2018/07/SLR-Report-Miller-et-al-2018.pdf.

Milne, G.A., Gehrels, W.R., Hughes, C.W., \& Tamisiea, M.E. (2009). Identifying the Causes of Sea-Level Change. Nature Geoscience, 2, 471-478. doi: https://doi.org/10.1038/ngeo544.

Mitrovica, J.X., Gomez, N., \& Clark, P.U. (2009). The Sea-Level Fingerprint of West Antarctic Collapse. Science, 323:5915, 753 pp. doi: https://doi.org/10.1126/science.1166510.
Mitrovica, J.X., Gomez, N., Morrow, E., Hay, C., Latychev, K., \& Tamisiea, M.E. (2011). On the Robustness of Predictions of Sea Level Fingerprints. Geophysical Journal International, 187:2, 729-742. doi: https://doi.org/10.1111/j.1365-246X.2011.05090.x.

Moffett, K.B., Gorelick, S.M., McLaren, R.G. \& Sudicky, E.A. (2012). Salt Marsh Ecohydrological Zonation due to Heterogeneous VegetationGroundwater-Surface Water Interactions. Water Resources Research, 48:2. doi: https://doi.org/10.1029/2011WR010874.

Moon, T., Ahlstrøm, A., Goelzer, H., Lipscomb, W., \& Nowicki, S. (2018). Rising Oceans Guaranteed: Arctic Land Ice Loss and Sea-Level Rise. Current Climate Change Reports, 4:3, 211-222. doi: https://doi.org/10.1007/s40641-018-0107-0.

Moore, R.B. (1990). Geohydrology and Water Quality of Stratified-Drift Aquifers in the Exeter, Lamprey, and Oyster River Basins, Southeastern New Hampshire: U.S. Geological Survey Water-Resources Investigations Report 88-4128, 61 p. doi: https://doi.org/10.3133/wri884128.

Morlighem, M., Williams, C.N., Rignot, E., An, L., Arndt, J.E., Bamber, J.L., Catania, G., ... \& Zinglersen, K.B. (2017). Bedmachine V3: Complete Bed Topography and Ocean Bathymetry Mapping of Greenland from Multibeam Echo Sounding Combined with Mass Conservation. Geophysical Research Letters, 44:21, 11051-11061. doi: https://doi.org/10.1002/2017GL074954.

Moss, R.H., Edmonds, J.A., Hibbard, K.A., Manning, M.R., Rose, S., van Vuuren, D.P., Carter, T.R., ..., \& Wilbanks, T.J. (2010). The Next Generation of Scenarios for Climate Change Research and Assessment. Nature, 463 747-756. doi: https://doi.org/10.1038/nature08823.

Mulligan, A.E. \& Charette, M. (2006). Intercomparison of Submarine Groundwater Discharge Estimates from a Sandy Unconfined Aquifer. Journal of Hydrology, 327:3-4, 411-425. doi: https://doi.org/10.1016/j.jhydrol.2005.11.056.

Nakicenovic, N., Alcamo, J., Davis, G., de Vries, B., Fenhann, J., Gaffin, S., Gregory, K., ..., \& Dadi, Z. (2000). Intergovernmental Panel on Climate Change Special Report on Emissions Scenarios. Available at: https:// www.ipcc.ch/site/assets/uploads/2018/03/emissions_scenarios-1.pdf.

National Oceanic and Atmospheric Administration (NOAA, 2016 \& 2019). Tides and Currents. Available at: https://tidesandcurrents.noaa.gov.

Nerem, R.S., Beckley, B.D., Fasullo, J.T., Hamilton, D., Masters, D., \& Mitchum, G.T. (2018). Climate-Change-Driven Accelerated Sea-Level Rise Detected in the Altimeter Era. Proceedings of the National Academy of Sciences, 115, 2022-2025. doi: https://doi.org/10.1073/pnas.1717312115.

NH Coastal Adaptation Workgroup (NHCAW, 2019). King Tide photos 2014 through 2018. https://www.nhcaw.org/what/king-tide-contests/. 
NH Department of Environmental Services (NHDES, 2016). New Hampshire Well Inventory. Available at: http://www4.des.state.nh.us/DESOnestop/BasicSearch.aspx.

NH Department of Transportation (NHDOT, 2010). 2010-2011 1-ft Color Aerial Photos. Available at: ftp://ftp.granit.sr.unh.edu/pub/GRANIT_ Data/2010AerialPhotography_TownZipFiles.

NH Fish and Game Department (NHFG, 2014). Sea Level Affecting Marshes Model (SLAMM) for New Hampshire. Available at: http://www.granit.unh. edu/data/metadata?file=slamm2014\%2Fnh\%2Fslamm2014.html.

New York City Economic Development Corporation (NYCDEC, 2019). Lower Manhattan Climate Resiliency Study. Available at: https://www.nycedc. com/project/lower-manhattan-coastal-resiliency.

Ocean Protection Council (OPC, 2018). State of California Sea-Level Rise Guidance - 2018 Update http://www.opc.ca.gov/webmaster/ftp/pdf/ agenda_items/20180314/Item3_Exhibit-A_OPC_SLR_Guidance-rd3.pdf

Oude Essink, G.H.P., van Baaren, E.S., \& de Louw, P.G.B. (2010). Effects of Climate Change on Coastal Groundwater Systems: A Modeling Study in the Netherlands, Water Resources Research, 46: 10. doi: https://doi. org/10.1029/2009WR008719.

Parris, A., Bromirski, P., Burkett, V., Cayan, D., Culver, M., Hall, J., Horton, R., ... \& Weiss, J. (2012). Global Sea-level Rise Scenarios for the US National Climate Assessment. NOAA Tech Memo OAR CPO-1, 37 pp. Available at: https:// scenarios.globalchange.gov/sites/default/files/NOAA_SLR_r3_0.pdf.

Paulson, R., Chase, E., Roberts, R., \& Moody, D. (1991). National Water Summary 1988-89: Hydrologic Events and Floods and Droughts: U.S. Geological Survey Water Supply Paper 2375, 591 p. doi: https://doi. org/10.3133/wsp2375.

Peltier, W.R. (1998). Postglacial Variations in the Level of the Sea: Implications for Climate Dynamics and Solid-Earth Geophysics. Reviews of Geophysics, 36:4, 603-689. doi: https://doi.org/10.1029/98RG02638.

Peltier, W.R., Argus, D.F., \& Drummond, R. (2015). Space Geodesy Constrains Ice Age Terminal Deglaciation: The Global ICE-6G_C (VM5a) Model. Journal of Geophysical Research: Solid Earth, 120:1, 450-487. doi: https:// doi.org/10.1002/2014JB011176.

Petersen, S., Bell, J., Miller, I., Jayne, C., Dean, K., \& Fougerat, M. (2015). Climate Change Preparedness Plan for the North Olympic Peninsula. A Project of the North Olympic Peninsula Resource Conservation \& Development Council and the Washington Department of Commerce, Funded by the Environmental Protection Agency. Available at: https://www.noprcd.org/ climate-change-report.

Photo Science, Inc. (2011). Coastal New Hampshire Lidar - 2011. Available at: http://lidar.unh.edu/.
Piecuch ,C.G., Huybers, P., Hay, C.C., Kemp, A.C., Little, C.M., Mitrovica, J.X., Ponte, R.M., \& Tingley, M.P. (2018). Origin of Spatial Variation in US East Coast Sea-Level Trends During 1900-2017. Nature, 564, 400 - 404. https://doi.org/10.1038/s41586-018-0787-6.

Pielke, Jr., R.A., Downton, M.W., \& Barnard Miller, J.Z. (2002). Flood Damage in the United States, 1926-2000: A Reanalysis of National Weather Service Estimates. Boulder, CO: UCAR. Available at: https://sciencepolicy. colorado.edu/flooddamagedata/flooddamagedata.pdf.

Pielke, Jr., R.A., Gratz, J., Landsea, C.W., Collins, D., Saunders, M.A., \& Musulin, R. (2008). Normalized Hurricane Damage in the United States: 19002005, Natural Hazards Review, 9:1, 29-42. https://ascelibrary.org/doi/ abs/10.1061/(ASCE)1527-6988(2008)9:1(29).

Piscataqua Region Estuaries Partnership (PREP, 2014). 2013 1-ft Resolution Imagery for Coastal New Hampshire. http://www.granit.unh.edu/data/ search?dset=2013prep\&\#47;01_A.

Pitz, C. (2016). Predicted Impacts of Climate Change on Groundwater Resources of Washington State. State of Washington Department of Ecology Publication No. 16-03-006. Available at: https://fortress.wa.gov/ ecy/publications/documents/1603006.pdf.

Popkin, G. (2015). The Hunt for the World's Missing Carbon. Nature, 523, 20-22. doi: https://doi.org/10.1038/523020a.

Rahmstorf, S., Box, J.E., Feulner, G., Mann, M.E., Robinson, A., Rutherford, S., \& Schaffernicht, E.K. (2015). Exceptional Twentieth-Century Slowdown in Atlantic Ocean Overturning Circulation. Nature Climate Change, 5, 475480. doi: https://doi.org/10.1038/nclimate2554.

Rhein, M., Rintoul, S.R., Aoki, S., Campos, E., Chambers, D., Feely, R.A., Gulev, S., .. \& Wang, F. (2013). Observations: Ocean. In: Climate Change 2013: The Physical Science Basis. Contribution of Working Group I to the Fifth Assessment Report of the Intergovernmental Panel on Climate Change [Stocker, T.F., Qin, D., Plattner, G.-K., Tignor, M., Allen, S.K., Boschung, J., Nauels, A., Xia, Y., Bex V., \& Midgley, P.M. (eds.)]. Cambridge University Press, Cambridge, UK and New York, NY, USA. Available at: https://www. ipcc.ch/site/assets/uploads/2018/02/WG1AR5_Chapter03_FINAL.pdf.

Rheinhardt, R.D. \& Fraser, K. (2001). Relationship Between Hydrology and Zonation of Freshwater Swale Wetlands on Lower Hatteras Island, North Carolina, USA. Wetlands, 21:2, 265-273. doi: https://doi.org/10.1672/02775212(2001)021[0265:RBHAZO]2.0.CO;2.

Rignot, E. (2019). Sea-Level Rise and What We Should Do About It. The National Academy of Sciences, Space Science Week Public Lecture, March 27, 2019. http://sites.nationalacademies.org/SSB/SSB_191179. 
Rignot, E., Mouginot, J., Morlighem, M., Seroussi, H., \& Scheuchl, B. (2014). Widespread, Rapid Grounding Line Retreat of Pine Island, Thwaites, Smith, And Kohler Glaciers, West Antarctica, from 1992 to 2011. Geophysical Research Letters, 41:10, 3502-3509. doi: https://doi.org/10.1002/2014GL060140.

Rignot, E., Mouginot, J., Scheuchl, B., van den Broeke, M., van Wessem, M.J., \& Morlighem, M. (2019). Four Decades of Antarctic Ice Sheet Mass Balance from 1979-2017. Proceedings of the National Academy of Sciences, 116:4, 1095-1103. doi: https://doi.org/10.1073/pnas.1812883116.

Ritchie, J. \& Dowlatabadi, H. (2017). The 1000 Gtc Coal Question: Are Cases of Vastly Expanded Future Coal Combustion Still Plausible? Energy Economics, 65:1, 16-31. doi: http://dx.doi.org/10.1016/j.eneco.2017.04.015.

Ritchie, J. \& Dowlatabadi, H. (2018). Defining Climate Change Scenario Characteristics with a Phase Space of Cumulative Primary Energy and Carbon Intensity. Environmental Research Letters, 13:2, 024012, https://doi.org/10.1088/1748-9326/aaa494.

Roshani, A. (2014). Road Infrastructure Vulnerability to Groundwater Table Variation Due to Sea-level Rise.Master of Applied Science Thesis, Queensland University of Technology, Australia. Available at: https://eprints.qut.edu.au/74509/1/Atena_Roshani_Thesis.pdf.

Rotzoll, K. \& Fletcher, C.H. (2013). Assessment of Groundwater Inundation as a Consequence of Sea-Level Rise, Nature Climate Change, 3:5, 477-481. doi: http://dx.doi.org/10.1038/nclimate1725.

Rumbaugh, J. \& Rumbaugh, D. (2011), Guide to Using Groundwater Vistas. Environmental Simulations, Inc. http://www.groundwatermodels.com/.

Runkle, J., Kunkel, K., Easterling, D., Frankson, R. \& Stewart, B. (2017). New Hampshire State Climate Summary. NOAA Technical Report NESDIS 149$\mathrm{NH}, 4$ pp. https://statesummaries.ncics.org/chapter/nh/.

Samaniego, F.J. (2010). A Comparison of the Bayesian and Frequentist Approaches to Estimation. New York, NY: Springer-Verlag. doi: https://www.doi.org/10.1007/978-1-4419-5941-6.

Sanderson, B.M., Wehner, M., \& Knutti, R. (2017). Skill and Independence Weighting for Multi-Model Assessment. Geoscientific Model Development, 10, 2379-2395. doi: https://doi.org/10.5194/gmd-10-2379-2017.

Scholz, A. (2011). Consequences of Changing Climate and Land Use to 100Year Flooding in The Lamprey River Watershed of New Hampshire. M. Sc. (Civil Engineering) Thesis, UNH. Available at: https://scholars.unh.edu/thesis/693/.

Schuur, E.A.G., McGuire, A.D., Schädel, C., Grosse, G., Harden, J.W., Hayes, D.J., Hugelius, G., ... \& Vonk, J.E. (2015). Climate Change and the Permafrost Carbon Feedback. Nature, 520, 171-179. doi: https://doi.org/10.1038/nature14338.
Shakun, J.D., Corbett, L.B., Bierman, P.R., Underwood, K., Rizzo, D.M., Zimmerman, S.R., Caffee, M.W., Naish, T., Golledge, N.R., \& Hay, C.C. (2018) Minimal East Antarctic Ice Sheet Retreat onto Land During the Past Eight Million Years. Nature, 558, $284-287$. doi: https://doi.org/10.1038/s41586-018-0155-6.

Shaw, A., Hashemi, M.R., Spaulding, M., Oakley, B., \& Baxter, C. (2016). Effect of Coastal Erosion on Storm Surge: A Case Study in the Southern Coast of Rhode Island. Journal of Marine Science and Engineering, 4:4, 85. doi: https://doi.org/10.3390/jmse4040085.

Slater, L.J., \& Villarini, G. (2016). Recent Trends in U.S. Flood Risk. Geophysical Research Letters, 43:24, 12428-12436. doi: https://doi.org/10.1002/2016GL071199.

Small, D., Islam, S., \& Vogel, R.M. (2006). Trends in Precipitation and Streamflow in the Eastern U.S.: Paradox or Perception? Geophysical Research Letters, 33, 2-5. doi: https://doi.org/10.1029/2005GL024995.

Smith, J.M., Sherlock, A.R., \& Resio, D.T. (2001). STWAVE: Steady-State Spectral Wave Model User's Manual for STWAVE, Version 3.0., U.S. Army Corps of Engineers, Coastal and Hydraulics Laboratory, ERDC/CHL Report SR-01-1, 81 pp. Available at: https://apps.dtic.mil/dtic/tr/fulltext/u2/a388197.pdf.

Spanger-Siegfried, E., Dahl, K., Caldas, A., Udvardy, S., Cleetus, R., Worth, P., Hernandez Hammer, N. (2017). When Rising Seas Hit Home: Hard Choices Ahead for Hundreds of US Coastal Communities. Union of Concerned Scientists Report. Available at: https://www.ucsusa.org/RisingSeasHitHome.

Spaulding, M.L., Grilli, A.R., Damon, C., Crean, T., Fugate, G., Oakley, B.A. \& Stempel, P. (2016). STORMTOOLS: Coastal Environmental Risk Index (CERI). Journal of Marine Science and Engineering, 4:3, 54 pp. doi: https://doi.org/10.3390/jmse4030054.

Stammer, D., Cazenave, A., Ponte, R.M., \& Tamisiea, M.E. (2013). Causes for Contemporary Regional Sea Level Changes. Annual Review of Marine Science, 5:1, 21-46. doi: https://doi.org/10.1146/annurev-marine-121211-172406.

Stein, S.M., McRoberts, R.E., Mahal, L.G., Carr, M.A., Alig, R.J., Comas, S.J., Theobald, D.M., \& Cundiff, A. (2009). Private Forests, Public Benefits: Increased Housing Density and Other Pressures on Private Forests Contributions. General Technical Report PNW-GTR-795, U.S. Department of Agriculture, Forest Service, Pacific Northwest Research Station. Available at: https://www.fs.fed.us/openspace/fote/benefits_files/pnwgtr795_pt1.pdf.

Stekl, P.J. \& Flanagan, S.M. (1992). Geohydrology and Water Quality of Stratified-Drift Aquifers in the Lower Merrimack and Coastal River Basins, Southeastern New Hampshire: U.S. Geological Survey Water-Resources Investigations Report 91-4025, 75 pp. Available at: https://pubs.usgs.gov/wri/wrir_91-4025/pdf/wrir_91-4025.pdf. 
Strawbery Banke Museum. (2017). Working to Keep History Above Water. Video by David J. Murray. http://www.strawberybanke.org/sea-level-rise.cfm.

Sweet, W.V., Horton, R., Kopp, R.E., LeGrande, A.N., \& Romanou, A. (2017a). Sea-Level Rise. In: Climate Science Special Report: Fourth National Climate Assessment, Volume I [Wuebbles, D.J., Fahey, D.W., Hibbard, K.A., Dokken, D.J., Stewart, B.C., \& Maycock, T.K. (eds.)]. U.S. Global Change Research Program, Washington,DC, USA, pp. 333-363. doi: http://doi.org/10.7930/J0VM49F2.

Sweet, W.V., Kopp, R.E., Weaver, C., Obeysekera, J., Horton, R.M., Thieler, E.R., \& Zervas, C. (2017b). Global and Regional Sea-Level Rise Scenarios for the United States. NOAA Technical Report NOS CO-OPS 083. Available at: https://tidesandcurrents.noaa.gov/publications/techrpt83_Global_ and_Regional_SLR_Scenarios_for_the_US_final.pdf. Data for the report and used in Table 4.3 can be found at: https://tidesandcurrents.noaa.gov/ publications/techrpt083.csv

Sweet, W.V., Dusek, G., Obeysekera, J., \& Marra, J.J. (2018). Patterns and Projections of High Tide Flooding Along the US Coastline Using a Common Impact Threshold. NOAA Technical Report NOS CO-OPS 086. National Oceanic and Atmospheric Administration, Silver Spring, MD. Available at: https://tidesandcurrents.noaa.gov/publications/techrpt86_ PaP_of_HTFlooding.pdf.

Swift, M.R. \& Brown, W.S. (1983). Distribution of Bottom Stress and Tidal Energy Dissipation in a Well Mixed Estuary. Estuarine and Coastal Shelf Science, 17, 297-317. doi: https://doi.org/10.1016/0272-7714(83)90024-0.

Talke, S.A., Kemp, A.C., \& Woodruff, J. (2018). Relative Sea Level, Tides, and Extreme Water Levels in Boston Harbor From 1825 to 2018. Journal of Geophysical Research: Oceans, 123. doi: https://doi.org/10.1029/2017JC013645.

Thibeault, J.M. \& Seth, A. (2014). Changing Climate Extremes in the Northeast United States: Observations and Projections from CMIP5. Climatic Change, 127, 273-287. doi: https://doi.org/10.1007/s10584-014-1257-2.

Thomas, R.H., Sanderson, T.J.O., \& Rose, K.E. (1979). Effect of Climatic Warming on the West Antarctic Ice Sheet. Nature, 277:5695, 355-358. doi: https://doi.org/10.1038/277355a0.

Thornalley, D.J.R., Oppo, D.W., Ortega, P., Robson, J.I., Brierley, C.M., Davis, R., Hall, I.R.,..., \& Keigwin, L.D. (2018). Anomalously Weak Labrador Sea Convection and Atlantic Overturning During the Past 150 Years. Nature, 556, 227-230. doi: https://doi.org/10.1038/s41586-018-0007-4.

Torbick, N. \& Corbierea, M. (2015). Mapping Urban Sprawl and Impervious Surfaces in the Northeast United States for the Past Four Decades. GIScience \& Remote Sensing, 52:6, 746-764. doi: https://doi.org/10.1080/15481603.2015.1076561.

Torio, D.D. \& Chmura, G.L. (2013). Assessing Coastal Squeeze of Tidal Wetlands, Journal of Coastal Research, 29:5, 1049-1061. doi: https://doi.org/10.2112/JCOASTRES-D-12-00162.1.
Trowbridge, P. (2007). Hydrological Parameters for New Hampshire's Estuaries. PREP Reports \& Publications. 130. Available at: https://scholars.unh.edu/prep/130.

U.S. Army Corps of Engineers. (USACE, 2001). HEC-RAS: River Analysis System, User's manual. https://www.hec.usace.army.mil/software/hec-ras/.

U.S. Army Corps of Engineers. (USACE, 2008). HEC-HMS: Hydrologic Modeling System, User's Manual. https://www.hec.usace.army.mil/software/hec-hms/

U.S. Army Corps of Engineers. (USACE, 2009a). Engineer Circular 1165-2-211: Water Resource Policies and Authorities; Incorporating Sea-Level Change Considerations in Civil Works Programs. Available at: https://planning. erdc.dren.mil/toolbox/library/ECs/EC1165-2-211_1Jul2009.pdf.

U.S. Army Corps of Engineers. (USACE, 2009b). HEC-GeoHMS Geospatial; Hydrologic Modeling Extension User's Manual. https://www.hec.usace.army.mil/software/hec-geohms/.

U.S. Army Corps of Engineers. (USACE, 2015). North Atlantic Coast Comprehensive Study: Resilient Adaptation to Increasing Risk, Main Report, U.S. Army Corps of Engineers, pp. 216. Available at: https://usace. contentdm.oclc.org/digital/collection/p266001coll1/id/2793/.

U.S. Fish and Wildlife Service. (USFWS, 2001). National Wetlands Inventory. Available at: http://www.granit.unh.edu/data/search?dset=nwi\&\#47;nh.

U.S. Interagency Advisory Committee on Water Data. (USIAC, 1982). Guidelines for Determining Flood Flow Frequency, Bulletin 17-B of the Hydrology Subcommittee: Reston, Virginia, U.S. Geological Survey, Office of Water Data Coordination. 183 pp. Available at: https://water.usgs.gov/osw/bulletin17b/dl_flow.pdf.

Valle-Levinson, A., Dutton, A., \& Martin, J.B. (2017). Spatial and Temporal Variability of Sea Level Rise Hot Spots Over the Eastern United States. Geophysical Research Letters, 44:15, 7876-7882. doi: https://doi.org/10.1002/2017GL073926.

van Vuuren, D.P., Edmonds, J., Kainuma, M., Riahi, K., Thomson, A., Hibbard, K., Hurtt, G.C.,..., \& Rose, S.K. (2011). The Representative Concentration Pathways: An Overview. Climatic Change, 109:5, 5-31. doi: https://doi.org/10.1007/s10584-011-0148-z.

Velicogna, I., Sutterley, T.C., van den Broeke, M.R. (2014), Regional Acceleration In Ice Mass Loss From Greenland And Antarctica Using GRACE TimeVariable Gravity Data. Geophysical Research Letters, 41:22, 8130-8137. doi: https://doi.org/10.1002/2014GL061052.

Villarini, G. \& Smith, J.A. (2010). Flood Peak Distributions for the Eastern United States. Water Resources Research, 46, W06504. doi: https://doi.org/10.1029/2009WR008395.

Wahl, T., Jain, S., Bender, J., Meyers, S.D., \& Luther, M.E. (2015). Increasing Risk of Compound Flooding from Storm Surge and Rainfall for Major US Cities. Nature Climate Change, 5, 1093 - 1097. doi: https://doi.org/10.1038/nclimate2736. 
Wake, C.P., Burakowski, E., Kelsey, E., Hayhoe, K., Stoner, A., Watson, C., \& Douglas, E. (2011). Climate Change in the Piscataqua/Great Bay Region: Past, Present, and Future. Carbon Solutions New England Report for the Great Bay (New Hampshire) Stewards. Available at:

http://scholars.unh.edu/sustainability/8/.

Wake, C.P., Miller, S., Roseen, R., Scholz, A., Rubin, F., Simpson, M., Sinnott, C., Peterson, J., \& Townson, L. (2013). Assessing the Risk of 100-year Freshwater Floods in the Lamprey River Watershed of New Hampshire Resulting from Changes in Climate and Land Use. PREP Publications. 379. Available at: http://scholars.unh.edu/prep/379.

Wake, C.P., Burakowski, E., Wilkinson, P., Hayhoe, K., Stoner, A., Keeley, C.r \& LaBranche, J. (2014). Climate Change in Southern New Hampshire: Past, Present, and Future. Climate Solutions New England Report, Sustainability Institute at the University of New Hampshire. Available at: http://scholars.unh.edu/sustainability/2/.

Wake, C.P., Grogan, D., Zuidema, S., \& Watts, A. (2017). Projecting Future Changes in Flooding Across New England: More Challenging than You Might Think. NH Water \& Watershed Conference, Plymouth State University, Plymouth, NH. https://campus.plymouth.edu/cfe/ previous-nh-water-watershed-conferences/2017-nh-water-watershedconference/.

Walter, D.A., McCobb, T.D., Masterson, J.P., \& Fienen, M.N. (2016). Potential Effects of Sea-Level Rise on the Depth to Saturated Sediments of the Sagamore and Monomoy Flow Lenses on Cape Cod, Massachusetts: U.S. Geological Survey Scientific Investigations Report 2016-5058, 55 p. doi: https://doi.org/10.3133/sir20165058.

Walters, K.M. \& Babbar-Sebens, M. (2016). Using Climate Change Scenarios to Evaluate Future Effectiveness of Potential Wetlands in Mitigating High Flows in a Midwestern U.S. Watershed, Ecological Engineering, 89, 80102. doi: https://doi.org/10.1016/j.ecoleng.2016.01.014.

WAMDI Group (1988). The WAM Model - A Third Generation Ocean Wave Prediction Model, Journal of Physical Oceanography, 18, 1775-1810. doi: https://doi.org/10.1175/1520-0485(1988)018\%3C1775:TWMTGO\%3 E2.0.CO;2.

Ward, L. \& Adams, J. (2001). A Preliminary Assessment of Tidal Flooding along the New Hampshire Coast: Past, Present and Future. The New Hampshire Office of Emergency Management and the Office of State Planning Coastal Program. Available at: https://scholars.unh.edu/faculty_pubs/649/.

Wilson, K., Kelley, J., Reeve, A., \& Belknap, D. (2012). Morphological Controls on Maine's Salt Marshes: Dynamic Salt Marsh Pools, Groundwater, and SeaLevel Rise, 2012 Annual Meeting of the Geological Society of America, Charlotte Convention Center, Charlotte, North Carolina, Nov 4, 2012.
Wilson, D.J., Bertram, R.A., Needham, E.F., van de Flierdt, T., Welsh, K.J., McKay, R.M., Mazumder, A.,..., \& Escutia, C. (2018). Ice Loss from the East Antarctic Ice Sheet During Late Pleistocene Interglacials. Nature, 561, 381-386. doi: http://doi.org/10.1038/s41586-018-0501-8.

Woldemeskel, F., \& Sharma, A. (2016). Should Flood Regimes Change in a Warming Climate? The Role of Antecedent Moisture Conditions. Geophysical Research Letters, 43, 7556-7563. doi: https://doi.org/10.1002/2016GL069448.

Yin, J. (2012). Century to Multi-Century Sea-Level Rise Projections from CMIP5 Models. Geophysical Research Letters, 39, L17709. doi: https://doi.org/10.1029/2012GL052947.

Yin, J., Schlesinger, M.E., \& Stouffer, R.J. (2009). Model Projections of Rapid Sea-Level Rise on the Northeast Coast of the United States. Nature Geoscience, 2, 262-266. doi: https://doi.org/10.1038/ngeo462.

Yin, J., \& Goddard, P.B. (2013). Oceanic Control of Sea Level Rise Patterns Along the East Coast of the United States. Geophysical Research Letters, 40:20, 5514-5520. doi: https://doi.org/10.1002/2013GL057992.

Zemp, M., Huss, M., Thibert, E., Eckert, N., McNabb, R., Huber, J., Barandun,..., \& Cogley, J.G. (2019). Global Glacier Mass Changes and their Contributions to Sea-Level Rise from 1961 to 2016. Nature, 658, 382-386. doi: https://doi.org/10.1038/s41586-019-1071-0. 


\section{APPENDIX A}

Table 4.2.B. Decadal relative sea-level rise (RSLR) estimates (in feet) above 2000 levels for NH based on K14 projections for the stabilized greenhouse gas concentration scenario (RCP 4.5) and the Seavey Island tide gauge record.

\begin{tabular}{|c|c|c|c|c|c|c|}
\hline Year & Central Estimate & Likely Range & 1-in-20 Chance & 1-in-100 Chance & 1-in-200 Chance & $\begin{array}{c}1 \text {-in-1000 } \\
\text { Chance }\end{array}$ \\
\hline & $\begin{array}{l}\text { 50\% probability } \\
\text { SLR meets or } \\
\text { exceeds: }\end{array}$ & $\begin{array}{l}67 \% \text { probability } \\
\text { SLR is between: }\end{array}$ & $\begin{array}{l}\text { 5\% probability } \\
\text { SLR meets or } \\
\text { exceeds: }\end{array}$ & $\begin{array}{l}\text { 1\% probability } \\
\text { SLR meets or } \\
\text { exceeds: }\end{array}$ & $\begin{array}{l}\text { 0.5\% probability } \\
\text { SLR meets or } \\
\text { exceeds: }\end{array}$ & $\begin{array}{l}\text { 0.1\% probability } \\
\text { SLR meets or } \\
\text { exceeds: }\end{array}$ \\
\hline 2030 & 0.5 & $0.3-0.7$ & 0.9 & 1.0 & 1.1 & 1.3 \\
\hline 2040 & 0.7 & $0.4-1.0$ & 1.2 & 1.5 & 1.6 & 2.0 \\
\hline 2060 & 1.1 & 0.7-1.6 & 2.1 & 2.6 & 3.0 & 3.8 \\
\hline 2070 & 1.4 & $0.8-2.0$ & 2.5 & 3.3 & 3.7 & 4.9 \\
\hline 2080 & 1.5 & $0.9-2.3$ & 3.0 & 3.9 & 4.5 & 6.0 \\
\hline 2120 & 2.3 & $1.1-3.6$ & 4.9 & 7.0 & 8.3 & 12.0 \\
\hline 2130 & 2.4 & $1.2-3.9$ & 5.4 & 7.9 & 9.3 & 13.8 \\
\hline 2140 & 2.6 & $1.2-4.3$ & 5.9 & 8.9 & 10.5 & 15.9 \\
\hline 2150 & 2.7 & $1.2-4.6$ & 6.4 & 9.9 & 11.7 & 18.1 \\
\hline
\end{tabular}

